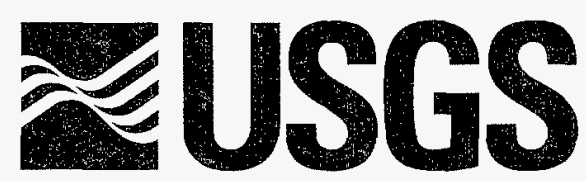

science for a changing world

\title{
CHARACTERIZATION OF HYDROGEOLOGIC UNITS USING MATRIX PROPERTIES, YUCCA MOUNTAIN, NEVADA
}

U.S. GEOLOGICAL SURVEY

Water-Resources Investigations Report 97-4243

\section{PECENED \\ MAY 1$\}$ 1988 \\ OSTI}

Prepared in cooperation with the

NEVADA OPERATIONS OFFICE,

U.S. DEPARTMENT OF ENERGY, under

Interagency Agreement DE-AI08-92NV10874

DTIC QUALITY INBPECTED 1

DISTREBUTION STATEMEITI

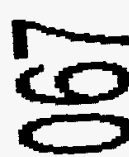

Approved for public release; 


\section{DISCLAIMER}

This report was prepared as an account of work sponsored by an agency of the United States Government. Neither the United States Government nor any agency thereof, nor any of their employees, makes any warranty, express or implied, or assumes any legal liability or responsibility for the accuracy, completeness, or usefulness of any information, apparatus, product, or process disclosed, or represents that its use would not infringe privately owned rights. Reference herein to any specific commercial product, process, or service by trade name, trademark, manufacturer, or otherwise does not necessarily constitute or imply its endorsement, recommendation, or favoring by the United States Government or any agency thereof. The views and opinions of authors expressed herein do not necessarily state or reflect those of the United States Government or any agency thereof. 


\section{CHARACTERIZATION OF HYDROGEOLOGIC UNITS USING MATRIX PROPERTIES, YUCCA MOUNTAIN, NEVADA}

by Lorraine E. Flint

U.S. GEOLOGICAL SURVEY

Water-Resources Investigations Report 97-4243

Prepared in cooperation with the

NEVADA OPERATIONS OFFICE,

U.S. DEPARTMENT OF ENERGY, under

Interagency Agreement DE-Al08-92NV10874

DISTRIBUTION OF THIS DOCUNENT IS UNLMITED ph MASTER 


\title{
U.S. DEPARTMENT OF THE INTERIOR BRUCE BABBITT, Secretary
}

\author{
U.S. GEOLOGICAL SURVEY
}

Thomas J. Casadevall, Acting Director

The use of firm, trade, and brand names in this report is for identification purposes only and does not constitute endorsement by the U.S. Geological Survey.

For additional information write to:

Chief, Earth Science Investigations Program Yucca Mountain Project Branch U.S. Geological Survey Box 25046, Mail Stop 421

Denver Federal Center Denver, CO 80225-0046
Copies of this report can be purchased from:

U.S. Geological Survey Information Services

Box 25286

Federal Center

Denver, CO 80225 


\section{CONTENTS}

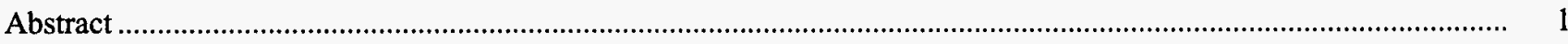

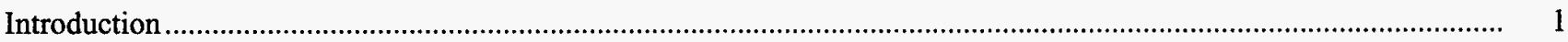

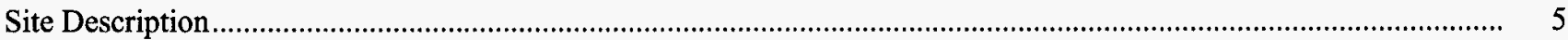

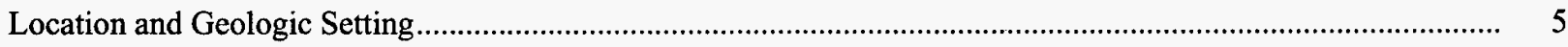

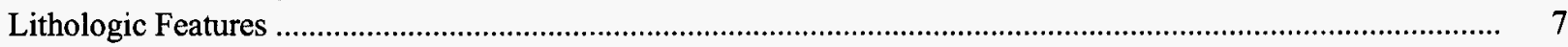

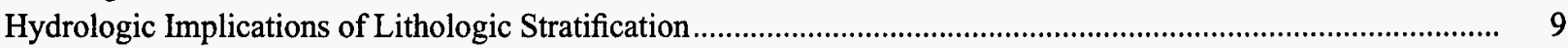

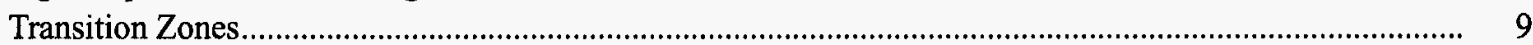

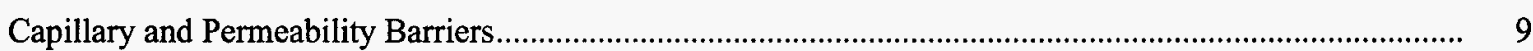

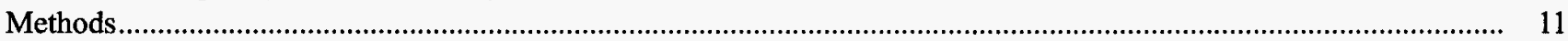

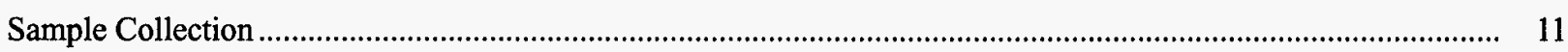

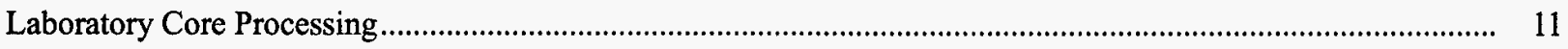

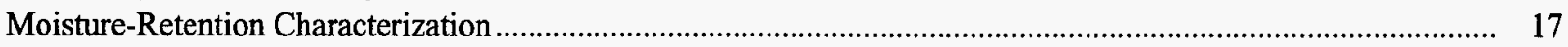

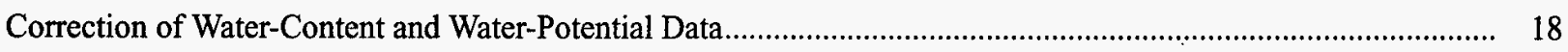

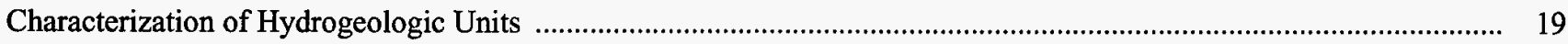

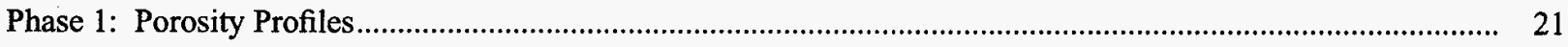

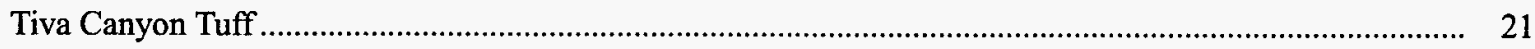

Nonwelded Paintbrush Tuff and Base of Tiva Canyon Tuff.................................................................... 21

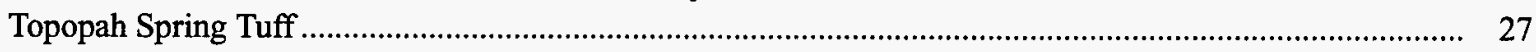

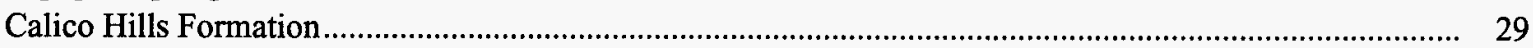

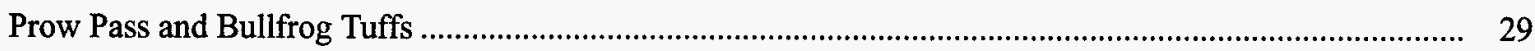

Phase 2: Alteration, Microfractures, and Permeability ............................................................................. 32

Phase 3: Moisture Retention and Predictions of Field Water Potentials............................................................ 40

Phase 4: Statistical Analysis to Produce Mean Values for Modeling Parameters ................................................ 43

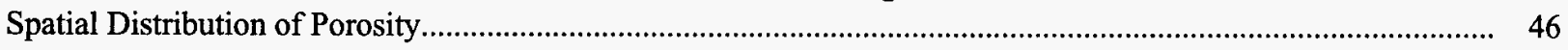

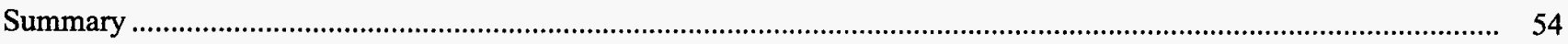

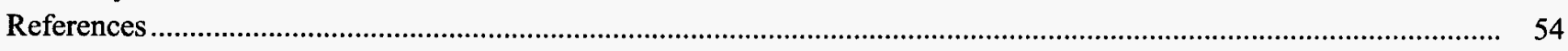

Appendix: Frequency Distributions of Porosity for Hydrogeologic Units ............................................................ 59

\section{FIGURES}

1. Map of study site with locations of boreholes used to develop matrix properties data set and hydrogeologic units.

2. Diagram of the steps used to process core samples to obtain hydrologic property measurements ......................... 16

3. Porosity, saturation, particle density, and water potential with calculated no-flow conditions in equilibrium with the water table, with depth for borehole SD7

4. Porosity, saturation, particle density, and water potential with calculated no-flow conditions in equilibrium with the water table, with depth for borehole SD9.

5. Oven-dry porosity and saturation profiles for rocks from the upper part of the Tiva Canyon Tuff in boreholes $\mathrm{N} 36$ and $\mathrm{N} 27$

6. Oven-dry porosity and saturation profiles for rocks between the lower part of the Tiva Canyon Tuff, bedded tuffs of the Paintbrush Group, Yucca Mountain and Pah Canyon Tuffs, and the upper part of the Topopah Spring Tuff for boreholes SD7, N54, and N55

7. Oven-dry porosity and saturation profiles for rocks from the Paintbrush Group between the lower Tiva Canyon Tuff and upper Topopah Spring Tuff in boreholes N31 and SD9

8. Oven-dry porosity and saturation profiles of rocks from the Topopah Spring Tuff in boreholes UZ14, $\mathrm{UZ16}$, and SD7 
9. Oven-dry porosity and saturation profiles of rocks from the base of the Topopah Spring Tuff; the pre-Topopah Spring bedded tuff; the Calico Hills Formation; and the Prow Pass, Bullfrog and Tram Tuffs of the Crater Flat Group from boreholes SD9, UZ16, and SD7

10. Porosity determined using standard oven drying and relative humidity oven drying for core from the Calico Hills Formation, Prow Pass Tuff, and part of the Bullfrog Tuff in SD7 and for core from the lower part of the Tiva Canyon Tuff to the upper part of the Topopah Spring Tuff in borehole N31

11. Calculated particle density using water saturation versus particle density measured using helium pycnometry for nonwelded to densely welded tuffs that are vitric, crystallized, or zeolitized on samples from borehole UZ16.

12. Relation of porosity and saturated hydraulic conductivity for samples grouped (a) by various hydrogeologic units and (b) by vitric/crystallized, altered, and microfractured units

13. Moisture-retention curves for core samples from hydrogeologic units (a) CW, (b) BT3, (c) TR, (d) TUL, (e) TMN, (f) PV3, (g) CHZ, and (h) PP2.

14. Relation of log of moisture-retention curve-fit parameter, van Genuchten alpha, to porosity.....

15. Measured (squares) and estimated (circles) water potential using moisture-retention parameters for boreholes SD7, SD9, and UZ14

16. Contour plots of the spatial distribution of porosity for hydrogeologic units (a) $\mathrm{CW}$, using 17 boreholes, and (b) BT2, using 15 boreholes

\section{TABLES}

1. Generalized lithostratigraphy (modified from Buesch and others, 1996b; Moyer and Geslin, 1995), previously used informal nomenclature (modified from Scott and Bonk, 1984), and corresponding major units (Montazer and Wilson, 1984) and detailed hydrogeologic units at Yucca Mountain, Nevada.....

2. Data tracking numbers for all data used.....

3. Borehole descriptions, locations, and drilling dates

4. Generalized lithostratigraphy of eight deep boreholes

5. Generalized lithostratigraphy of 23 neutron boreholes

6. Regression equations used to predict saturated hydraulic conductivity and moisture-retention curve-fit parameter, $\alpha$, from porosity values and standard deviation

7. Mean values and standard devit
each hydrogeologic unit

8. Moisture-retention van Genuchten curve-fit parameters, alpha and $\mathrm{n}$, for each hydrogeologic unit

9. Mean porosity, saturation, and standard deviations for each hydrogeologic unit in each borehole. 


\section{CONVERSION FACTORS}

\begin{tabular}{rll}
\hline Multiply & By & To obtain \\
micrometer $(\mu \mathrm{m})$ & & \\
centimeter $(\mathrm{cm})$ & 0.0394 & inch \\
inch \\
centimeter squared $\left(\mathrm{cm}^{2}\right)$ & 0.3937 & inch squared \\
cubic centimeter $\left(\mathrm{cm}^{3}\right)$ & 0.1550 & cubic inch \\
cubic centimeter per cubic & 0.0610 & cubic inch per cubic inch \\
centimeter $\left(\mathrm{cm}^{3} / \mathrm{cm}^{3}\right)$ & & pound per cubic inch \\
feter $(\mathrm{m})$ & 1.0000 & feet \\
feet per second \\
gram per cubic centimeter $\left(\mathrm{g} / \mathrm{cm}^{3}\right)$ & 0.0361 & feet per second \\
meter per second $(\mathrm{m} / \mathrm{s})$ & 3.2810 & mile \\
millimeter per year $(\mathrm{mm} / \mathrm{yr})$ & 3.2810 & square mile \\
kilometer $(\mathrm{km})$ & $1 \times 10^{-10}$ & bars \\
square kilometer $\left.(\mathrm{km})^{2}\right)$ & 0.6214 & 0.3861 \\
megapascals $(\mathrm{MPa})$ & 10.0 & \\
\hline
\end{tabular}

Degree Celsius $\left({ }^{\circ} \mathrm{C}\right)$ may be converted to degree Fahrenheit $\left({ }^{\circ} \mathrm{F}\right)$ by using the following equation:

$$
{ }^{\circ} \mathrm{F}=9 / 5\left({ }^{\circ} \mathrm{C}\right)+32 .
$$

Degree Fahrenheit $\left({ }^{\circ} \mathrm{F}\right)$ may be converted to degree Celsius $\left({ }^{\circ} \mathrm{C}\right)$ by using the following equation:

$$
{ }^{\circ} \mathrm{C}=5 / 9\left({ }^{\circ} \mathrm{F}-32\right) \text {. }
$$




\title{
Characterization of Hydrogeologic Units Using Matrix Properties, Yucca Mountain, Nevada
}

\author{
By Lorraine E. Flint
}

\section{ABSTRACT}

Determination of the suitability of Yucca Mountain, in southern Nevada, as a geologic repository for high-level radioactive waste requires the use of numerical flow and transport models. Input for these models includes parameters that describe hydrologic properties and the initial and boundary conditions for all rock materials within the unsaturated zone, as well as some of the upper rocks in the saturated zone. There are 30 hydrogeologic units in the unsaturated zone, and each unit is defined by limited ranges where a discrete volume of rock contains similar hydrogeologic properties. These hydrogeologic units can be easily located in space by using three-dimensional lithostratigraphic models based on relationships of the properties with the lithostratigraphy. Physical properties of bulk density, porosity, and particle density; flow properties of saturated hydraulic conductivity and moisture-retention characteristics; and the state variables (variables describing the current state of field conditions) of saturation and water potential were determined for each unit. Units were defined using (1) a data base developed from 4,892 rock samples collected from the coring of 23 shallow and 8 deep boreholes, (2) described lithostratigraphic boundaries and corresponding relations to porosity, (3) recognition of transition zones with pronounced changes in properties over short vertical distances, (4) characterization of the influence of mineral alteration on hydrologic properties such as permeability and moisture-retention characteristics, and (5) a statistical analysis to evaluate where boundaries should be adjusted to minimize the variance within layers. This study describes the correlation of hydrologic properties to porosity, a property that is well related to the lithostratigraphy and depositional and cooling history of the volcanic deposits and can, therefore, be modeled to be distributed laterally. Parameters of the hydrogeologic units developed in this study and the relation of flow properties to porosity that are described can be used to produce detailed and accurate representations of the core-scale hydrologic processes ongoing at Yucca Mountain.

\section{INTRODUCTION}

Characterization of physical and hydrologic properties of subsurface materials is critical to the evaluation of sites for land-use practices, such as landfills, radioactive waste burial, regeneration of deforested sites, and agriculture. These practices all have in common the need to understand subsurface hydrology in terms of the water balance of the system and transport of chemicals through subsurface horizons, whether saturated or unsaturated. Predictions of water flow and contaminant transport pathways and flux rates are major issues facing many land managers and environmental researchers and often require the use of numerical models. These models generally require input of parameters describing physical and flow properties of the media, geometry of the modeling domain, and initial and boundary conditions. In addition, subsurface processes, such as perched water, preferential flow paths, or lateral diversion of water, which are influenced by features, such as faults, fractures, or abrupt changes in lithology, can also be understood through characterizing the properties of the media. Numerous researchers have measured hydrologic properties of the tuffs at Yucca Mountain (Anderson, 1981a,b, 1984, 1991; Rush and others, 1983; Thordarson and others, 1984; Weeks and Wilson, 1984; Whitfield and others, 1984; Whitfield and others, 1993; Peters and others, 1984; Peters and others, 1987; Klavetter and Peters, 1987; Flint and Flint, 1990; Kume and Hammermeister, 1990; Nelson and others, 1991; Rautman, 1991; Loskot and Hammermeister, 1992; Loskot, 1993; Rautman and others, 1995; Flint and others, 1996b). This study is being conducted in cooperation with the U.S. Department of Energy to provide a consistent and repeatable framework based on samples collected and methodology 
performed following an approved quality-assurance program for the purpose of site characterization.

The site being characterized in this study is Yucca Mountain, a potential location for a geologic repository for high-level radioactive waste. Yucca Mountain is located in southern Nevada within the southern Nevada volcanic field and is underlain by a thick sequence of volcanic rocks of Miocene age with numerous variations in lithostratigraphy and orientation of the layered Tertiary volcanic sequence (Scott and Bonk, 1984; Buesch and others, 1996a). The processes of eruption and deposition, including the cooling and crystallization of some deposits, and the postdepositional processes of alteration and tectonics all contribute to the distribution of volcanic rock types. Knowledge of these processes is critical to understanding variations in the distribution of hydrologic and physical properties in the unsaturated zone at this site. Lithostratigraphic units are based on depositional, welding, crystallization, alteration, and fracture characteristics (Buesch and others, 1996b; Moyer and Geslin, 1995), as well as variations in hydrogeologic properties such as bulk density, grain density, porosity, and permeability (Scott and others, 1983; Flint and Flint, 1990; Moyer and others, 1996). These properties correlate well in many cases with lithostratigraphic features such as welding, vitrification, and mineralogy (Rautman and Flint, 1992; Istok and others, 1994; Flint and others, 1996b; Moyer and others, 1996).

Descriptions of lithostratigraphic units (Geslin and others, 1995; Geslin and Moyer, 1995; Moyer and Geslin, 1995; Moyer and others, 1995; Buesch and others, 1996b; Engstrom and Rautman, 1996; Rautman and Engstrom, 1996a, 1996b) and the properties measured during this study were used to develop distinct hydrogeologic units with associated mean values of physical properties and hydrologic parameters that can be used in numerical modeling. Hydrogeologic-unit designations have been historically confined to large unit divisions based primarily on degree of welding (Scott and others, 1983; Montazer and Wilson, 1984). Montazer and Wilson (1984) grouped rocks into five hydrogeologic units (table 1): the Tiva Canyon welded, Paintbrush nonwelded, Topopah Spring welded, Calico Hills nonwelded, and the Crater Flat variably to nonwelded units.

The purpose of this report is to provide a more detailed division of the rocks at Yucca Mountain. Being able to define most of the hydrogeologic boundaries from lithostratigraphic boundaries was a major consideration in order to be able to spatially distribute the properties for any modeling effort with the use of the three-dimensional lithostratigraphic framework model produced by the U.S. Geological Survey (USGS) (Buesch and others, 1996b). To provide reasonable detail and predictive ability within the magnitude and heterogeneity of the Yucca Mountain site and to allow for detailed process modeling as well as largescale three-dimensional modeling, the number of distinct vertical layers was limited and resulted in a total of 30. Relations of modeling parameters to porosity are also presented to provide the means by which even more detailed process models can be constructed; for example, through the scaling of parameters in transitional zones where properties change dramatically over short distances or in clay-altered or vapor-phase corroded zones.

The Yucca Mountain site provides several challenges to understanding the distribution and modeling of physical properties and hydrologic parameters due to the depositional, cooling, and alteration history of the rocks. This history results in differences in porosity, connectivity and tortuosity of flow paths, waterretention character, vertical heterogeneities, and various scales of features that all influence the resulting hydrogeology at the site. These characteristics are discussed in detail in various sections of this report. There are 15 rock types that result from variously combining the type of deposition, amount of welding, and composition of grains - either glass, crystallized at high temperature (quartz, feldspar, and vapor-phase minerals), or diagenetically altered (zeolites and clays). Data presented are described within the context of these 15 rock (lithologic) types. In several locations, horizontal boundaries between lithostratigraphic and hydrogeologic units are distinctly abrupt. These contacts need to be modeled as distinct boundaries to promote the appropriate modeled hydrologic responses, such as lateral diversion due to capillary barrier or permeability barrier effects (Montazer and Wilson, 1984). In other locations, the transitional zones also need to be modeled appropriately so that, for example, abrupt discontinuities in modeling matrix properties do not result in unwarranted diversion or ponding of water where discontinuities do not actually exist (Moyer and others, 1996), but where the change in properties is, in reality, gradual or smooth. Alteration of glass to clays and zeolites has occurred in several lithostratigraphic locations. These alterations are due to (1) transitions in lithology that have resulted in high saturations, (2) an 
Table 1. Generalized lithostratigraphy (modified from Buesch and others, 1996b; Moyer and Geslin, 1995), previously used informal nomenclature (modified from Scott and Bonk, 1984), and corresponding major units (Montazer and Wilson, 1984) and detailed hydrogeologic units at Yucca Mountain, Nevada

$[<$, less than; > greater than; $\%$, percentage of matrix porosity $]$

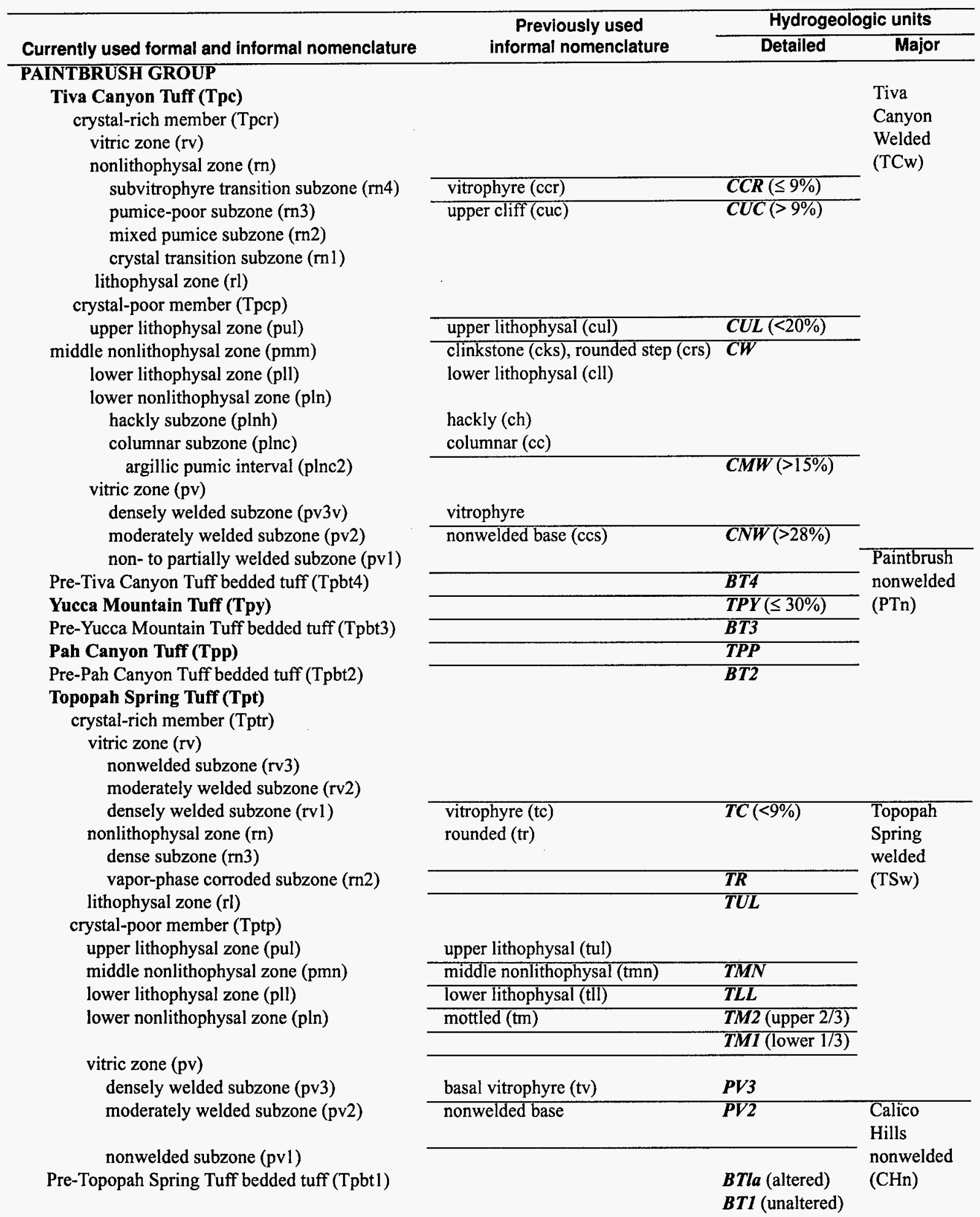


Table 1. Generalized lithostratigraphy (modified from Buesch and others, 1996b; Moyer and Geslin, 1995), previously used informal nomenclature (modified from Scott and Bonk, 1984), and corresponding major units (Montazer and Wilson, 1984) and detailed hydrogeologic units at Yucca Mountain, Nevada--Continued

[ $<$, less than; > greater than; $\%$, percentage of matrix porosity]

\begin{tabular}{|c|c|c|c|c|}
\hline \multirow{2}{*}{\multicolumn{2}{|c|}{ Currently used formal and informal nomenclature }} & \multirow{2}{*}{$\begin{array}{l}\text { Previously used } \\
\text { informal nomenclature }\end{array}$} & \multicolumn{2}{|c|}{ Hydrogeologic units } \\
\hline & & & Detailed & Major \\
\hline \multicolumn{5}{|c|}{ CALICO HILLS FORMATION (Tac) } \\
\hline Unit 4 & Pumiceous pyroclastic flow & Calico Hills vitric $(\mathrm{CHv})$ & $C H V$ (vitric) & \multirow{13}{*}{$\begin{array}{l}\text { Calico } \\
\text { Hills } \\
\text { nonwelded } \\
(\mathrm{CHn})\end{array}$} \\
\hline Unit 3 & Lithic-rich pyroclastic flow & Calico Hills zeolitized $(\mathrm{CHz})$ & $C H Z$ (zeolitic) & \\
\hline Unit 2 & Pumiceous pyroclastic flow & & & \\
\hline Unit 1 & Lithic-rich pyroclastic flow & & & \\
\hline \multirow{2}{*}{\multicolumn{2}{|c|}{$\begin{array}{l}\text { Bedded tuff (Tacbt) } \\
\text { Basal sandstone (Tacbs) }\end{array}$}} & & $\overline{B T}$ & \\
\hline & & & & \\
\hline \multicolumn{4}{|c|}{ CRATER FLAT GROUP } & \\
\hline \multicolumn{4}{|c|}{ Prow Pass Tuff (Tcp) } & \\
\hline Unit 4 & Pyroxene rich & & PP4 (zeolitic) & \\
\hline \multirow[t]{2}{*}{ Unit 3} & Welded pyroclastic flow & & $\overline{\boldsymbol{P P 3} \text { (devitrified) }}$ & \\
\hline & & & $\overline{P P 2}$ (devitrified) & \\
\hline Unit 2 & Lithic-rich pyroclastic flow & & $\overline{P P 1}$ (zeolitic) & \\
\hline Unit 1 & Pumiceous pyroclastic flow & & & \\
\hline \multicolumn{5}{|c|}{ Pre-Prow Pass bedded tuff (Tcpbt) } \\
\hline \multicolumn{2}{|c|}{ Bullfrog Tuff (Tcb) } & & BF3 (welded) & Crater Flat \\
\hline \multicolumn{2}{|c|}{ Unit 4} & & & $(\mathrm{CFu})$ \\
\hline \multicolumn{5}{|l|}{ Unit 3} \\
\hline \multicolumn{2}{|l|}{ Unit 2} & & $\overline{B F 2}$ (nonwelded) & \\
\hline \multicolumn{5}{|c|}{ Unit 1} \\
\hline \multicolumn{5}{|c|}{ Pre-Bullfrog Tuff basal sandstone (Tcbbs) } \\
\hline Tram Tuf & (Tet) & & & \\
\hline
\end{tabular}


ancient water table or perched water zones, (3) weathering at the surface of ash flows, or (4) local cooling in welded tuffs (Levy, 1984; Broxton and others, 1987; Bish and Aronson, 1993; Buesch and others, 1995; Levy and others, 1996). In the upper, crystal-rich zones of both of the major pyroclastic flow units, varying degrees of vapor-phase corrosion have occurred that also change the properties with depth. Vaporphase corrosion also occurs in the rocks of the Crater Flat Group and, to a lesser degree, in the Yucca Mountain and Pah Canyon Tuffs (table 1).

When characterizing matrix properties, one attempts to describe the heterogeneous rocks with features of various scales. For the purpose of numerical modeling on all scales, the measurement of matrix properties describes small centimeter-scale features, but the description of hydrogeologic units is based on much larger scale features, such as bulk permeability. Scale differences are attributed mainly to the presence of fractures that vary from less than a micrometer to hundreds of micrometers in aperture and may or may not be stratibound (not extending across lithostratigraphic unit boundaries). This study is based on the measurements of rock properties from 7-centimeter (cm)-diameter core samples collected during the drilling of boreholes. Thus, it is limited to features and properties that can be captured on a relatively small scale. Many properties that characterize the matrix of the rock unit are adequately represented by analyses on this scale (McKenna and Rautman, 1996), but even this scale of core sample has heterogeneities that may be captured or omitted in the sampling or measurement phases. Alteration, microfractures, and even porosity occur variably within the rocks at the core scale. Some matrix properties are indicative of larger scale features, such as the increase in matrix porosity that is measured in lithophysal zones. On the other hand, many larger scale processes and features, such as the bulk properties of lithophysal cavities, fractures, and faults, will not be adequately represented. Based on some of the scale-dependent relations described herein, it is encouraged that modeling efforts be designed to acknowledge different scales of the hydrologic system to provide more insight into the mechanisms and processes that exist in the field. The scope of this study does not include characterization of the lateral distributions of rock properties, which is being much more rigorously addressed by other researchers (Rautman, 1995). Rather, this study introduces the relation of hydrologic properties to porosity and provides model parameter values for the rock units determined to be hydrologically distinct.

Laboratory assistance and data analysis were provided by Jenny Curtis, Cara Vidano, and Greg Mongano, all of Foothill Engineering Corp., and Mike Spychala of Sandia National Laboratories. Alan Flint is gratefully acknowledged for insight provided during the methods development and data interpretation, as well as the time and effort contributed to the collection and laboratory processing of core samples for this large data set. David Buesch provided valuable insight into the relations of properties to lithostratigraphy. This work was performed by the U.S. Geological Survey for the U.S. Department of Energy, Office of Civilian Radioactive Waste Management, Yucca Mountain Site Characterization Project Office under contract DE-AI08-92NV10874.

\section{SITE DESCRIPTION}

\section{Location and Geologic Setting}

Yucca Mountain is 145 kilometers $(\mathrm{km})$ northwest of Las Vegas, Nevada (fig. 1), in a climatic transitional zone between the Mojave and Great Basin Deserts in the Basin and Range physiographic province (Grayson, 1993). It is in the rain shadow of the Sierra Nevada, which results in an arid climate, with average annual precipitation of approximately 165 millimeters per year (mm/yr) (Flint and others, 1996). In the general vicinity of Yucca Mountain, middle Miocene sedimentary deposits are overlain by a thick sequence of rhyolitic lavas and pyroclastic deposits that were deposited from 14 to 9.5 million years ago (Ma) (Sawyer and others, 1994) and that cover an extensive area of about 13,000 square kilometers $\left(\mathrm{km}^{2}\right)$, known as the southern Nevada volcanic field (Byers and others, 1976). Many of the volcanic deposits within this field do not have identified source areas, but several came from source areas within a group of calderas known as the Timber Mountain-Oasis Valley caldera complex (Byers and others, 1976; Sawyer and others, 1994). 


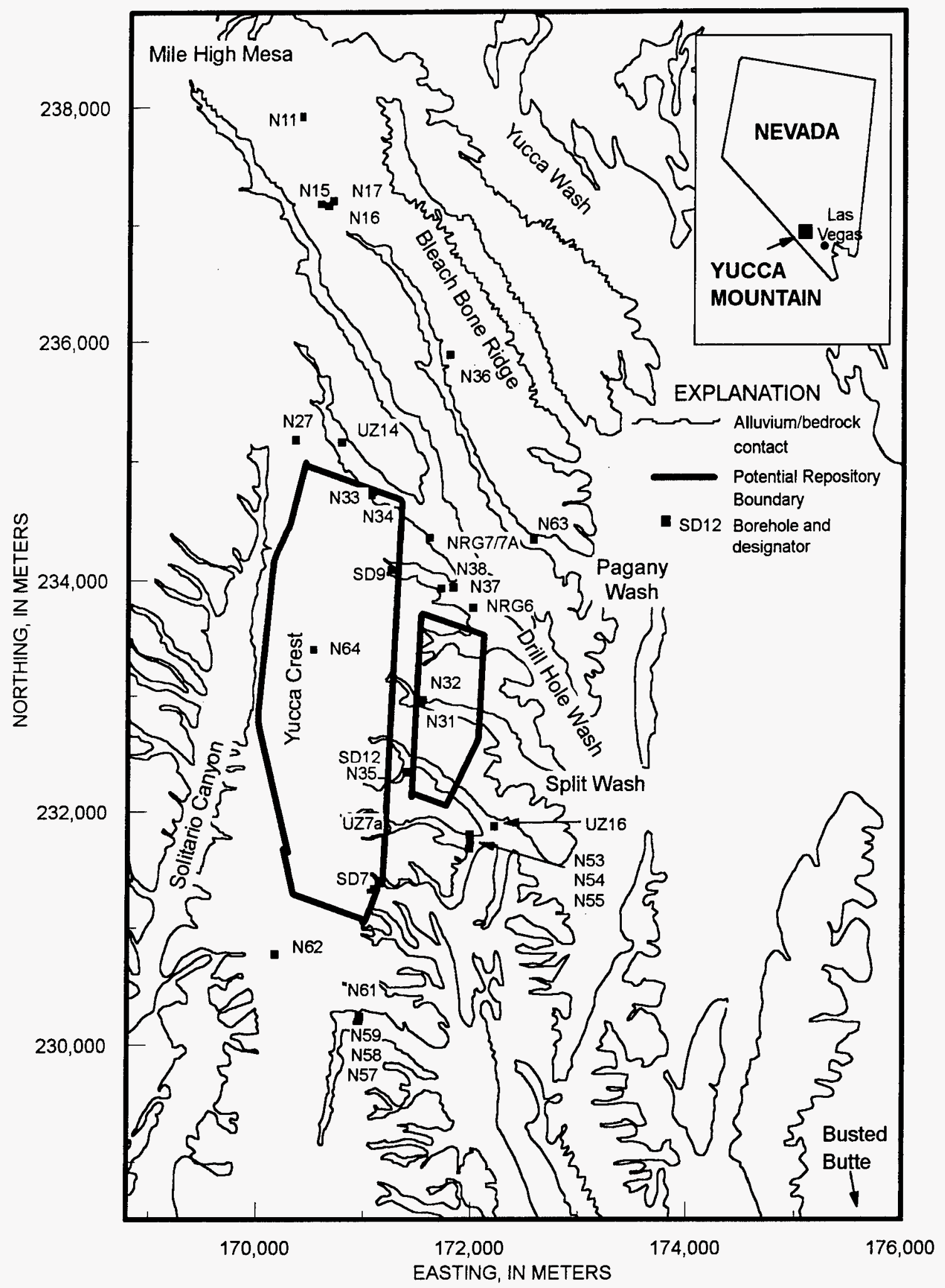

Figure 1. Map of study site with locations of boreholes used to develop matrix properties data set and hydrogeologic units. 
At Yucca Mountain, which is located directly south of the caldera complex, geophysical evidence (Snyder and Carr, 1982; Nelson and others, 1991; Nelson, 1994) and borehole investigations (Buesch and others, 1996a) indicate that the Tertiary volcanic sequence varies in thickness between 1 and $3 \mathrm{~km}$ with an unsaturated zone that is approximately 500 to 750 meters $(\mathrm{m})$ thick. The formations in the unsaturated zone at Yucca Mountain consist primarily of pyroclastic flow deposits. From youngest to oldest, they are the Rainier Mesa Tuff of the Timber Mountain Group; the Tiva Canyon, Yucca Mountain, Pah Canyon, and Topopah Spring Tuffs of the Paintbrush Group; the Calico Hills Formation; and the Prow Pass, Bullfrog, and Tram Tuffs of the Crater Flat Group (table 1) (Carr and others, 1986; Sawyer and others, 1994). Interstratified with the formations are bedded tuffs that consist primarily of fallout tephra deposits with minor amounts of pyroclastic flow deposits and redeposited material (Diehl and Chornack, 1990; Moyer and Geslin, 1995; Buesch and others, 1996b). The Tiva Canyon and Topopah Spring Tuffs contain vitric, nonwelded to densely welded tuff at the top and bottom and thick, crystallized, moderate to densely welded and fractured interiors. Regionally, these are compound cooling units, but at Yucca Mountain, they appear to be single cooling units (D.C. Buesch and R.W. Spengler, U.S. Geological Survey, written commun., 1996). Most lithostratigraphic units in the Tiva Canyon and Topopah Spring Tuff are laterally continuous and stratiform although a few units thin and amalgamate northward as they conform to the underlying topography of older rocks (Scott and Bonk, 1984; Buesch and others, 1996b; D.C. Buesch and R.W. Spengler, U.S. Geological Survey, written commun., 1996; W.C. Day, U.S. Geological Survey, written commun., 1996). The Yucca Mountain and Pah Canyon Tuffs are relatively thick to the north near Yucca Wash and contain both nonwelded and welded intervals (Scott and Bonk, 1984; Moyer and others, 1996). However, the welded units thin southward near Drill Hole Wash toward the potential repository, and only thin intervals of nonwelded rocks occur in the center of the potential repository block (D.C. Buesch and R.W. Spengler, U.S. Geological Survey, written commun., 1996; Moyer and others, 1996). Despite the significant thickness changes from north to south, some units exhibit consistent physical and hydrologic properties from Pagany Wash south to Busted Butte, as shown with the moderately to nonwelded base of the Tiva Canyon Tuff by Istok and oth- ers (1994). The Calico Hills Formation is composed of nonwelded pyroclastic flow and fallout deposits with minor amounts of redeposited material, and near the north end of Yucca Mountain, there are interstratified rhyolite lava flows (Moyer and Geslin, 1995; D.C. Buesch and R.W. Spengler, U.S. Geological Survey, written commun., 1996). Tuffaceous rocks have been zeolitized at the north end of Yucca Mountain, yet parts of the formation remain vitric toward the south end of the mountain. Only at Busted Butte are vitric tuffaceous rocks of the Calico Hills Formation exposed at the ground surface on or near Yucca Mountain. The Prow Pass Tuff consists of nonwelded to partially welded tuff at the top and bottom, which is typically zeolitized. Only in the southwestern part of Yucca Mountain do these rocks remain vitric, with partially to moderately welded, crystallized tuff in the interior. The Bullfrog and Tram Tuffs were only penetrated by one borehole used in this study; therefore, the Bullfrog Tuff is sparsely characterized and the Tram Tuff is not characterized. Throughout the text, the lithostratigraphic and hydrogeologic unit symbols (table 1) are used.

\section{Lithologic Features}

Characteristics of the pyroclastic flow deposits result from the sequential development of depositional features, zones of welding, and zones of crystallization although in some rocks welding can be coincident with deposition, and crystallization can occur synchronously with welding to inhibit development of welding (Riehle and others, 1995; Buesch and others, 1996b). Welding of a simple cooling unit typically includes nonwelded rocks at the top and bottom with increased welding toward the center of the deposit and laterally from it; thick deposits can have the complete range of welding, but thin deposits can lack the more welded rocks at the center of the unit (Smith, 1960a, b). Crystallization occurs in zones including high-temperature devitrification, vapor-phase crystallization, vaporphase corrosion, and lithophysal and fumarolic alteration and crystallization (Smith, 1960a, b; Buesch and others, 1996b). No fumaroles were sampled in this study and none are discussed. The overlap of depositional and zonal features at Yucca Mountain has resulted in a complex, detailed lithostratigraphy with zones of welding and crystallization variously developed throughout the site in the different tuffs 
(Buesch and others, 1996b). Many rocks are vitric; therefore, these rocks have not undergone crystallization at high temperature to form mostly quartz and feldspar (also commonly referred to as devitrification) or alteration at low temperature to clays and zeolites. Alteration of glass to clays and zeolites typically occurs where porosity is relatively high and water is present for long enough periods of time to provide the necessary reactions. Glass that crystallized at high temperature forms relatively low porosity rocks in which the feldspars can only alter to clays, zeolites, and analcine under high-temperature hydrothermal conditions (Bish and Aronson, 1995). The dominant lowtemperature alteration products at Yucca Mountain are smectite, clinoptilolite, and mordenite, and locally, opal (Bish and Chipera, 1989). The low-temperature alteration potential of any lithologic unit is dependent on (1) rock composition, (2) rock texture, (3) proximity to structure, and (4) water-rock interaction (Broxton and others, 1987; D.C. Buesch and R.W. Spengler, written commun., 1996). High porosity results in large surface area of glass shards in tuffaceous rocks or in highly fractured glass of lava flows. Therefore, the most likely candidates for alteration are high porosity, vitric rocks associated with faults, with perched water or lateral flow horizons, or within ancient or present saturated zones. The vitric/zeolitic boundary of the ancient water table at Yucca Mountain (Broxton and others, 1987; Buesch and others, 1995) can be a distinct boundary, or it can be a transitional zone, where the geometry appears to depend, at least in part, on the hydrologic and lithologic character of the rocks. Based on macroscopic textural and mineralogic evidence (D.C. Buesch and R.W. Spengler, written commun., 1996; Rautman and Engstrom, 1996b), quantitative mineralogy (Smith, 1960a, b; Broxton and others, 1987; Bish and Chipera, 1989; Bish and Aronson, 1993), and data presented herein, it appears that a relatively abrupt boundary occurs where an ancient water table was confined below the Tptpv3 (table 1), or it occurs as a gradational transition across a vertical span of $30-40 \mathrm{~m}$ in the nonwelded tuffs in the Calico Hills Formation, as observed from geophysical logs and core samples from borehole SD7. An additional alteration product within this zone is opal, which is present in many of the units below the Topopah Spring Tuff where ancient water tables produced zeolitic alteration.

Textural and particle-size distribution of fallout tephras and bedded tuffs generally relate to several lithostratigraphic characteristics and hydrogeologic properties (Moyer and others, 1996; Flint and others, 1996b; D.C. Buesch, written commun., 1996) that determine the moisture-retention character and permeability of the rocks. In some cases, however, there are localized regions of argillic and zeolitic alteration within the bedded units that contribute to their hydrologic character (Moyer and others, 1996; Flint and others, 1996b). The nonwelded zones of the flow units generally follow the same lithologic constraints, with their hydrologic character being a function of pore-size distribution and subsequent alteration products.

Generally, all these features influence the hydrologic character of the rock by changing the pathways through which water must pass in order to flow through the rocks. An increase in welding results in a reduction of porosity and permeability. Crystallization is generally related to hydrologic features through the production of secondary porosity by vapor-phase corrosion, which increases the permeability, or by the deposition of crystals through vapor-phase processes, which can reduce the porosity and, therefore, the permeability. Typically, vapor-phase corrosion occurs in the upper, crystal-rich, nonlithophysal zones of both the Tiva Canyon and Topopah Spring Tuffs where vitric, partially to moderately welded rocks are in contact with crystallized, moderately to densely welded rocks (Buesch and others, 1996b). Vapor-phase corrosion also commonly occurs in the lower part of the columnar subzone and the upper part of the vitric, moderately welded subzone of the crystal-poor Tiva Canyon Tuff and is particularly well developed where the vaporphase corrosion has propagated down into the increasingly porous parts of the moderately welded rocks (Buesch and others, 1996b; Moyer and others, 1996). This secondary porosity can result in measurements that are anomalously high compared to those which would be estimated based on textures of welding (Buesch and others, 1996b; Moyer and others, 1996). Vapor-phase crystallization is typically associated with areas of vapor-phase corrosion and within lithophysal cavities and may or may not affect the porosity, depending on the degree of crystallization. Properties of lithophysal cavities, while possibly inferred, cannot be directly measured using core-scale analyses, but on a larger scale, preliminary investigations have shown that lithophysae may act as a mechanism to concentrate volumes of water. As water moves through lithophysal zones, the volume of rock through which the water passes is reduced by the occurrence of cavities, but the water doesn't move into the cavities under unsaturated 
conditions. This results in an increase in the saturation within the matrix in the lithophysal rocks.

Differences in properties that result from whether or not a rock has undergone devitrification are primarily due to the differences in grain density and microfracturing. Vitric rocks are lower in grain density; for rocks with the same porosity, the vitric rocks have a lower bulk density. The densely welded, vitric rocks with very little porosity and extremely low permeability also have a high density of microfractures, which are observable, very small fractures, that transmit water under high saturations. The dimensions of the micro-fractures, and whether they contain alteration products, will determine whether or not they contribute to unsaturated flow; very small fracture apertures, or alteration materials, may support unsaturated flow. Because the matrix permeability of these rocks is so low, it is common to find high saturations due to concentration of water flowing from higher porosity rocks to lower porosity rocks and permeability barrier effects. There are often low-temperature alteration minerals associated with these rocks, but there are also zones with high-temperature alteration materials (Levy, 1996). Devitrified, densely welded rocks have microfractures that are occasionally sampled in core and typically do not contain alteration minerals. These microfractures will probably not contribute to flow under unsaturated conditions.

\section{Hydrologic Implications of Lithologic Stratification}

Based on general volcanologic relations (Scott and others, 1983; Buesch and others, 1996b; Moyer and others, 1996) and geostatistical analyses (Rautman and Flint, 1992), a number of deterministic geologic processes, including magmatic evolution; volcanic eruption, transport, and emplacement; post-emplacement cooling and alteration; and late-stage (diagenetic) alteration, provide an important framework within which hydrologic characterization must take place. These processes can produce a relatively predictable vertical distribution of properties within simple cooling units, which simplifies the prediction of properties at unsampled locations. Lithologic features controlling the measured distribution of water have been noted consistently in boreholes located in the study area and have aided in the determination of mechanisms and processes ongoing in the unsaturated zone. Hydrologic modeling using a detailed vertical distribution of properties displays the importance of the vertical sequence of lithologic features (Flint and others, 1993; Flint and others, 1996a). Several of these distinctive lithologic features are critical in the characterization of water flow at Yucca Mountain, and the characterization of their physical and hydrologic properties are discussed in detail.

\section{Transition Zones}

Transition zones have a pronounced change in matrix properties with depth, typically caused by a change in porosity due to welding or vapor-phase corrosion. Transition zones occur at the top and bottom of the Tiva Canyon and Topopah Spring Tuffs, where the rocks grade from nonwelded to densely welded and locally incorporate changes in porosity due to vaporphase corrosion.

Corresponding to the degree of welding, the fracture density, geometry, and continuity are typically poorly developed in nonwelded tuffs and well developed in the welded rocks. The transition zone from fracture-dominated flow in welded rocks, where saturation is high, to matrix-dominated flow in nonwelded rocks can significantly affect flow. The rapid decrease or increase in porosity (that also corresponds to changes in the degree of fracturing) in these transition zones may lead to the localized concentration or depletion of water.

\section{Capillary and Permeability Barriers}

The concept of a natural capillary barrier is summarized by Montazer and Wilson (1984) as a finegrained layer overlying a coarse-grained layer, where water cannot flow from the smaller pores into the larger pores until the height of water in the overlying layer exceeds a critical height equivalent to the difference in the capillary rise of the two pore sizes. At Yucca Mountain, the potential for this condition occurs when a porous medium, such as the nonwelded rocks of the Paintbrush Group (PTn), is bounded by double-porosity media, such as the welded and fractured rocks of the Tiva Canyon and Topopah Spring Tuffs (Montazer and Wilson, 1984). A capillary barrier could theoretically be present at the top of the nonwelded rocks where finegrained welded rocks overlie coarse-grained nonwelded rocks. A barrier could also be present at the base of the nonwelded rocks where the coarse-grained 
rocks overlie the larger aperture fractures present in the welded rocks. If these conditions exist in the layered, dipping beds at Yucca Mountain, they could potentially result in the lateral diversion of water.

Theoretically, the conditions leading to lateral diversion of water at sloping interfaces are fairly idealized. Analytically, lateral diversion is a function of saturated hydraulic conductivity $\left(K_{s}\right)$, the angle of incline, the flux rate, and the air-entry pressure of the media (Ross, 1990). Ross (1990) showed there are three conditions of flow that result from changing these parameters. To create a capillary barrier with significant diversion capacity, fine-textured media must overlie coarse-textured media with a linear, sloping contact and a low flux rate. The barrier effect is overcome when the saturation is high enough in the overlying layer for the capillary pressure to be less than the underlying air-entry pressure. The barrier exists due to the difference in effective permeability between the fine layer and the coarse layer under unsaturated conditions. These conditions of flow are described in detail in Oldenburg and Pruess (1993).

Ross (1990) developed an idealized, two-dimensional, tilted model that could be solved analytically to describe this phenomenon. The assumptions and approximations that define this idealized system do not preclude its usefulness, but need to be considered when it is applied to a natural system. Two of the prime assumptions and approximations are that all flow is considered steady state and that the downstream boundary can drain infinitely. There are several important conditions that are not considered in the idealized system. These include moisture gradients, which generally are present; nonlinear phenomena, such as finger instabilities (Hillel and Baker, 1988; Steenhuis and others, 1990); and heterogeneities at the contacts or gradational transitions between rock units as observed at Yucca Mountain. Heterogeneities will influence nonlinear phenomena by causing localized increases in saturation and thus reducing the diversion length. Gradational transitions do not provide the necessary contrast in properties to produce lateral diversion. Oldenburg and Pruess (1993) did a study to test the capability of numerical models to adequately describe capillary diversion. The flow system analyzed, however, was chosen to conform to the idealized system developed by Ross (1990). The numerical model was able to simulate results similar to the analytical calculations, including the prediction of significant lateral diversion based on the contrasting properties and low fluxes, but the non-idealized geometry of the natural system with the transitions and heterogeneities observed at the contacts was still not considered.

The reverse condition, when coarse-grained materials overlie fine-grained materials, can also result in lateral diversion due to the lower layer acting as a permeability barrier. This condition occurs in the transition between the coarse-grained PTn and the densely welded, fractured, crystal-rich vitrophyre of the Topopah Spring Tuff (Tptrv1) under less than saturated conditions. In this transition zone, both permeability and capillary barrier effects could be present depending on the degree of saturation and if the apertures of the fractures are larger than the overlying moderately welded rocks. If fractures are open and apertures are larger than the pore sizes of the overlying materials, they will act as a capillary barrier, which will cause lateral diversion. If the overlying materials become saturated enough to initiate fracture flow, then the barrier effects are reduced. If the fractures are filled with alteration materials, then the permeability barrier comes into effect. Because many of these conditions are likely to be concurrent in this transition location, the processes there can be complicated.

Barrier effects control the hydrology by reducing the downward flux of water across contacts or zones and by either perching or laterally diverting water. These conditions are particularly important in vitric rocks. Vitric zones that maintain high saturation due to the capillary or permeability barrier mechanisms for long periods of time can alter to clays, and these clays can increase the contrast in properties and further enhance the effectiveness of the mechanisms. Vitric zones near transitional contacts are, therefore, particularly important to characterize properly for modeling purposes because of the significant control they potentially impose upon the overall hydrology of the unsaturated-zone system. Numerical functions need to be developed to enable the distribution of properties with depth (finitely) over the transitional contacts during the development of numerical flow models. Furthermore, detailed sensitivity modeling needs to be done to determine the optimum size for grid blocks in these zones to properly reflect true conditions and not inappropriately impose contrasts in properties that will inappropriately divert water laterally. 


\section{METHODS}

To assess the character of this large, heterogeneous, three-dimensional site, analyses of physical and hydrologic properties for 4,892 rock-core samples from 31 boreholes were compiled in a data base. This data base includes measurements of porosity, bulk density, particle density, water content, saturated hydraulic conductivity, and moisture-retention characteristics. To provide initial conditions and site calibration data, present-day field moisture and water-potential conditions were included, along with the associated lithostratigraphic units for all samples.

The core samples were collected and processed under a full quality-assurance program (table 2). All samples were analyzed to determine porosity, bulk density, particle density, and water content. Subsets of samples were measured for determination of water potential, saturated hydraulic conductivity, particle density using helium pycnometry, and moistureretention measurements. The location, altitude, drilling dates, and depth for boreholes are listed in table 3 with complete borehole designation. Following table 3, borehole designations will be abbreviated as "N" plus the associated number for neutron boreholes and "UZ," "SD," and "NRG" plus associated number for the deep boreholes, omitting hyphens and "\#" symbols. Long-term water-content measurements in the 23 neutron boreholes 18 to $83 \mathrm{~m}$ in depth are described in detail in Flint and Flint (1995). Five boreholes (the SD boreholes and UZ14 and UZ16) were drilled from the surface to the water table, and three boreholes (UZ7a and the NRG boreholes) did not penetrate the water table. Deep boreholes (table 4) and neutron boreholes (table 5) are shown relative to a lithostratigraphic column to indicate units sampled in each borehole. Boreholes were drilled to investigate a laterally spatial representation of the site (fig. 1).

\section{Sample Collection}

Boreholes were drilled using dry-drilling technology. The neutron boreholes (prefix " $N$ ") were drilled using the ODEX 115 drilling and casing system (Hammermeister and others, 1985). This method uses simultaneous advancement of the casing with the deepening of the hole to minimize the effects of drilling fluids (in this case, air) on the borehole walls. Formation and core moisture conditions are minimally affected, and some of the cuttings produced from drilling fill the small annular spaces between the casing and formation, minimizing the void space. The remaining boreholes were drilled using reverse-circulation dualwall methodology, which also minimally affects formation and core moisture conditions. Both types of drilling provide continuous core sampling. Two core samples approximately $7 \mathrm{~cm}$ in diameter and $10 \mathrm{~cm}$ in length and $20 \mathrm{~cm}$ in length were collected approximately every $0.8 \mathrm{~m}$ during drilling of the boreholes. Intermittent depth segments occurred where core samples were not recovered due to drilling or formation conditions. Samples were typically placed in steel cans at the drill site within 5 minutes of being recovered from the ground to maintain field moisture conditions.

\section{Laboratory Core Processing}

Cores were processed following the steps indicated in figure 2. Cores were removed from the steel cans and divided into approximately two equal parts. One part was immediately placed on a balance to obtain field weight for moisture content and then labeled with permanent ink. The other part was crushed and immediately sealed in a labeled, taped, glass jar. Crushed samples were analyzed within 4 days for water potential by using a laboratory chilledmirror psychrometer (Water Activity Meter, Model CX-2, Decagon Devices, Inc., Pullman, Wash.). The sample chamber of the chilled-mirror psychrometer is $4 \mathrm{~cm}$ in diameter and $1.5 \mathrm{~cm}$ in height. The chamber is filled with the largest chips of the crushed rock that will fit. Measurements of water activity, $A_{w}$, are measured with the psychrometer simultaneously to the measurement of sample temperature using an infrared thermometer. These values are used to calculate water potential, $\psi$, using the Kelvin equation,

$$
\psi=C(T) \ln \left(A_{w}\right)
$$

where $\mathrm{T}$ is temperature in Kelvins, and $\mathrm{C}=4.618$ bars per Kelvin ( $\mathrm{K}$ minus $273.15={ }^{\circ} \mathrm{C}$ ). The resolution of the instrument introduces an error of \pm 1 percent in $A_{w}$ over the entire range of the instrument. This is an error in water potential of 100 percent at 0 bars to 11 percent at -3000 bars. Measurement error due to the calibration of the instrument with salt solutions is considered negligible. 
Table 2. Data tracking numbers for all data used. (Note: All data are qualified.)

Core Properties

\begin{tabular}{|c|c|}
\hline Tracking Number & Title of Technical Data Information Form \\
\hline DTN GS920508312231.012: & $\begin{array}{l}\text { USW UZ-N54 and USW UZ-N55 core analysis: bulk density, porosity, particle density, and in } \\
\text { situ saturation for core dried in } 105^{\circ} \mathrm{C} \text { oven. }\end{array}$ \\
\hline DTN GS930108312231.006: & $\begin{array}{l}\text { USW UZ-N53 core analysis: bulk density, porosity, particle density, and in situ saturation for } \\
\text { core dried in } 105^{\circ} \mathrm{C} \text { oven. }\end{array}$ \\
\hline DTN GS940408312231.004: & $\begin{array}{l}\text { Core analysis of bulk density, porosity, particle density, and in situ saturation for three neutron } \\
\text { boreholes USW UZ-N57, UZ-N61 and UZ-N62. }\end{array}$ \\
\hline DTN GS940108312231.002: & $\begin{array}{l}\text { Core analysis of bulk density, porosity, particle density, and in situ saturation for seventeen neu- } \\
\text { tron boreholes: Data for core dried in RH oven and } 105^{\circ} \mathrm{C} \text { oven for USW UZ-N31, UZ-N32, } \\
\text { UZ-N33, UZ-N34, UZ-N35, UZ-N38, UZ-N58, UZ-N59, UE-25 UZN\#63 and USW UZ-N64; } \\
\text { data for core dried in } 105^{\circ} \mathrm{C} \text { only for USW UZ-N11, UZ-N15, UZ-N16, UZ-N17, UZ-N27, UZ- } \\
\text { N36, and UZ-N37. }\end{array}$ \\
\hline DTN GS940508312231.006: & $\begin{array}{l}\text { Core analysis of bulk density, porosity, particle density, and in situ saturation for borehole UE-25 } \\
\text { UZ\#16. }\end{array}$ \\
\hline DTN GS950608312231.007: & Physical properties and water potentials of core from borehole USW NRG-6 \\
\hline DTN GS950308312231.004: & Physical properties and water potentials of core from borehole USW SD-9 \\
\hline DTN GS950608312231.005: & Physical properties and water potentials of core from borehole USW UZ-14 \\
\hline DTN GS950308312231.003: & UE-25 UZ\#16 pycnometer data \\
\hline DTN GS951108312231.009: & Physical properties, water content, and water potential for borehole USW SD-7 \\
\hline DTN GS951108312231.011: & Physical properties, water content, and water potential for borehole USW UZ-7a \\
\hline DTN GS951108312231.010: & Physical properties and water content for borehole USW NRG-7/7A \\
\hline DTN GS950308312231.002: & Laboratory measurements of bulk density, porosity, and water content for USW SD-12 \\
\hline DTN GS960808312231.004: & $\begin{array}{l}\text { Physical properties, water content, and water potential for lower depths in boreholes USW } \\
\text { SD-12 and USW SD-7 }\end{array}$ \\
\hline
\end{tabular}

Permeability and Moisture-Retention Measurements

\begin{tabular}{l|l}
\hline Tracking Number & \multicolumn{1}{l}{ Title of Technical Data Information Form } \\
\hline DTN GS950608312231.006: & Water permeability of core from SD-9 \\
\hline DTN GS960808312231.002: & $\begin{array}{l}\text { Relative-humidity-calculated porosity measurements on samples from borehole USW SD-9 used } \\
\text { for saturated hydraulic conductivity. }\end{array}$ \\
\hline DTN GS960808312231.001: & $\begin{array}{l}\text { Saturated hydraulic-conductivity measurements and relative-humidity-calculated porosity mea- } \\
\text { surements on samples from boreholes USW UZ-N27 and UE-25 UZ\#16 }\end{array}$ \\
\hline DTN GS950608312231.008: & Moisture retention data from boreholes USW UZ-N27 and UE-25 UZ\#16. \\
\hline DTN GS960808312231.005: & $\begin{array}{l}\text { Water permeability and relative-humidity-calculated porosity measurements on samples from } \\
\text { boreholes USW SD-7, USW SD-9, USW SD-12, and USW UZ-14 }\end{array}$ \\
\hline DTN GS960808312231.003: & $\begin{array}{l}\text { Moisture-retention data for samples from boreholes USW SD-7, USW SD-9, USW SD-12, and } \\
\text { USW UZ-14 }\end{array}$ \\
\hline
\end{tabular}


Table 3. Borehole descriptions, locations, and drilling dates

\begin{tabular}{|c|c|c|c|c|c|c|c|}
\hline $\begin{array}{l}\text { Borehole } \\
\text { designation }\end{array}$ & Location & $\begin{array}{l}\text { Northing } \\
\text { (meters) }\end{array}$ & $\begin{array}{c}\text { Easting } \\
\text { (meters) }\end{array}$ & $\begin{array}{l}\text { Altitude } \\
\text { (meters) }\end{array}$ & $\begin{array}{l}\text { Date } \\
\text { drilling } \\
\text { began }\end{array}$ & $\begin{array}{c}\text { Date } \\
\text { drilling } \\
\text { completed }\end{array}$ & $\begin{array}{c}\text { Total } \\
\text { depth } \\
\text { (meters) }\end{array}$ \\
\hline UE-25 UZ\#16 & WT-2 Wash & 231811 & 172169 & 1220 & $5 / 27 / 92$ & $3 / 11 / 93$ & 514.0 \\
\hline USW UZ-14 & Drill Hole Wash & 235155 & 170774 & 1350 & $4 / 15 / 93$ & $5 / 13 / 94$ & 672.6 \\
\hline USW UZ-7a & WT-2 Wash & 231845 & 171397 & 1290 & $3 / 22 / 95$ & $6 / 12 / 95$ & 234.7 \\
\hline USW SD-7 & Highway Ridge & 231328 & 171066 & 1363 & $10 / 3 / 94$ & $11 / 9 / 95$ & 497.5 \\
\hline USW SD-9 & Wren Wash & 234083 & 171242 & 1302 & $5 / 6 / 94$ & $9 / 26 / 94$ & 677.6 \\
\hline USW SD-12 & H-5 Wash & 232244 & 171178 & 1321 & $1 / 28 / 94$ & $8 / 16 / 95$ & 609.6 \\
\hline USW NRG-6 & Drill Hole Wash & 233758 & 172008 & 1248 & $12 / 23 / 92$ & $3 / 4 / 93$ & 335.3 \\
\hline USW NRG-7/7A & Drill Hole Wash & 234355 & 171598 & 1282 & $10 / 25 / 93$ & $3 / 4 / 94$ & 461.3 \\
\hline USW UZ-N11 & Mile High Mesa & 237919 & 170390 & 1592 & $2 / 5 / 92$ & $2 / 25 / 92$ & 25.7 \\
\hline USW UZ-N15 & Bleach Bone Ridge & 237162 & 170643 & 1557 & $3 / 20 / 92$ & $3 / 25 / 92$ & 18.3 \\
\hline USW UZ-N16 & Bleach Bone Ridge & 237180 & 170574 & 1560 & $3 / 25 / 92$ & $3 / 30 / 92$ & 18.3 \\
\hline USW UZ-N17 & Bleach Bone Ridge & 237203 & 170687 & 1563 & $3 / 17 / 92$ & $3 / 19 / 92$ & 18.3 \\
\hline USW UZ-N27 & Yucca Crest & 235174 & 170344 & 1481 & $4 / 21 / 92$ & $4 / 30 / 92$ & 61.7 \\
\hline USW UZ-N31 & Split Wash & 232942 & 171527 & 1266 & $9 / 3 / 92$ & $9 / 22 / 92$ & 58.7 \\
\hline USW UZ-N32 & Split Wash & 232959 & 171541 & 1267 & $9 / 23 / 92$ & $10 / 9 / 92$ & 63.2 \\
\hline USW UZ-N33 & Drill Hole Wash & 234717 & 171051 & 1320 & $8 / 13 / 92$ & $8 / 18 / 92$ & 22.9 \\
\hline USW UZ-N34 & Drill Hole Wash & 234744 & 171069 & 1318 & $8 / 18 / 92$ & $8 / 24 / 92$ & 25.6 \\
\hline USW UZ-N35 & H-5 Wash & 232338 & 171392 & 1295 & 10/13/92 & $10 / 26 / 92$ & 52.0 \\
\hline USW UZ-N36 & Bleach Bone Ridge & 235885 & 171780 & 1415 & $2 / 28 / 92$ & $3 / 2 / 92$ & 18.2 \\
\hline USW UZ-N37 & Wren Wash & 233934 & 171820 & 1257 & $1 / 6 / 92$ & $1 / 30 / 92$ & 82.7 \\
\hline USW UZ-N38 & Wren Wash & 233924 & 171707 & 1265 & $4 / 8 / 92$ & $4 / 13 / 92$ & 27.2 \\
\hline USW UZ-N53 & WT-2 Wash & 231677 & 171979 & 1236 & $5 / 19 / 92$ & $6 / 12 / 92$ & 71.5 \\
\hline USW UZ-N54 & WT-2 Wash & 231731 & 171987 & 1233 & $11 / 12 / 92$ & $12 / 10 / 92$ & 74.6 \\
\hline USW UZ-N55 & WT-2 Wash & 231801 & 171983 & 1241 & $9 / 23 / 91$ & $11 / 8 / 91$ & 77.8 \\
\hline USW UZ-N57 & Abandoned Wash & 230174 & 170941 & 1276 & $10 / 28 / 92$ & $11 / 4 / 92$ & 36.2 \\
\hline USW UZ-N58 & Abandoned Wash & 230197 & 170951 & 1274 & $11 / 5 / 92$ & $11 / 10 / 92$ & 36.2 \\
\hline USW UZ-N59 & Abandoned Wash & 230222 & 170959 & 1274 & $11 / 18 / 92$ & $12 / 8 / 92$ & 36.2 \\
\hline USW UZ-N61 & Abandoned Wash & 230239 & 170960 & 1275 & $12 / 9 / 92$ & $12 / 17 / 92$ & 36.2 \\
\hline USW UZ-N62 & Yucca Crest & 230772 & 170171 & 1489 & $3 / 5 / 93$ & $3 / 10 / 93$ & 18.3 \\
\hline UE-25 UZN \#63 & Pagany Wash & 234341 & 172568 & 1202 & $8 / 3 / 92$ & $8 / 10 / 92$ & 18.3 \\
\hline USW UZ-N64 & Yucca Crest & 233394 & 170516 & 1460 & $4 / 16 / 92$ & $4 / 17 / 92$ & 18.3 \\
\hline
\end{tabular}


Table 4. Generalized lithostratigraphy of eight deep boreholes.

[Breaks in vertical lines indicate unit not present or not collected in the borehole]

Boreholes

Lithostratigraphic unit

SD7 UZ16 SD12 UZ7a SD9 NRG7A NRG6 UZ14

Tiva Canyon Tuff (Tpc)

middle nontithophysal zone (pmn)

lower lithophysal zone (pil)

lower nonlithophysal zone ( $\mathrm{pln}$ )

hackly subzone (plnh)

columnar subzone (plnc)

vitric zone (pv)

moderately welded subzone ( $\mathrm{pv} 2)$

non- to partially welded subzone (pv1)

Pre-Tiva Canyon Tuff bedded tuff(Tpbt4)

Yucea Mountain Tuff (Tpy)

Pre-Yucca Mountain Tuff bedded tuff (Tpbt3)

Pah Canyon Tuff (Tpp)

Pre-Pah Canyon Tuff bedded tuff(Tpbt2)

Topopah Spring Tuff (Tpt)

crystal-rich member (Tptr)

vitric zone (rv)

nonwelded subzone (rv3)

moderately welded subzone (rv2)

densely welded subzone (rv1)

nonlithophysal zone (rn)

dense subzone (m3)

vapor-phase corroded subzone ( $\mathrm{rn} 2)$

lithophysal zone (rl)

crystal-poor member (Tptp)

upper lithophysal zone (pul)

middle nonlithophysal zone (pmn)

lower lithohysal zone (pll)

lower nonlithophysal zone ( $\mathrm{pln}$ )

vitric zone (pv)

densely welded subzone (pv3)

moderately welded subzone (pv2)

nonwelded subzone ( $\mathrm{pv} 1$ )

Pre-Topopah Spring Tuff bedded tuff (Tpbt 1)

CALICO HILLS FORMATION (Tac)

Unit 4 vitric/zeolitic

Unit 3 zeolitic

Unit 2 zeolitic

Unit 1 zeolitic

Bedded tuff (Tacbt)

Basal sandstone (Tacbs)

Prow PassTuff (Tcp)

Unit 4 Pyroxene rich

Unit 3 Welded pyroclastic flow

Unit 2 Lithic-rich pyroclastic flow

Unit 1 Pumicesus pyroclastic flow

Pre-Prow Pass bedded tuff(Tcpbt)

Bullfrog Tuff (Tcb)

Tram Tuff (Tct) 
Table 5. Generalized lithostratigraphy of 23 neutron boreholes.

[Breaks in vertical lines indicate unit is missing or was not collected from borehole; trans., transition; part, partially; Can., Canyon; Mtn., Mountain]

\section{Boreholes}

Lithostratig raphic Unit

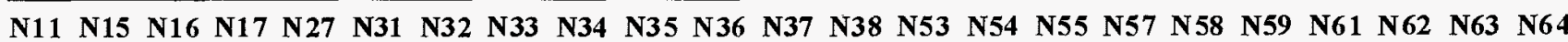

Tiva Canyon Tuff (Tpc)

crystal-rich member (Tpcr)

nonlithophysal zone (m)

subvitrophyre trans. subzone (rn4)

pumice-poor subzone (m3)

mixed pumice subzone (rn2)

crystal transition subzone ( $\mathrm{rn} 1)$

lithophysal zone (rl)

crystal-poor member (Tpcp)

upper lithophysal zone (pul)

middle nonlithophysal zone (pmn)

lower lithophysal zone (pll)

lower nonlithophysal zone (pln)

hackly subzone (plnh)

columnar subzone (plnc)

vitric zone (pv)

moderately welded subzone (pv2)

non- to part. welded subzone (pv1)

Pre-Tiva Can. Tuff bedded tuff (Tpbt4)

Yucca Mountain Tuff (Tpy)

Pre-Yucca Mtn. Tuff bedded tuff (Tpbt3)

Pah Canyon Tuff (Tpp)

Pre-Pah Canyon Tuff bedded tuff (Tpbt2)

Topopah Spring Tuff (Tpt)

crystal-rich member (Tptr)

vitric zone (rv)

nonwelded subzone (rv3)

moderately welded subzone (rv2)

densely welded subzone (rvl)

nonlithophysal zone (rn)

dense subzone ( $\mathrm{rn} 3$ )

vapor-phase corroded subzone (rn2)

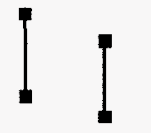

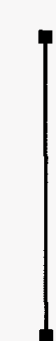

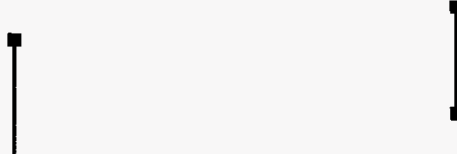

lithophysal zone (rl)
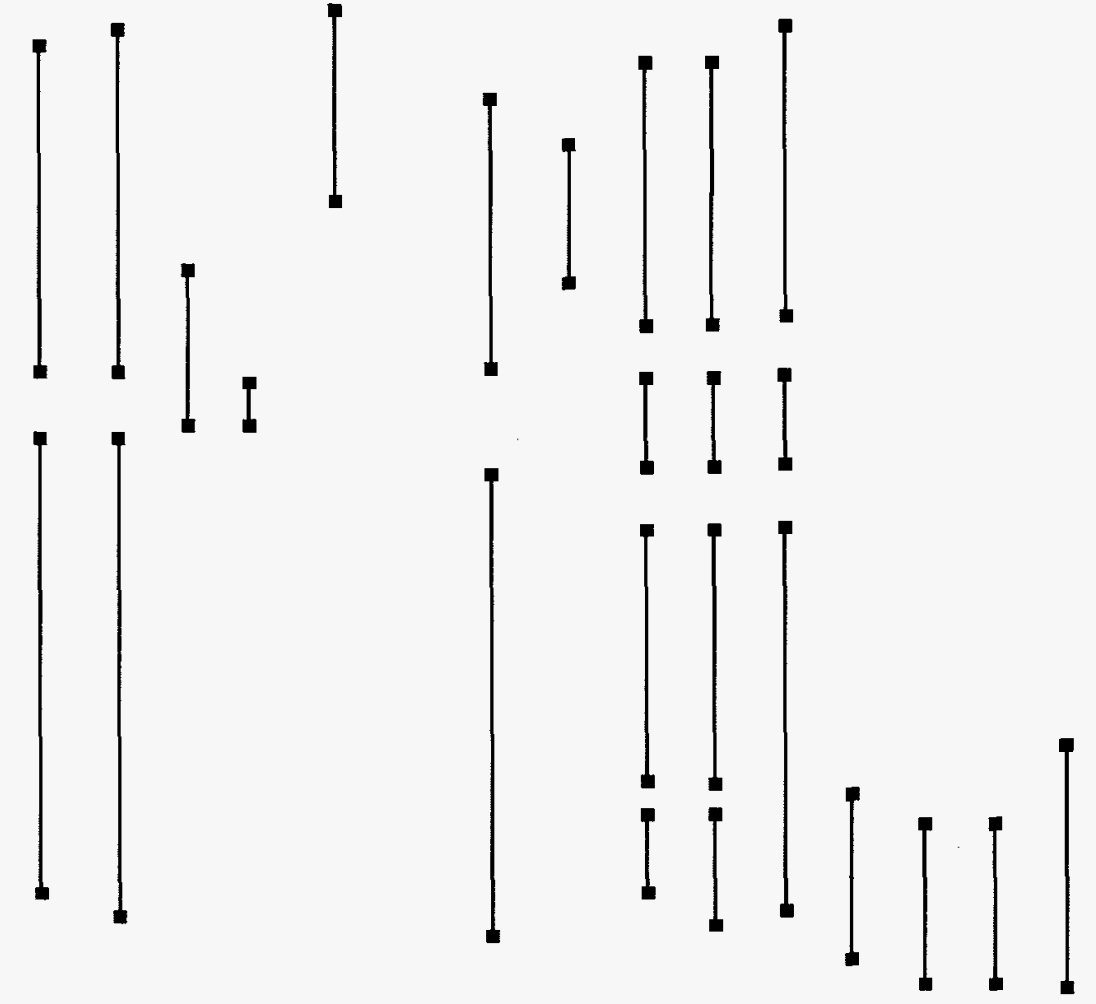
Borehole core, $7 \mathrm{~cm}$ in diameter, is divided into segments:

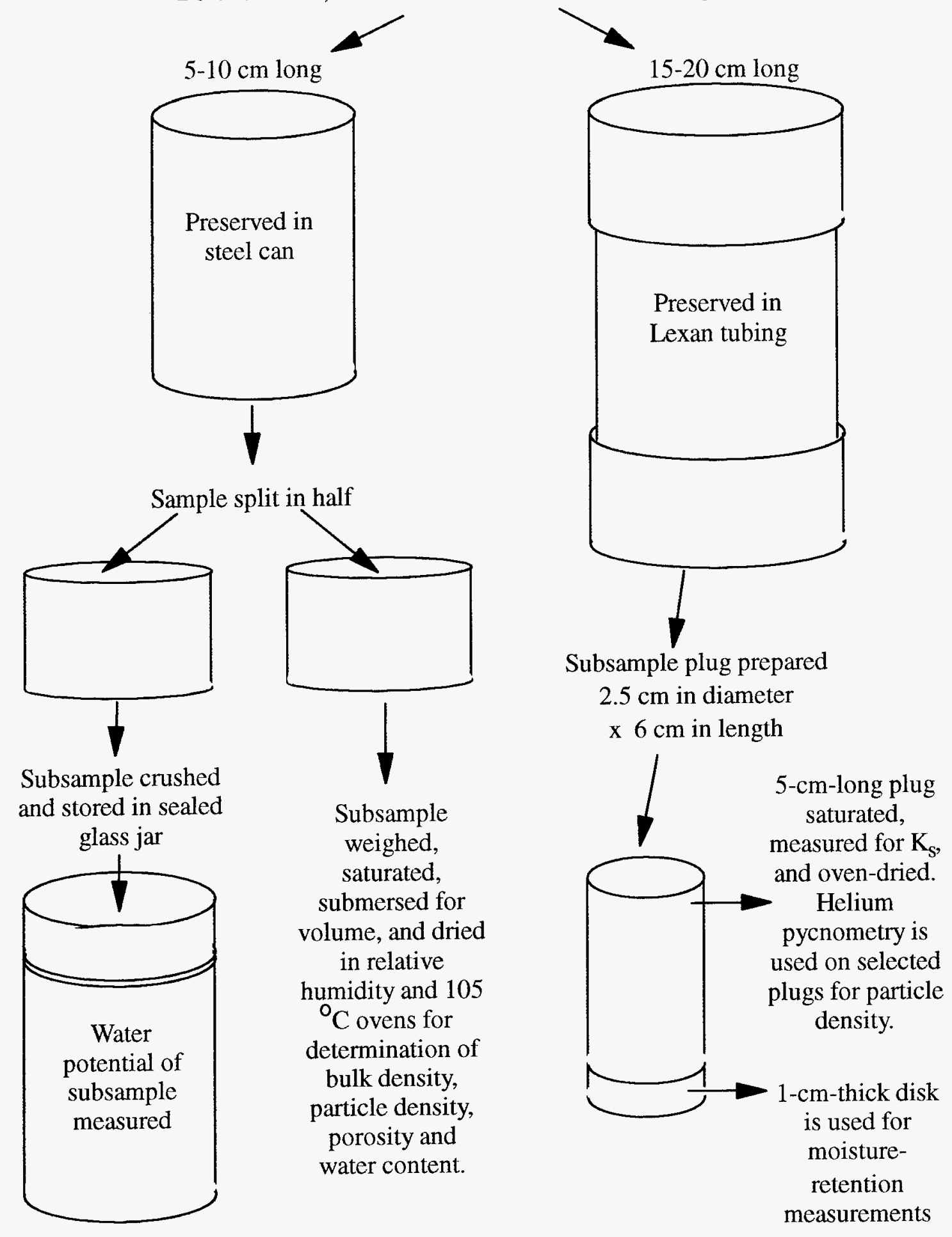

Figure 2. Diagram of the steps used to process core samples to obtain hydrologic property measurements. 
After weighing the first part of the sample for field moisture content, core samples were saturated with $\mathrm{CO}_{2}$ after evacuation of air under a vacuum to enable the saturation of small internal pores and then submersed in distilled, de-aired water and left overnight. Samples were removed, dried with a damp towel (ASTM, 1977), and weighed to determine saturated weight. The sample was suspended in a beaker of water in a wire basket to determine volume displacement, dried for 48 hours in a relative humidity oven at $60^{\circ} \mathrm{C}$ and 65 percent relative humidity $(\mathrm{RH})$, and reweighed. Relative-humidity drying removes water from the pores that contribute to water flow but retains bound water in the crystal or mineral structure (Bush and Jenkins, 1970) or within very small pores or channels, providing an estimate of residual water content and relating pore space to that space available for water flow (see discussion in section on alteration, microfractures, and permeability). The samples were then dried at $105^{\circ} \mathrm{C}$ for at least 48 hours to obtain a standard dry weight (ASTM, 1971). Porosity [(saturated weight minus dry weight)/volume], bulk density (dry weight/ volume), and particle density [porosity/(1 minus bulk density)] were calculated for both $\mathrm{RH}$ and $105^{\circ} \mathrm{C}$ ovendry weights. The error in these measurements is due to resolution of the balances in the weight measurements, which is insignificant, and in the repeatability of the saturated weight and volume measurement based on removing surface water from the rock. Errors have been calculated to be less than 0.5 percent for bulk properties. Volumetric-water content is calculated as [(initial weight minus dry weight)/dry weight] multiplied by bulk density, and saturation is volumetricwater content divided by porosity. The error in these measurements is the same as for the physical properties, but includes a calculation for evaporation during sample handling, which is discussed in a later section.

Borehole core segments, $15-20 \mathrm{~cm}$ long, were collected adjacent to can samples and preserved in Lexan tubing for measurements of saturated hydraulic conductivity, particle density using helium pycnometry, and moisture retention (fig. 2). Subsamples, $2.5 \mathrm{~cm}$ in diameter and approximately $6 \mathrm{~cm}$ long, were prepared and subsamples, approximately $1 \mathrm{~cm}$ long, were cut off the end of these samples for determination of moisture-retention curves. The rest of the subsample was used for conductivity and helium-pycnometry measurements. Hydrologic flow properties were measured before conventional oven drying $\left(105^{\circ} \mathrm{C}\right)$ because structural damage may occur in certain samples with delicate clay structures or zeolites. Finally, the samples were dried at $105^{\circ} \mathrm{C}$ to obtain a standard dry weight.

Saturated hydraulic conductivity $\left(K_{s}\right)$ was determined on subsamples from several boreholes. Cores were vacuum saturated, and $K_{s}$ was measured using a steady-state permeameter that forces water through the core at a measured pressure while weighing the outflow over time. $K_{s}$ was calculated using Darcy's law:

$$
\frac{Q}{A t}=K_{s}\left(\frac{\Delta P}{\Delta z}\right)
$$

where $Q$ is the measured flow per unit time, $t$, in meters per second; $A$ is the cross-sectional area of the sample, in square meters; $\Delta P$ is the pressure gradient measured across the core sample, in meters of head; and $\Delta z$ is the length of the sample, in meters. The error in this measurement is estimated to be less than one-half an order of magnitude of the calculated $K_{s}$. This measurement, differing from the typically saturated hydraulic conductivity that occurs under field conditions when rocks have entrapped air, provides an upper bound to the prediction of unsaturated hydraulic conductivity necessary for the numerical modeling of water flow through rocks.

Helium pycnometry was performed using a helium pycnometer (Accupyc, Model 1330, Micromeritics Corp., Norcross, GA) on 460 samples from borehole UZ16 that had been oven-dried at $105^{\circ} \mathrm{C}$ following $K_{s}$ measurements. The pycnometry technique uses Boyles' gas law to measure the volume of the solids of a dry sample once all void spaces (pores) are filled with helium. The volume of the solids divided by the sample weight is the particle density. The error in this measurement is less than 0.5 percent. This technique provides information about the pore spaces because of the properties of helium. Helium differs from water because it is nonpolar and will not fill all of the spaces voided by water molecules, such as spaces within clay structures (see Characterization of Hydrogeologic Units, Phase 2).

\section{Moisture-Retention Characterization}

At sites where no measured unsaturated hydraulic-conductivity data are available, moisture-retention 
curves are used with saturated hydraulic conductivity to predict unsaturated hydraulic conductivity. Moisture-retention curves were determined in the laboratory by using the chilled-mirror psychrometer to determine water potential at various saturations. Samples were vacuum saturated, and water-potential measurements were made. Following the measurement, samples were allowed to dry by evaporation to a new water content and then equilibrate in a sealed jar for approximately 3 days. Measurement points were collected at each saturation in this manner until the final measurement point was determined following the drying of the sample in an oven set at $60^{\circ} \mathrm{C}$ and 65 percent relative humidity. The final measurement point was used to approximate the residual water content. For each hydrogeologic unit, the data sets for individual samples were compiled to include variability throughout the unit. These data sets represent the desorption process and are the upper bound of the moisture-retention characteristic curve, neglecting hysteretic behavior. For rock units in the shallow unsaturated zone where hysteretic behavior might occur due to periodic wetting and drying and entrapment of air in pores, measured data from borehole samples were included with the laboratory data set to produce a composite data set. This was done for hydrogeologic units of the Tiva Canyon Tuff (with the exception of Tpcrn and Tpcpul, because no field waterpotential measurements were available), the PTn, and the upper rocks of the Topopah Spring Tuff (Tptrv and Tptrn). Data points from the field data that were determined to be saturated were set to -0.01 bars for all calculations and for curve-fitting procedures. Field data used in the composite-curve data sets were also corrected for evaporation losses using the procedure outlined in the following section. Composite data sets were developed by combining laboratory and field data into bins represented by equal ranges of saturation and determining the geometric mean of each bin. This was done so that the curve-fitting procedure and resulting curve-fit models wouldn't be biased or weighted due to oversampling.

Each of the moisture-retention data sets was fitted with curve functions using RETC (van Genuchten and others, 1991), a least-squares curve-fitting procedure based on van Genuchten (1980) and fitting van Genuchten's parameters $\alpha$ and $n$, while $m=1-(1 / n)$. Water potential $(\psi)$ is related to effective saturation $(\mathrm{Se})$ by

$$
\psi=\frac{\left[S e^{\langle-1 / m\rangle-1}\right]^{\langle 1 / n\rangle}}{\alpha}
$$

where effective saturation is

$$
S e=\frac{\left(\theta-\theta_{r}\right)}{\left(\theta_{s}-\theta_{r}\right)}
$$

and $\theta$ is measured water content in meters per meter, $\theta_{r}$ is residual water content in meters per meter, and $\theta_{s}$ is water content at saturation in meters per meter. Residual water content, estimated from the difference between $105^{\circ} \mathrm{C}$ oven-dry weight and RH oven-dry weight, was set and saturated water content was set to 1 . (Residual water content is discussed in more detail in Characterization of Hydrogeologic Units, Phase 2). An error based on the resolution of the instrument was used to calculate an error in water potential over the range of the instrument. The calculated water-potential error was added to each measured laboratory data point, and a new curve was fit to the data and the standard error for the fit parameters was calculated. The error was also subtracted from the measured points and a curve was fit to the new data set. Standard errors and 95-percent confidence limits were also calculated for each of the fit parameters for each moisture-retention curve. Moisture-retention curve-fit parameters were then used to predict water potential from measured saturation using equation 3 and equation 4 in several boreholes for comparison with measured water potential. The water-content and water-potential values were corrected prior to the predictions by using the method described in the next section.

Unsaturated hydraulic conductivity, $K_{\text {rel }}(\psi)$, can be predicted from moisture-retention fit parameters using the model of van Genuchten/Mualem

(van Genuchten, 1980):

$$
K_{r e l}(\psi)=\frac{\left(1-(\alpha \psi)^{n-1}\left[1+(\alpha \psi)^{n}\right]^{-m}\right)^{2}}{\left[1+(\alpha \psi)^{n}\right]^{m / 2}}
$$

with $m=1-(1 / n)$.

\section{Correction of Water-Content and Water- Potential Data}

Drilling and sample handling can variably reduce the saturation and the water potential of core 
samples so that they do not represent true field conditions. To more accurately represent in-situ waterpotential values, an analysis was done to correct the effects of drilling and sample handling on the determination of core water content and water potential. The degree of saturation in a core is not very sensitive to these influences, but water potential can be reduced significantly where small amounts of water are evaporated from samples of certain rock types, such as Tptrv1, Tptpv3, and other low-porosity rocks. The influence of drying on the measurement of water potential is particularly notable at the wet or dry ends of a moisture-retention curve where the relation of water potential to water content is steep; thus, a small loss in water content results in a large decrease in water potential. Loss of water will affect the water potential more for rocks with very small pores than for those with larger pores and higher porosity.

There are three potential situations during which water can be lost from the sample. The first is during the borehole drilling when the core is exposed to drilling air. The second situation is in the trailer at the drill site when the inner barrel encasing the core is opened. The amount of time from when the core barrel is opened to when each sample is sealed in the steel can varies, but typically does not exceed 5 minutes. The last situation is when the can is opened at the laboratory for the processing of core. It takes no longer than 30 seconds to obtain an initial weight on one subsample and crush and seal the other subsample in a glass jar (fig. 2).

The analysis was done in several steps. First, an evaporation curve was generated for each unit. Samples of 2.5-cm-diameter core plugs representing all of the hydrogeologic units at Yucca Mountain were vacuum saturated and water in each sample was allowed to evaporate under ambient laboratory conditions on a top-loading balance from which weight readings were recorded every 10 seconds by a computer. These data were used to generate evaporation curves of water loss (in grams of water) over time for all rock types. Water loss was calculated as the percentage of the total volume of water within the pores that evaporated over time. This calculation could be used to correct water loss from borehole samples of various sizes and initial water content. Using drilling data from borehole SD9, which recorded the rate of penetration with depth, the amount of time that each rock type was exposed to drilling air was calculated. It was assumed that samples were exposed in the trailer at the drill site during packaging for an average of 5 minutes and that it took 30 seconds to process each sample in the laboratory to obtain initial water content. To correct each sample for error due to evaporation, it was assumed that evaporation was a function of sample size (related to surface area and measured as total dry weight) and initial volume of water in the sample. The total volume of water initially in each sample was calculated, and the appropriate percentage of water evaporated was taken from the evaporation curve for the time that the sample depth was exposed to drilling air and sample handling. This was done for each sample to determine the amount of water to be added to the initial weight in order to correct the error in saturation. The moisture-retention function for each hydrogeologic unit was then used to calculate the water potential from the initial saturation and the corrected saturation, and the difference between these values was added to the measured water potential. Corrected saturation and water-potential values were only used in this report to produce the composite moisture-retention curves discussed above and to compare with the predicted water-potential values. Corrected saturation and water-potential values, though only presented in this report for SD7 and SD9, are also available for SD12, UZ14, and UZ7a (table 2).

\section{CHARACTERIZATION OF HYDROGEOLOGIC UNITS}

The determination of distinct hydrogeologic units for the purpose of numerical flow modeling required a large, spatially distributed data set of hydrologic properties and corresponding lithostratigraphic descriptions. The intent of developing hydrogeologic units as discrete layers with associated parameters and properties for flow models was twofold: (1) that the layers could be related spatially to existing threedimensional lithostratigraphic or porosity models; and (2) that they would be distinct enough, with minimal vertical and lateral heterogeneity, that, when used in a numerical model, they would reasonably predict measured field conditions in a vertical borehole at any location on the mountain, while not being so detailed as to be numerically cumbersome or limiting. With these criteria in mind, the following procedure was implemented: 
Phase 1: Preliminary layer boundaries were chosen based on lithostratigraphic boundaries and porosity profiles. Layers were refined in the transition zones at the top and bottom of the PTn to minimize the range in porosity.

Phase 2: Layer properties were evaluated based on the relationship of $K_{s}$ to porosity, and unique zones were refined where altered materials influence flow, such as at the base of the Tiva Canyon Tuff and in the zeolitized rocks below the Topopah Spring Tuff.

Phase 3: Moisture-retention characteristics of layers were evaluated. Moisture-retention curves are measured on fewer samples than any other measurement and need to represent a spectrum of field measurements. Field measurements were incorporated into laboratory measurements to help represent hysteretic conditions in the shallow layers of the Tiva Canyon Tuff and the PTn. Predicted water potentials were compared with measured water-potential profiles in selected boreholes. If there were moisture-retention characteristics that differed appreciably within layers, then adjustments of layers were made accordingly.

Phase 4: Means and standard deviations were calculated for all properties for each hydrogeologic unit. Arithmetic mean calculations are used for normally distributed properties such as porosity, bulk density, particle density, and water content. Geometric means are used for saturated hydraulic conductivity and water potential. $K_{s}$ is averaged using a geometric mean

$$
K_{s g}=\exp \left[\frac{1}{N} \sum_{i=1}^{N} \log \left(K_{i}\right)\right]
$$

and a power-law average

$$
K_{s w}=\left[\frac{1}{N} \sum_{i=1}^{N} K_{i}^{w}\right]^{\frac{1}{w}}
$$

where $N$ is the number of samples and $w$ is an empirical coefficient. Arithmetic means used to describe the distribution of $K_{s}$ of hydrogeologic units are inappropriate, except for flow parallel to layering in a layered system (McKenna and Rautman, 1996). A vertical distribution of $K_{s}$ in a vertically heterogeneous system is best described by the geometric mean. The major problem with using the geometric mean as an estimate of the effective $K_{s}$ for any given hydrogeologic unit is that the calculated value of the geometric mean can be dominated by a small number of low-value outliers in the data, whereas the actual effective $K_{s}$ may be virtually independent of the low-valued outliers, especially in three-dimensional domains (Jensen, 1991). The flow process is primarily driven by the highconductivity values.

The calculation for the power-law average is essentially the same as the geometric mean if $w=0$ (McKenna and Rautman, 1996). If the property distribution is described by an arithmetic mean, then $w=1$. A distribution described by a harmonic mean uses $w=-1$. This is best used when flow is perpendicular to the stratification within the system. This calculation is used extensively in the oil industry to estimate the effective hydraulic conductivity of simulated grid blocks from core-scale measurements (Journel and others, 1986; Deutsch, 1989). A series of numerical experiments simulating flow through a cross-sectional model of Yucca Mountain indicates a power coefficient of -0.4 is appropriate for the tuffs at this site due to the dips of the units (McKenna and Rautman, 1996), and this value was used for the calculations in this report.

If significant variances existed within hydrogeologic units that could be reduced by the adjustment of layer boundaries, then the appropriate adjustments were made, particularly where porosity was the factor determining the location of the boundary. A final consideration was that of the spatial distribution of the mean porosity for those hydrogeologic units penetrated by a large number of boreholes. It was considered useful to assess horizontal trends or outliers for incorporation into the layer development.

As outlined above, division of the rocks into hydrogeologic units is an iterative process. Hydrogeologic unit divisions were initially made based on lithostratigraphic unit boundaries, refined based on changes in porosity and other properties such as moisture-retention characteristics, evaluated as to statistical similarity, and examined in the context of lithostratigraphic features. This section describes the nomenclature and character of the hydrogeologic units and is followed by details and rationale behind the influences of the various features, alteration and permeability, and moistureretention character. Hydrogeologic-unit nomenclature is associated with lithostratigraphic units in table 1. Nomenclature abbreviations are maintained at a maximum of three letters for the ease of creating numerical 
model input files and generally are related to nomenclature abbreviations from Scott and Bonk (1984).

Porosity, saturation, and particle density are generally good indicators of lithostratigraphic boundaries (table 1) and are shown, along with lithostratigraphic units, for samples from two deep boreholes, SD7 and SD9 (figs. 3 and 4). These figures exemplify the vertically stratified nature of the unsaturated zone at Yucca Mountain. The shading represents the formations Tpc, Tpt, and Tcp (table 1). Corrected saturation and water potential are shown for each borehole with a line indicating water potential calculated for no-flow conditions in equilibrium with the water table. Many of the waterpotential measurements lie to the right of this calculated no-flow line, which suggests (though highly unlikely) that there is a mechanism contributing to the drying out of the formation at great depths. Most likely, the values outside the no-flow line are located in rocks that are subject to drilling or sample-handling effects that were not or could not be accounted for in the error analysis and corrections. In general, porosity is high and saturation is low in the nonwelded rocks, except for those close to the water table, and porosity is low and saturation is high in the welded rocks (table 1; figs. 3, 4). Particle density is generally high in the devitrified rocks and low in the vitric rocks (table 1). The details of the individual units are discussed below.

\section{Phase 1: Porosity Profiles}

A useful first step in developing layers for hydrologic flow models uses lithology and its corresponding relationship with porosity. Porosity has been shown to be a reasonable surrogate for flow properties when relationships are developed according to the lithologic and alteration character of the rocks (Flint and others, 1996b; Istok and others, 1994; Schenker and others, 1994). Keeping in mind that all layer divisions have to reflect the vertical distribution of rock units (that is, units with similar properties, if separated in space vertically, need to be separate layers), the first separation is by lithostratigraphic unit. In zones where vaporphase corrosion is prevalent, such as in Tpcrn, Tpcplnc, and Tptrn, porosity is used as the determinant for layer boundaries.

\section{Tiva Canyon Tuff}

The Tiva Canyon welded hydrogeologic unit (Tpc) is described by Montazer and Wilson (1984) as the densely to moderately welded uppermost stratigraphic layer that underlies much of Yucca Mountain. It dips $5^{\circ}$ to $10^{\circ}$ eastward, is absent in some washes, and is about $150 \mathrm{~m}$ thick beneath Yucca Crest.

The transition through the uppermost rocks of the Tiva Canyon Tuff is shown in boreholes N36 and N27 (fig. 5). The upper part of Tpcrn4 is densely welded, and the lower part of Tpcrn4 and the underlying Tpcrn 3 are increasingly vapor-phase corroded (table 1). Tpcrn2 and Tpcrn1 have lower porosity and less vapor-phase corrosion than the overlying units, but higher porosity and vapor-phase corrosion than Tpcpul. Boundaries of the hydrogeologic units are selected on the basis of porosity. The boundary between $\boldsymbol{C} \boldsymbol{C R}$ and $\boldsymbol{C U} \boldsymbol{C}$ is located at the depth that the porosity increases to greater than 9 percent, and the boundary between CUC and $\boldsymbol{C U L}$ is located at the depth at which the porosity decreases to less than 20 percent. The CUL has somewhat higher porosity than the underlying densely welded rocks of the Tiva Canyon Tuff, and the lower boundary of CUL is at the lithostratigraphic contact.

The middle and lower parts in the crystallized rocks of the Tiva Canyon Tuff include the Tpcpmn, Tpcpll, and Tpcpln (table 1). As shown in boreholes SD7, N54, N55, and N31, these lithostratigraphic units have low variability in porosity, and, together, comprise $\boldsymbol{C W}$ (figs. 6 and 7). The base of the lower nonlithophysal columnar subzone (Tpcplnc) is higher in porosity due to an increased amount of vapor-phase corrosion, as well as being the initial part of the transition from welded to nonwelded in the vitric rocks below (Buesch and others, 1996b) (figs. 6 and 7). The base of the $\mathrm{CW}$ is where the porosity increases in the vapor-phase corroded rocks to 15 percent or greater.

\section{Nonwelded Paintbrush Tuff and Base of Tiva Canyon Tuff}

The Paintbrush nonwelded hydrogeologic unit of Montazer and Wilson (1984) is described as consisting of the nonwelded and partially welded base of the Tiva Canyon Tuff, the Yucca Mountain and Pah Canyon Tuffs, the upper nonwelded and partially welded upper part of the Topopah Spring Tuff, and the associated bedded tuffs. It consists of thin, nonwelded ash-flow 

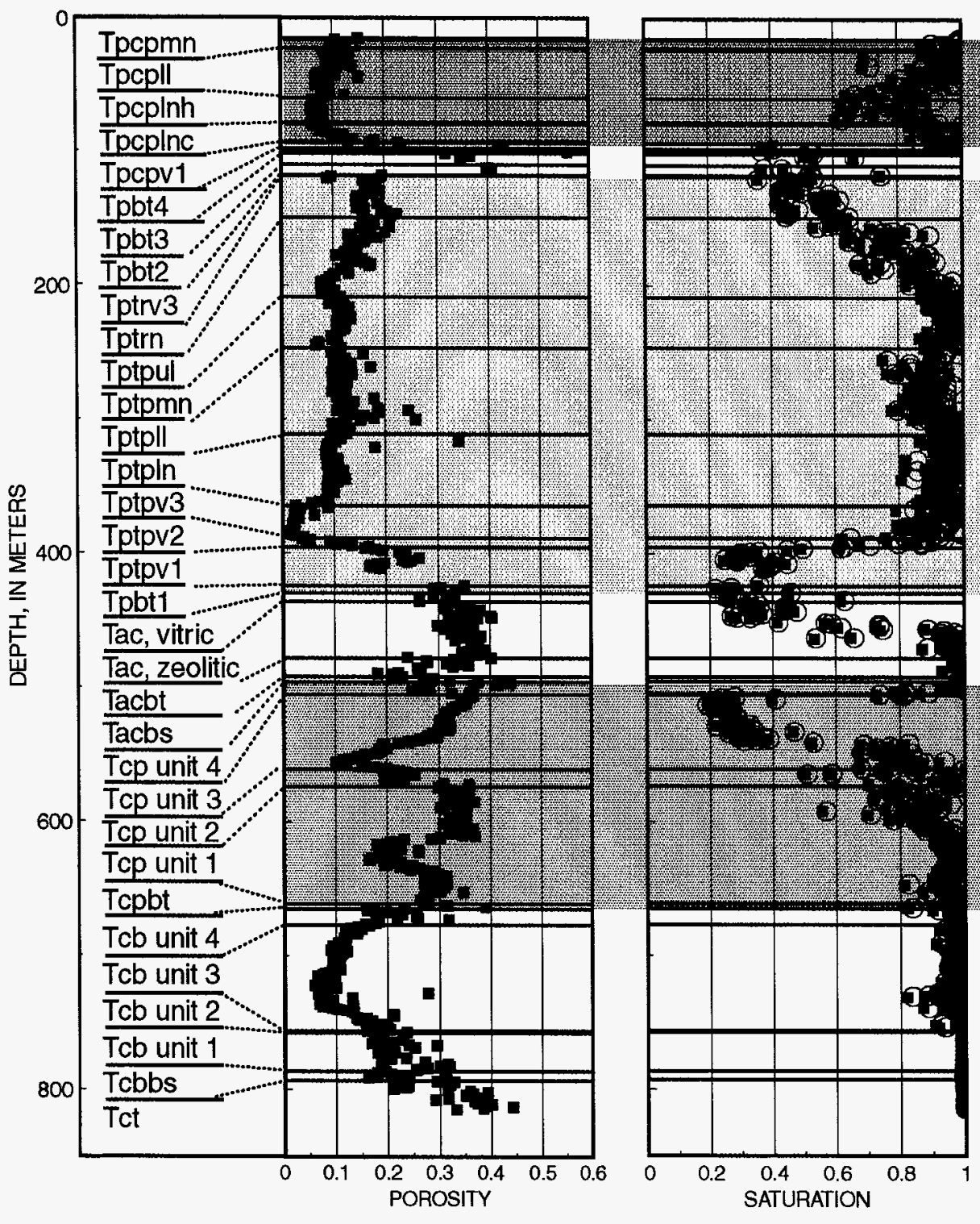
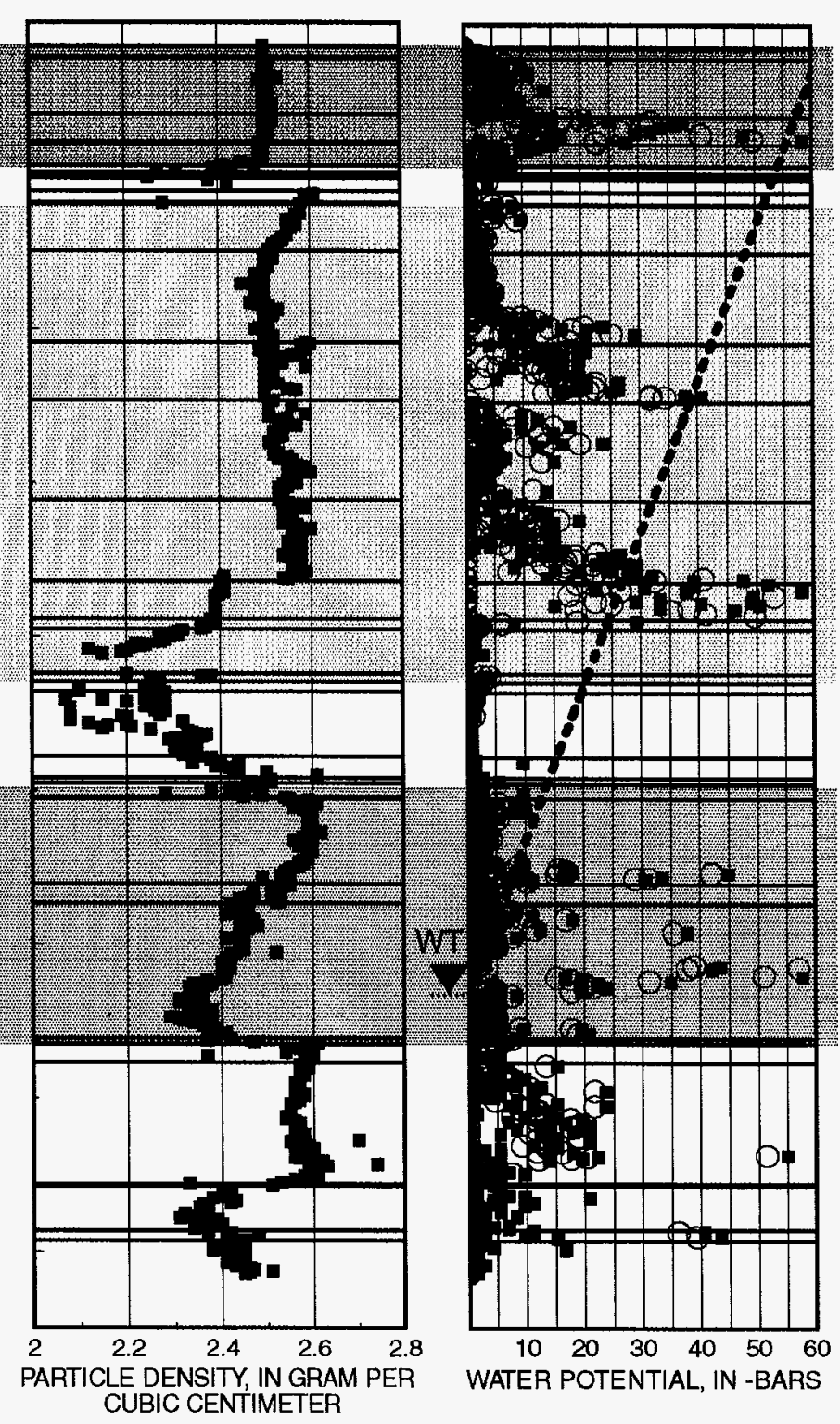

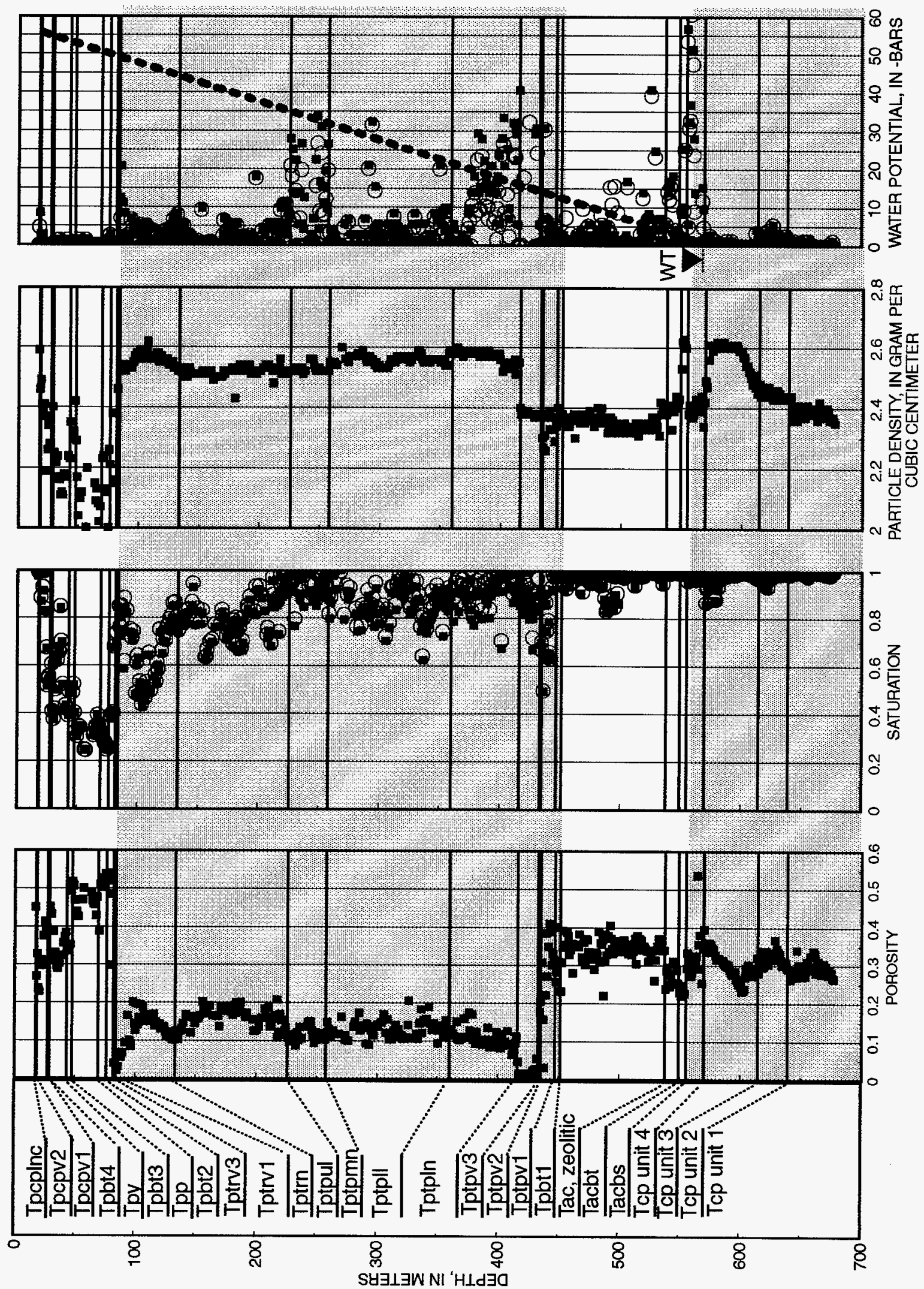

Figure 4. Porosity, saturation, particle density, and water potential with calculated no-flow conditions in equilibrium with the water table, with depth for borehole SD9. 

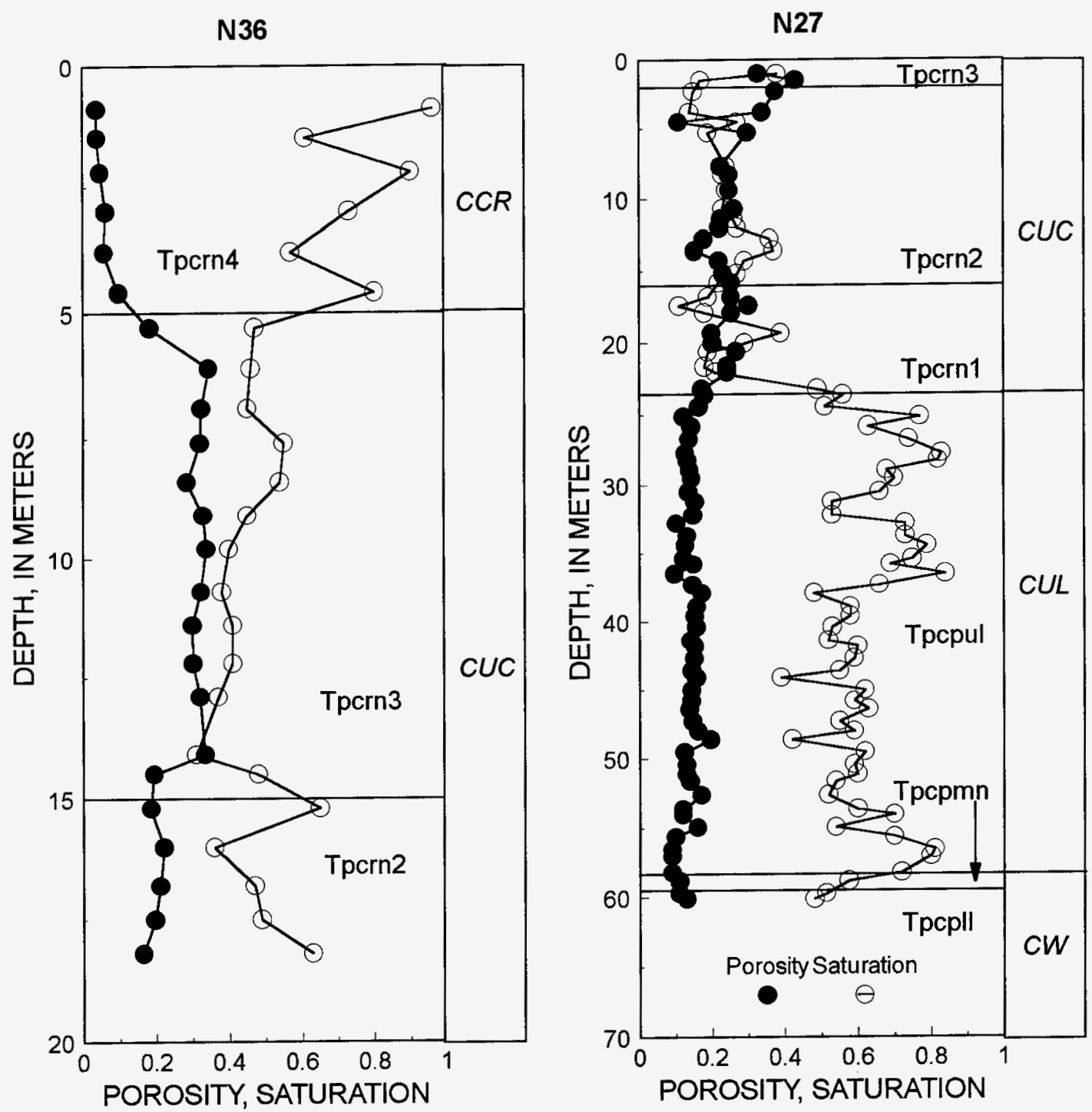

Figure 5. Oven-dry porosity and saturation profiles for rocks from the upper part of the Tiva Canyon Tuff in boreholes N36 and N27. 

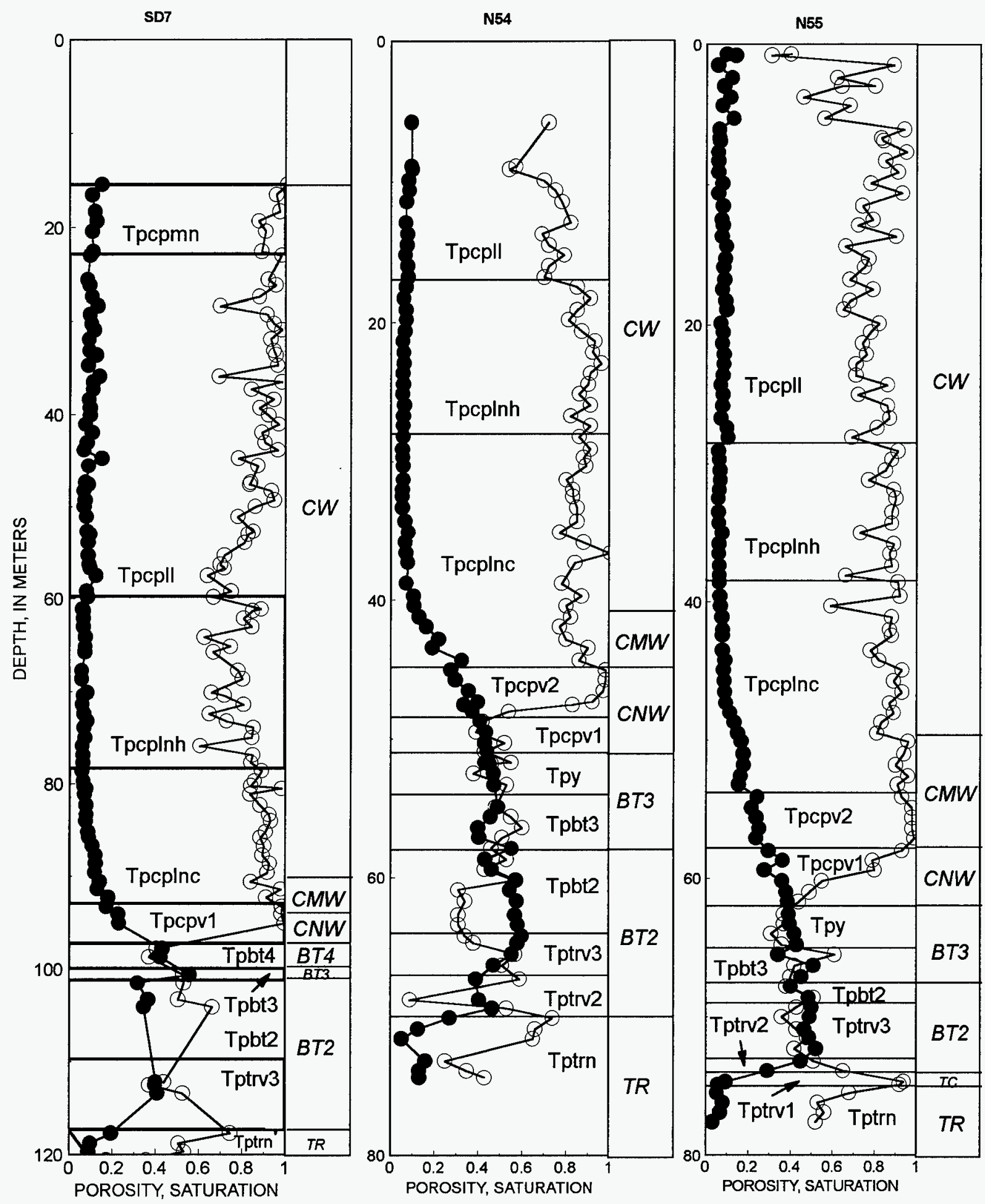

Figure 6. Oven-dry porosity and saturation profiles for rocks between the lower part of the Tiva Canyon Tuff, bedded tuffs of the Paintbrush Group, Yucca Mountain and Pah Canyon Tuffs, and the upper part of the Topopah Spring Tuff for boreholes SD7, N54, and N55. 
N31

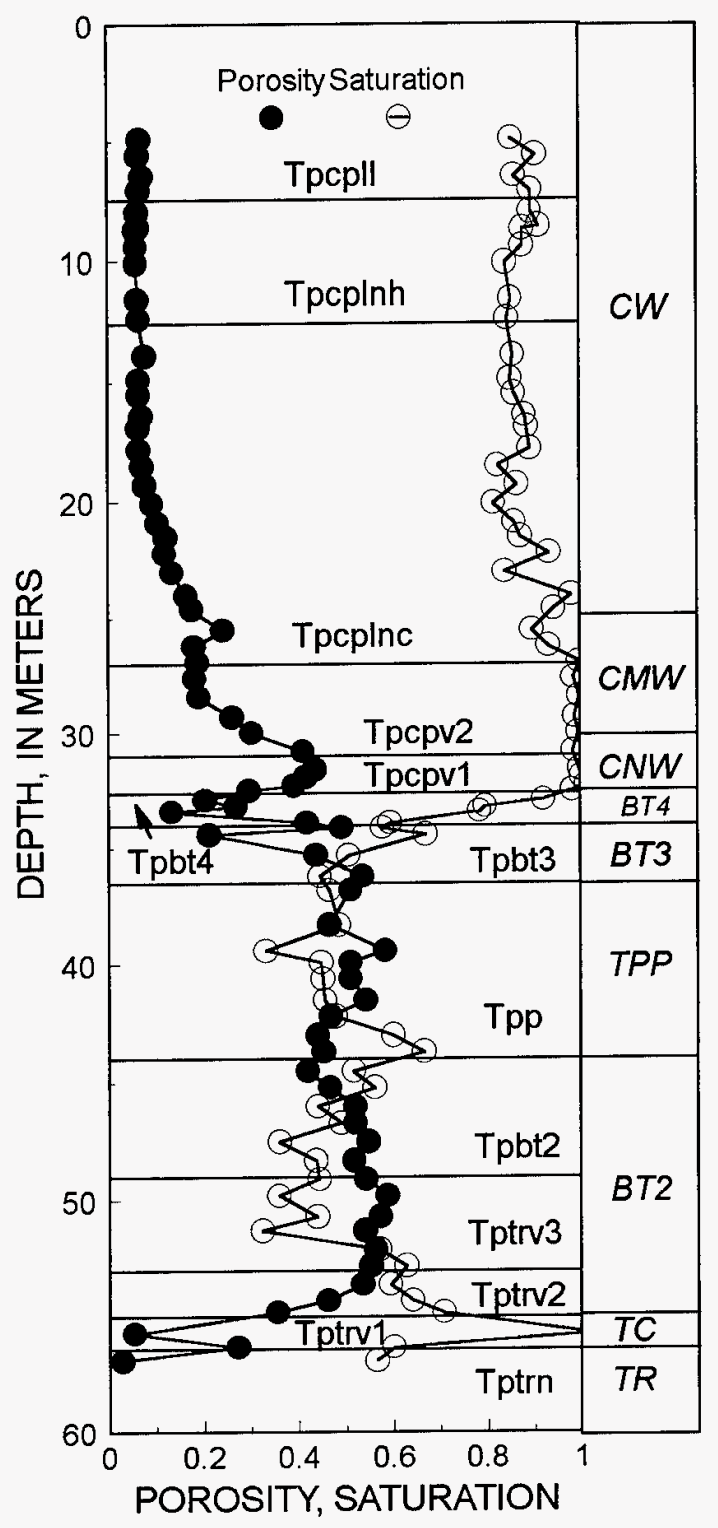

SD9

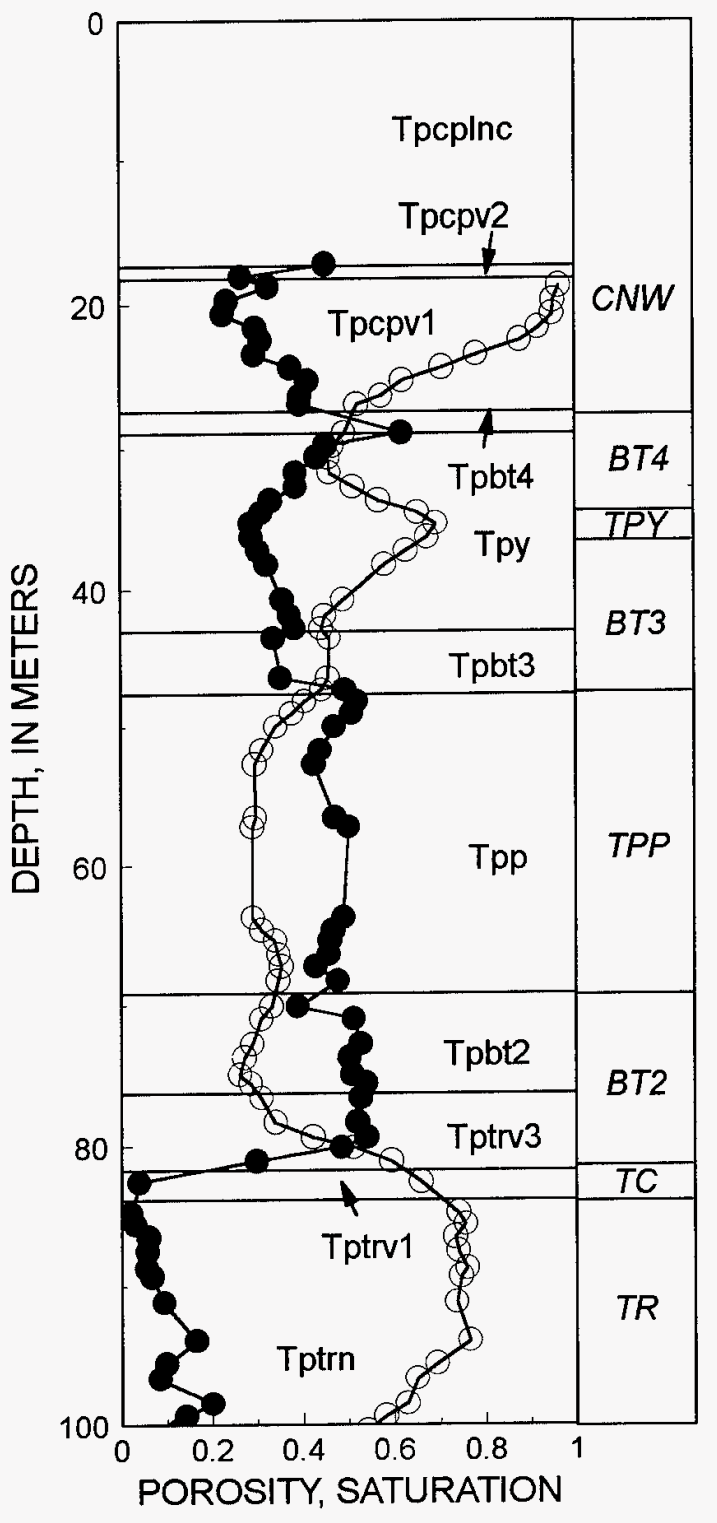

Figure 7. Oven-dry porosity and saturation profiles for rocks from the Paintbrush Group between the lower Tiva Canyon Tuff and upper Topopah Spring Tuff in boreholes N31 and SD9. 
sheets and bedded tuffs that thin to the southeast from a maximum thickness of $100 \mathrm{~m}$ to a minimum of about $20 \mathrm{~m}$. This unit crops out in several locations, particularly along Solitario Canyon and Yucca Wash.

To define the detailed character of these rocks for this study, they are separated into several hydrogeologic units. The rocks near the base of the Tiva Canyon Tuff are characterized by a transition in porosity and also in mineral alteration and are divided into the $C M W$ and $\boldsymbol{C N W}$ hydrogeologic units. The CMW hydrogeologic unit consists of moderately welded rocks near the base of the Tpcplnc and usually most of Tpcpv2 and ranges from greater than 15 percent porosity at the top of the unit to greater than 28 percent porosity at the bottom of the unit (figs. 6 and 7). The CNW consists of nonwelded to partially welded rocks in Tpcpv1 and locally includes the base of Tpcpv2 (figs. 6 and 7).

The lithostratigraphic units of the PTn commonly are thin, but distinct enough in properties to delineate as separate hydrogeologic units. A numerical modeling exercise was done by Flint and others (1996a) to assess the hydrologic impact of these individual units and whether the properties were different enough to maintain the individual layers as separate units. It was determined that abrupt and linear contacts, along with the contrasts in properties, were instrumental in creating lateral diversion along the sloping contacts. As an exercise, this indicated that the property contrasts were different enough in most cases to maintain separate units. However, in reality, this exercise simplified the linear character of the contacts. These contacts are only locally linear and are less likely to divert water laterally due to heterogeneities that cause increases in saturation and local instabilities that result in penetration across the boundary. The Yucca Mountain Tuff (Tpy) has properties very similar to the Tpbt4 and Tpbt3 to the south of Drill Hole Wash (fig. 6 , boreholes N54 and N55), but has lower porosity and becomes moderately welded to the north (fig. 7, see borehole SD9). In the modeling exercise (Flint and others, 1996a; Moyer and others, 1996), this unit was represented by the properties of the lower porosity rocks, and it diverted water laterally. As a result, $\boldsymbol{T P Y}$ represents rocks of less than or equal to 30 percent porosity. In boreholes where the TPY is greater than 30 percent porosity, the properties of BT4 are used to represent the TPY. If no BT4 exists in the borehole, properties from the unit Tpbt3 are used. Typically to the south of Drill Hole Wash, the hydrogeologic unit BT3 represents both Yucca Mountain Tuff and Tpbt3. The
Pah Canyon Tuff is welded far to the north in Yucca Wash, but no boreholes sampled in that unit contained welded or even moderately welded rocks; therefore, the nonwelded to partially welded Pah Canyon Tuff is hydrogeologic unit TPP. The Tpbt 2 and the nonwelded top of the Topopah Spring Tuff, Tptrv3, were not different enough in properties to maintain as separate units (Flint and others, 1996a; Moyer and others, 1996) and are represented by hydrogeologic unit $\boldsymbol{B} \boldsymbol{T} 2$.

Tptrv2 is a thin unit that transitions sharply from nonwelded to densely welded rock such that the sample spacing of $0.8 \mathrm{~m}$ was not enough to characterize the transition, and it is included as the lower part of BT2.

\section{Topopah Spring Tuff}

The Topopah Spring welded unit (Montazer and Wilson, 1984) consists of a very thin upper vitrophyre; a thick central zone consisting of several densely welded, devitrified ash-flow sheets; and a thin lower vitrophyre. The unit contains several lithophysal cavity zones of varying thickness, and the rocks are intensely fractured. This unit is the thickest and most extensive of the Paintbrush Group and contains the central and lower densely welded and devitrified zones being considered for the potential repository.

The vitric, densely welded (Tptrv1) subzone, which contains the vitrophyre, is typically less than $0.5 \mathrm{~m}$ thick, but varies from 0 to $2 \mathrm{~m}$ thick across Yucca Mountain (D.C. Buesch and R.W. Spengler, U.S. Geological Survey, written commun., 1996) (fig. 8). The Tptrv1 typically has porosity less than 5 percent. It has highly contrasting properties to the rocks overlying it. The underlying dense subzone of the crystal-rich nonlithophysal zone (Tptrn3) also has very low porosity (less than 9 percent) and can be combined with the Tptrv1 as the hydrogeologic unit $\boldsymbol{T C}$. Tptrn3 is typically thicker to the north and very thin in the southern parts of the study area.

Most of the crystallized, moderately to densely welded Topopah Spring Tuff is divided into five hydrogeologic units that closely correspond to lithostratigraphic units. The vapor-phase corroded and crystaltransition subzones of the crystal-rich nonlithophysal zone (Tptrn2) (fig. 8) have porosity similar to the underlying lithophysal zone, but moisture-retention characteristics differ (discussed below). Therefore, Tptrn 2 is represented by $\boldsymbol{T} \boldsymbol{R}$ and has greater than 9 percent porosity. The lithophysal (Tptrl, Tptpul, and Tptpll) and nonlithophysal (Tptpmn, Tptpln) zones differ 

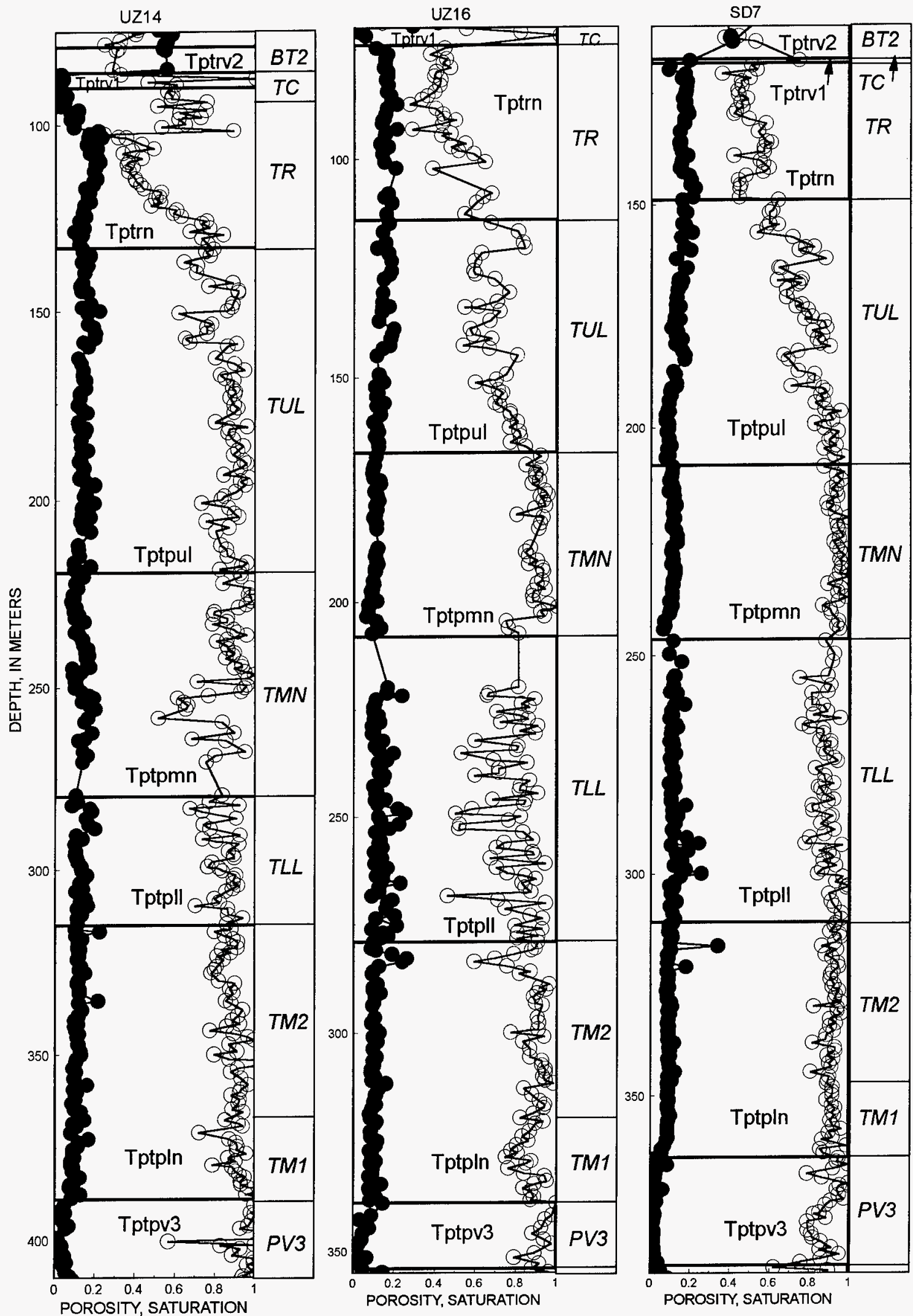

Figure 8. Oven-dry porosity and saturation profiles of rocks from the Topopah Spring Tuff in boreholes UZ14, UZ16, and SD7. 
in porosity with the lithophysal zones being approximately 14 percent porosity and the nonlithophysal zones approximately 11 percent (figs. 3, 4, and 8). They differ particularly in moisture-retention characteristics; therefore, each zone is represented by individual hydrogeologic units: $\boldsymbol{T U} \boldsymbol{L}$, the upper lithophysal zone; $T M N$, the middle nonlithophysal zone; $T L L$, the lower lithophysal zone; and $T M 2$ and $T M 1$, comprising the lower nonlithophysal zone. The lower nonlithophysal zone of the Topopah Spring Tuff transitions into lower porosity (approximately 9 percent) and locally vitric rocks at the base that have different moisture-retention characteristics due to a downward increase in the amount of smectite (Bish and Chipera, 1989) and is, therefore, divided into two hydrogeologic units (discussed below).

Vitric rocks at the base of the Topopah Spring Tuff are highly contrasting in porosity (fig. 9) with rocks above and below them. The very low-porosity densely welded subzone (Tptpv3), which contains the vitrophyre, is a discrete hydrogeologic unit, PV3. The moderately welded subzone (Tptpv2) is $P V 2$. The nonwelded base of the Topopah Spring Tuff, Tptpv1, is similar in properties to the underlying bedded tuff, Tpbtl, and they are combined in hydrogeologic unit BT1.

\section{Calico Hills Formation}

The Calico Hills nonwelded hydrogeologic unit of Montazer and Wilson (1984) includes the nonwelded to partially welded vitric zone, which is locally zeolitic, that is the lowermost part of the Topopah Spring Tuff. It also includes the pre-Topopah Spring Tuff bedded tuff; the beds of the Calico Hills Formation; a bedded tuff; a bedded sandstone; the Prow Pass Tuff, which is nonwelded to welded; the pre-Prow Pass bedded tuff; and the upper part of the Bullfrog Tuff, where it is above the water table. The Prow Pass Tuff and the Bullfrog Tuff are actually within the Crater Flat Group. Within the unsaturated zone, the thickness of this hydrogeologic unit ranges from 0 to more than $500 \mathrm{~m}$.

The Calico Hills Formation examined as part of this study consists of nonwelded pyroclastic flow and thin fallout deposits, and locally there is a basal bedded sandstone. These rocks are either vitric or zeolitic, and this difference strongly controls the flow of water through the rocks. The part of the formation that is pri- marily pyroclastic flow deposits, which includes units 1 to 4 , is divided into hydrogeologic units $\boldsymbol{C H} \boldsymbol{V}$ and $\boldsymbol{C H Z}$, depending on whether or not it is vitric or zeolitic, respectively. The vitric-zeolitic boundary, rather than using lithologic descriptions which typically include estimates of mineral percentages, is based on the degree of hydrologic response. It is defined in this case as a 5-percent difference in the porosities measured using elevated relative humidity (RH) drying and standard $105^{\circ} \mathrm{C}$ oven drying at ambient relative humidity (generally less than 20 percent) (see section in Phase 2 below for more detailed discussion of alteration influences on properties). This value was chosen on the basis of associated abrupt changes in saturation (see SD7, figs. 9 and 10). The bedded tuff near the base of the Calico Hills Formation (Tacbt) is relatively high in porosity, but is partially silicified and contains opal, and this strongly affects the moisture-retention characteristics and permeability. Tacbt, along with the thin basal sandstone, Tacbs, which is similar in properties to the bedded tuff, comprise the hydrogeologic unit, $\boldsymbol{B T}$.

\section{Prow Pass and Bullfrog Tuffs}

The Prow Pass Tuff is only sampled in four deep boreholes used in this study (table 4) and is variable among these boreholes. It is composed of four pyroclastic units and an underlying interval of bedded tuff (fig. 9). Lithostratigraphic units Tcp4, Tcp2, and Tcp1 are sequences of nonwelded to partially welded pyroclastic flow deposits, and Tcp3 is a partially to moderately welded pyroclastic flow deposit that displays a compound cooling history. The alteration of the initially vitric rocks to zeolites is pervasive throughout the Prow Pass Tuff, with the exception of Tcp 3 that is devitrified and vapor-phase crystallized where the welding increases. As a result, the Prow Pass Tuff is hydrogeologically divided based primarily on lithostratigraphic unit boundaries and secondarily on the differential porosity based on the separation of $\mathrm{RH}$ and $105^{\circ} \mathrm{C}$ calculations. In this case, the mechanism is not always as clear and remains basically empirical with the 5-percent differential in porosity relating well to saturation profiles and moisture-retention characteristics. The hydrogeologic units are PP4, which is equivalent to lithostratigraphic unit Tcp4 and is altered to zeolites and high in porosity; PP3, which is the upper part of Tcp3, is high in porosity, and has no zeolites, but is high in vapor-phase minerals that appear to influence the 5-percent differential porosity; PP2, which is the 

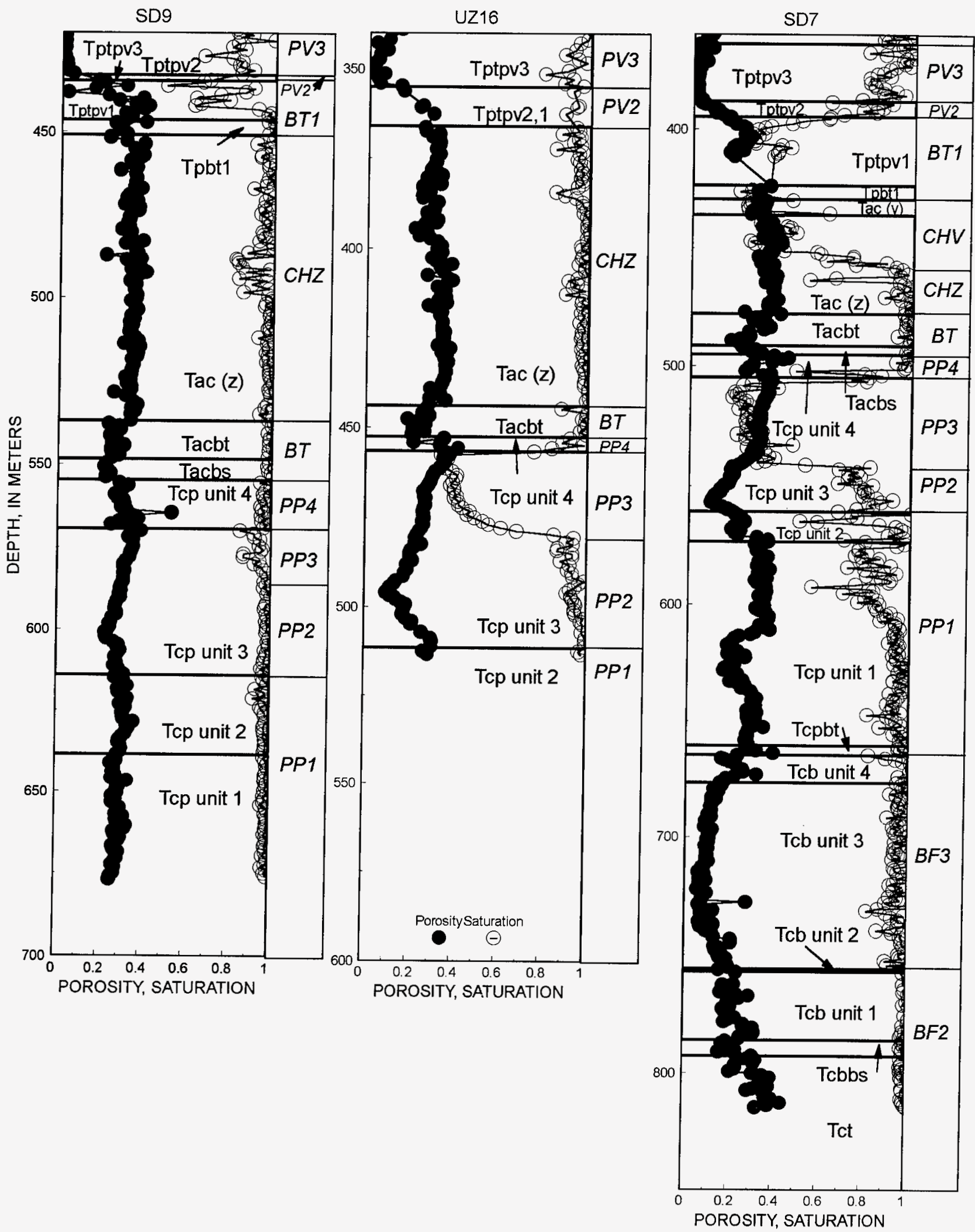

Figure 9. Oven-dry porosity and saturation profiles of rocks from the base of the Topopah Spring Tuff; the pre-Topopah Spring bedded tuff; the Calico Hills Formation; and the Prow Pass, Bullfrog and Tram Tuffs of the Crater Flat Group from boreholes SD9, UZ16, and SD7. 

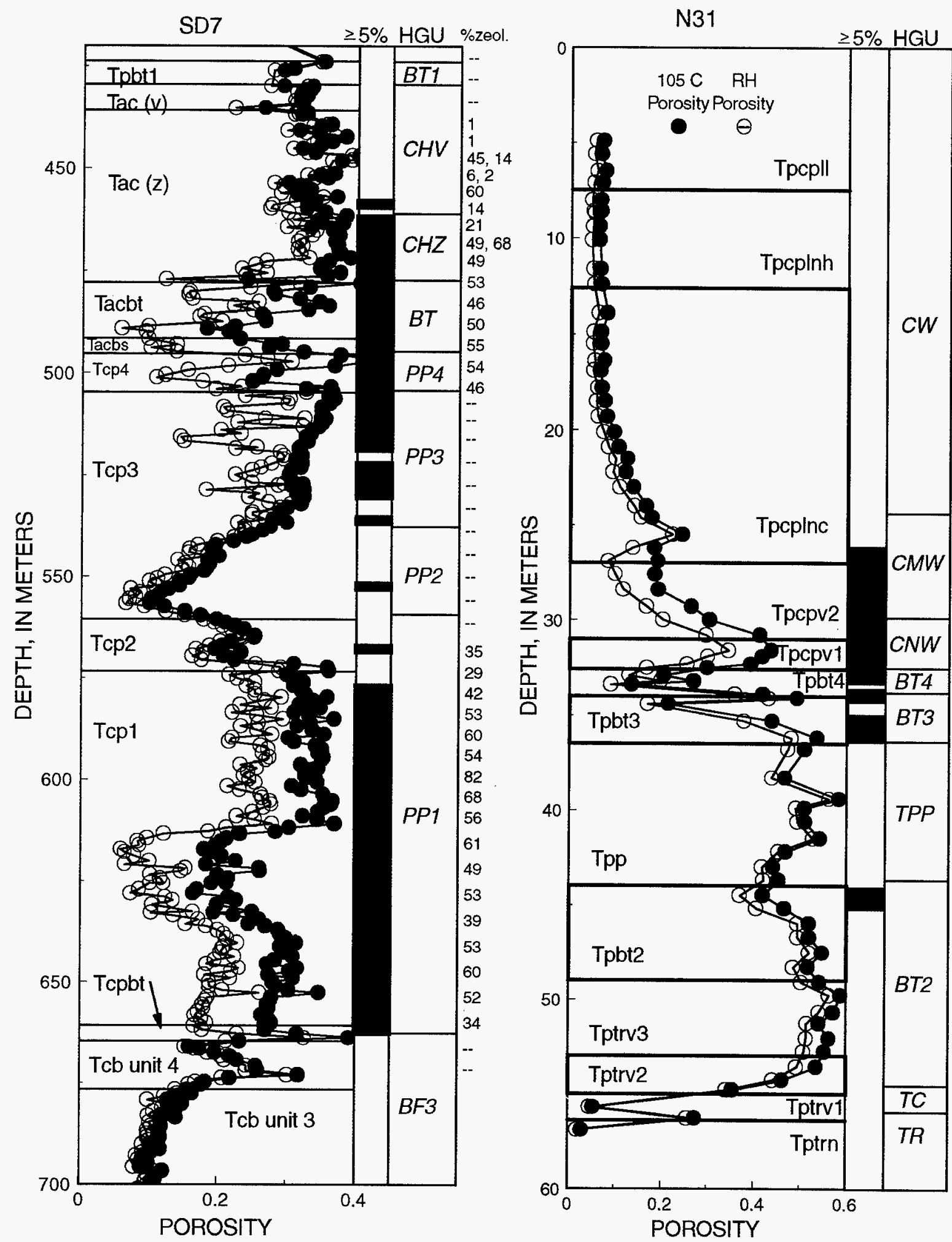

RESIDUAL WATER CONTENT (HGU) $5 \%$ OR GREATER

Figure 10. Porosity determined using standard oven drying and relative humidity oven drying for core from the Calico Hills Formation, Prow Pass Tuff, and part of the Bullfrog Tuff in SD7 and for core from the lower part of the Tiva Canyon Tuff to the upper part of the Topopah Spring Tuff in borehole N31. 
lower one-half of unit 3 and is welded, devitrified, unaltered, and lower in porosity; and $\boldsymbol{P P 1}$, which is composed of Tcp 2 and Tcp 1 , both of which are zeolitized. The boundary between PP 3 and PP2 varies among the four boreholes penetrating Tcp3, but the direct approach of dividing the unit in two halves seems to adequately minimize the variance.

The Bullfrog and Tram Tuffs were only penetrated by SD7 and have been divided only on the basis of alteration character. The hydrogeologic units are $\boldsymbol{B F 3}$, which is the unaltered units 4 and 3 of the Bullfrog Tuff, and $\boldsymbol{B F} 2$, which is the slightly altered units 2 and 1 of the Bullfrog Tuff, the underlying basal sandstone, and the altered samples of the Tram Tuff.

\section{Phase 2: Alteration, Microfractures, and Permeability}

Water is stored in, and flows through, the interconnected pores of the rock matrix; therefore, porosity is useful for characterizing the hydrologic character of the various rock types. In general, the porosity can be related primarily to the depositional features and amount of welding of a rock, with the lowest porosity in the most densely welded rocks and the highest porosity in the nonwelded and bedded rocks. For many rocks, the porosity is also related to alteration history because clays, zeolites, opal, and calcite form in place or are deposited in pore channels and throats and, therefore, may decrease porosity. Occurrence of clay or zeolite zones only slightly reduces the measured porosity because water can be stored in clay and zeolite mineral structures rather than occupy space within the pores (which would reduce the measured porosity). This is true unless water is held in smectites that swell with the incorporation of water to as much as 300 times their original size, thus reducing the porosity. Clays and zeolites do influence the pore-size distribution and, thus, the character of the moisture-retention curve and the permeability. Rocks containing clay or zeolites can maintain a relatively large volume of water, but by holding it tightly within clay structures, small pores, or pore throats, the permeability is reduced. Zones with clay or zeolites may be an important factor contributing to perched water. Borehole SD7 has a saturation profile (fig. 9) in the rocks below the Topopah Spring Tuff (Tpt) that strongly indicates, by high saturations, the presence of alteration minerals and their ability to store water and influence its downward transmission. In zones where there is little or no alteration, such as in the vitric rocks of the Calico Hills Formation (Tac, CHV) and some of the devitrified and vapor-phase corroded rocks of the Prow Pass Tuff (Tcp, PP3), the saturations are extremely low because the pores are larger and drain more easily. In the crystallized and minimally vapor-phase-corroded Prow Pass Tuff (PP4, PP2, and PP1), the saturation is high because the rocks are welded with small pores. There is also some evidence that indicates an influence of some of the high-temperature alteration products, such as the vapor-phase crystallization minerals tridymite and cristobalite, on the retention of water in this zone.

Residual water content is defined as that water content for which the gradient $(\mathrm{d} \theta / \mathrm{d} \psi$; where $\theta$ is water content and $\psi$ is water potential) becomes zero (van Genuchten, 1980). It has alternatively been suggested as that point in saturation where liquid flow stops due to discontinuous columns of water, and vapor flow begins. This value is generally used as the dry-end fit parameter for moisture-retention curves and its magnitude will greatly influence the prediction of unsaturated hydraulic conductivity at low water contents. The water left in a rock at very low saturation will be in the smallest pores or channels or within mineral structures such as clays or zeolites. The volume of water remaining will then be indicative of either the quantity of very small pores or channels or the presence of waterabsorbing minerals such as clays or zeolites. Bush and Jenkins (1970) determined that drying rock samples in an oven at a temperature of $60^{\circ} \mathrm{C}$ and 40 percent relative humidity maintained water within the clay structures, as well as 1-2 molecular layers of water adsorbed to their surface, while removing it from the pore channels. Studies done on soils indicate that residual water content can be defined by the amount of water left in the pores after equilibrating in an environment of approximately -700 bars water potential, or about 65 percent relative humidity (Jackson, 1963; Rose, 1963). The influence of alteration, whether it be clays, zeolites, or vapor-phase minerals, on pore structure and water-holding capacity can be examined more closely by varying the relative humidity and temperature of the drying oven during the processing of the samples for the determination of porosity.

Rock samples were dried at $60^{\circ} \mathrm{C}$ and 65 percent relative humidity and at $105^{\circ} \mathrm{C}$ and ambient relative humidity ( $<20$ percent), and porosity was calculated using both dry weights (fig. 10). The altered rocks, 
such as Tacbt, Tacbs, Tcp4, and Tcp1, have porosity calculated from relative-humidity-dried rocks that is much lower, presumably because the water was held in the altered minerals. Values of the percentages of measured zeolite (in the form of clinoptilolite) (Chipera and others, 1996) are indicated (fig. 10). In locations in SD7 where there are no measured zeolites (indicated by "-.-"), yet there is a 5-percent differential porosity (indicated by the black bar), there are elevated quantities of vapor-phase minerals tridymite and cristobalite (Chipera and others, 1996). Cristobalite is present from depths $502.3 \mathrm{~m}$ to $569.4 \mathrm{~m}$ ( 2 to 35 percent), and tridymite is present from $502.3 \mathrm{~m}$ to $538.4 \mathrm{~m}$ ( 1 to 6 percent). The 5 -percent differential porosity typically occurs in rocks where zeolites were measured. It does not occur in the rocks where zeolites were not measured but where only cristobalite was present (538.4 $\mathrm{m}$ to $569.4 \mathrm{~m}$ ), but it did occur in the rocks located at the depths where there were both tridymite and cristobalite, indicating a possible influence of certain vapor-phase minerals, possibly tridymite or the combination of both, on the structure or geometry of the pore spaces and increasing the moisture-retention capacity of these rocks at low saturations. The increase in tortuosity of the flow channels due to the presence of clay, zeolites, or vapor-phase minerals also reduces the permeability, which is discussed below. [There is evidence that very high percentages of Opal-CT, which is a disordered silica phase containing both cristobaliteand tridymite-like structural units (Bish and Chipera, 1989), which are often found in the pre-Calico Hills bedded tuff (Tacbt), may influence the hydrologic character of rocks by reducing the permeability even more than the presence of zeolites.] The method of determining porosity from $\mathrm{RH}$ drying and comparing it to porosity determined from standard oven drying has been shown to be useful in classifying rocks into zones that have similar properties, such as permeability and moisture-retention characteristics, for the development of distinct model layers. It also may provide parameters useful in modeling as the measurements of all the physical properties using RH drying better reflect field conditions and are suggested for use in the interpretation of geophysical logs.

Hydrogeologic properties similar to those in SD7 that result in the 5-percent differential porosity, are apparent in rocks near the base of the Tiva Canyon Tuff, Tpcpv, and are exemplified in N31 (fig. 10). This zone of differential porosity, which, based on quantitative mineralogy from similar stratigraphic position, contains up to 35 percent smectite, is pervasive across the site, although to varying degrees (Bish and Chipera, 1989). The extent of the alteration appears to be related to the topographic location of the borehole; for example, boreholes situated in narrow up-wash channels may receive more frequent runoff and, therefore, can maintain higher water contents for longer periods of time (Flint and Flint, 1995). This zone of differential porosity at the base of the Tiva Canyon Tuff, which occurs within the CMW unit, is an important hydrologic feature because it may accentuate the capillary barrier effect caused by small pores situated above large pores at this transition into the nonwelded tuffs. The differential porosity appears through the base of the BT3 hydrogeologic unit, but the combination of very large porosities and the particular pore-size distributions of the units below the CMW, despite the presence of clay, results in the drainage and relatively low saturation of these units.

Another measurement method that gives insights into the structure or sizes of pores and the influence of clays and zeolites is the determination of particle density using helium pycnometry. A selection of various lithologic types from UZ16 was analyzed using water saturation to calculate particle density from bulk density and porosity and helium pycnometry to directly measure the volume of the solid particles of the rock to calculate particle density (fig. 11). These samples included vitric bedded tuff, zeolitized bedded tuff and nonwelded to moderately welded rocks, vitric densely welded rocks, and crystallized moderately to densely welded rocks. The moderately to densely welded, devitrified rocks (welded crystallized in fig. 11) lie close to the 1:1 line and have particle densities of approximately 2.55 to $2.6 \mathrm{~g} / \mathrm{cm}^{3}$, and rocks with abundant vapor-phase minerals will be closer to 2.5 because those minerals are approximately $2.3 \mathrm{~g} / \mathrm{cm}^{3}$ (fig. 11). The welded devitrified rocks do not respond differently to water or helium, so there is a 1:1 relation. Densely welded, vitric rocks, which include Tptpv3, are approximately $2.38 \mathrm{~g} / \mathrm{cm}^{3}$ (supported by Scott and others, 1983) when calculated using water saturation. The porosity in these rocks is extremely small, as are the pores (inferred by the moisture-retention curve, fig. 13f) and the occupation of these pores by helium, when voided of water for the pycnometry measurement, may be limited by the nonpolarity of the helium molecule. In addition, vitric rocks typically contain as much as 5 percent water (D.C. Buesch, U.S. Geologi- 


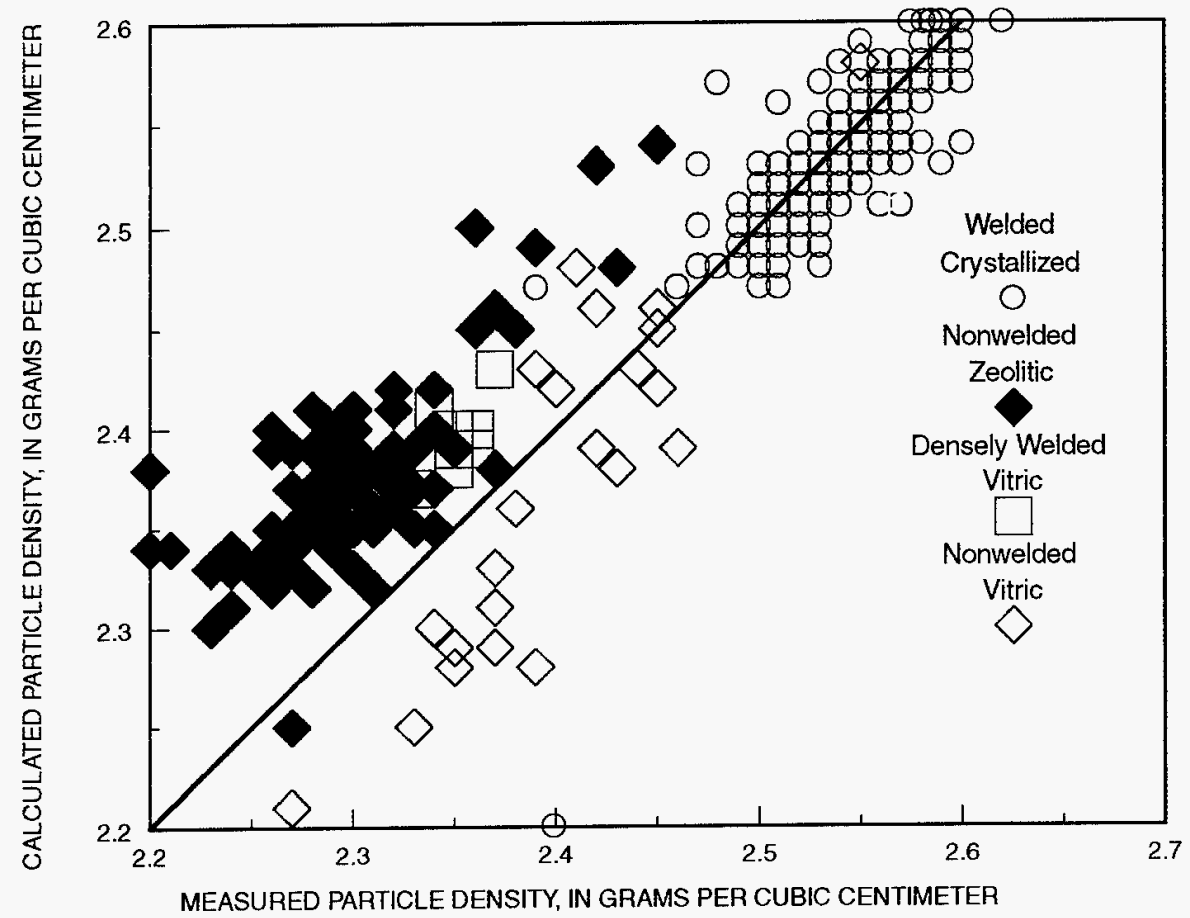

Figure 11. Calculated particle density using water saturation versus particle density measured using helium pycnometry for nonwelded to densely welded tuffs that are vitric, crystallized, or zeolitized on samples from borehole UZ16. 

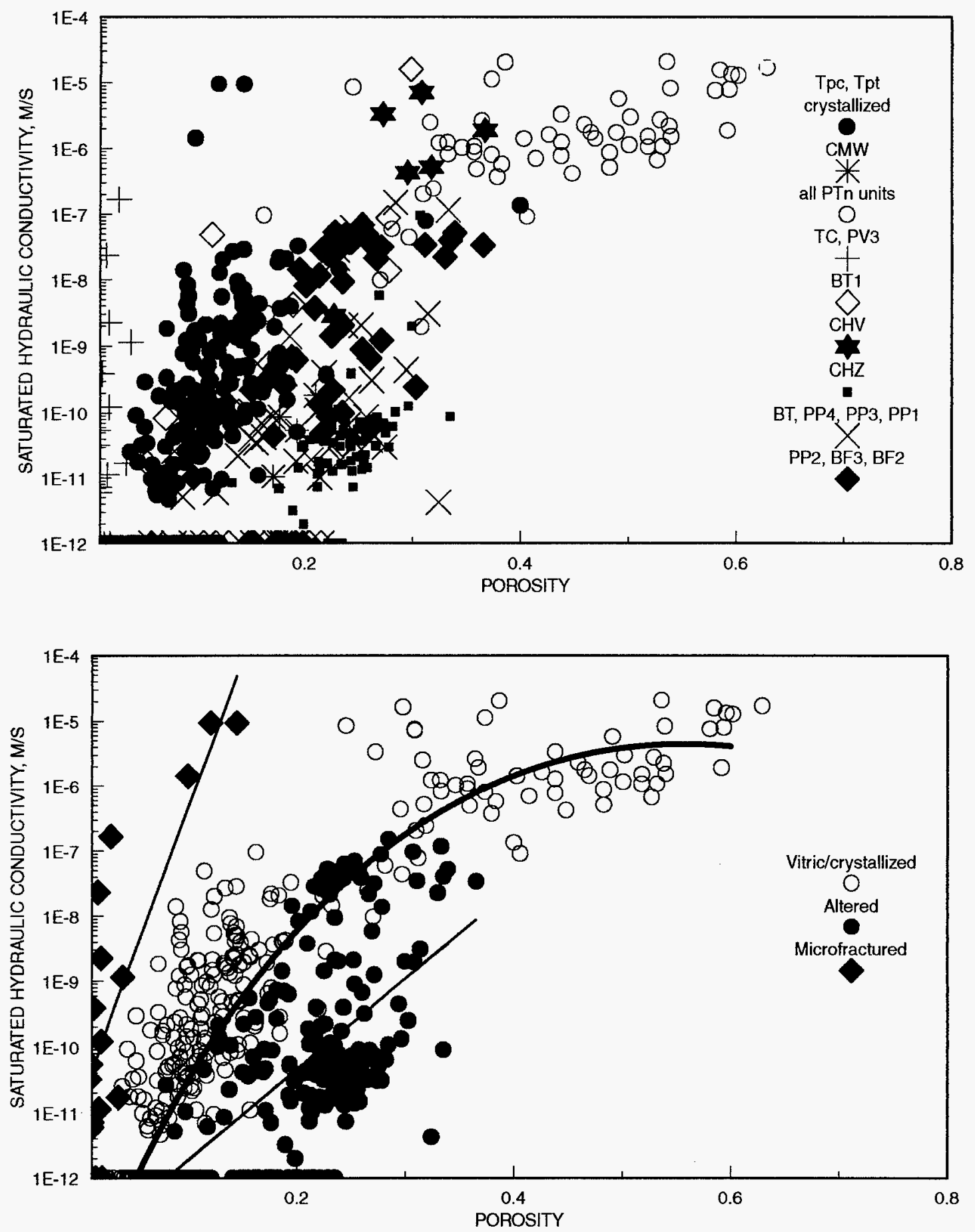

Figure 12. Relation of porosity and saturated hydraulic conductivity for samples grouped (a) by various hydrogeologic units and (b) by vitric/crystallized, altered, and microfractured units. 

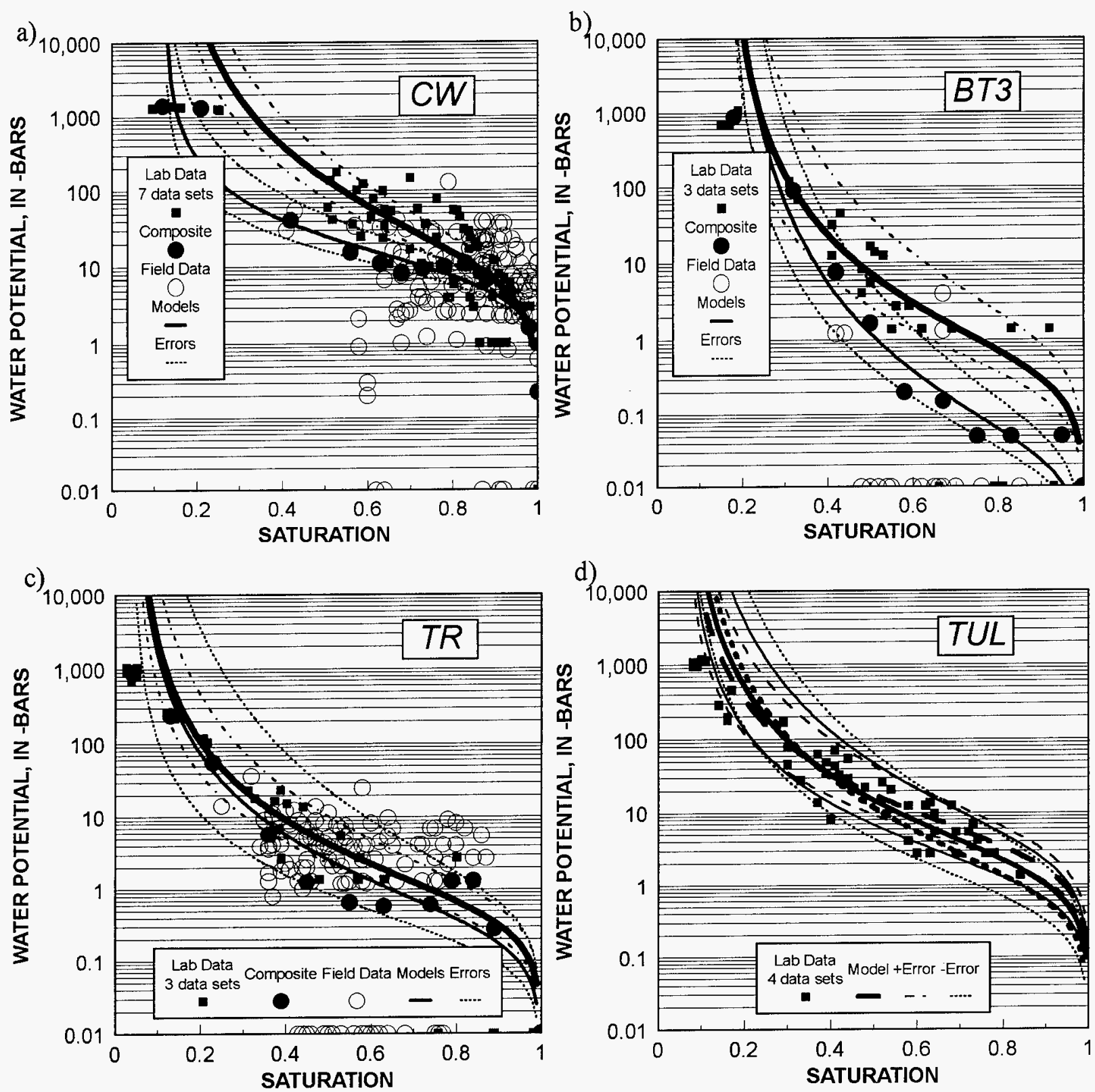

Figure 13. Moisture-retention curves for core samples from hydrogeologic units (a) CW, (b) BT3, (c) TR, (d) TUL, (e) TMN, (f) PV3, (g) CHZ, and (h) PP2. All units have laboratory measurements of core whereas units CW, BT3, and TR have field measurements included. 

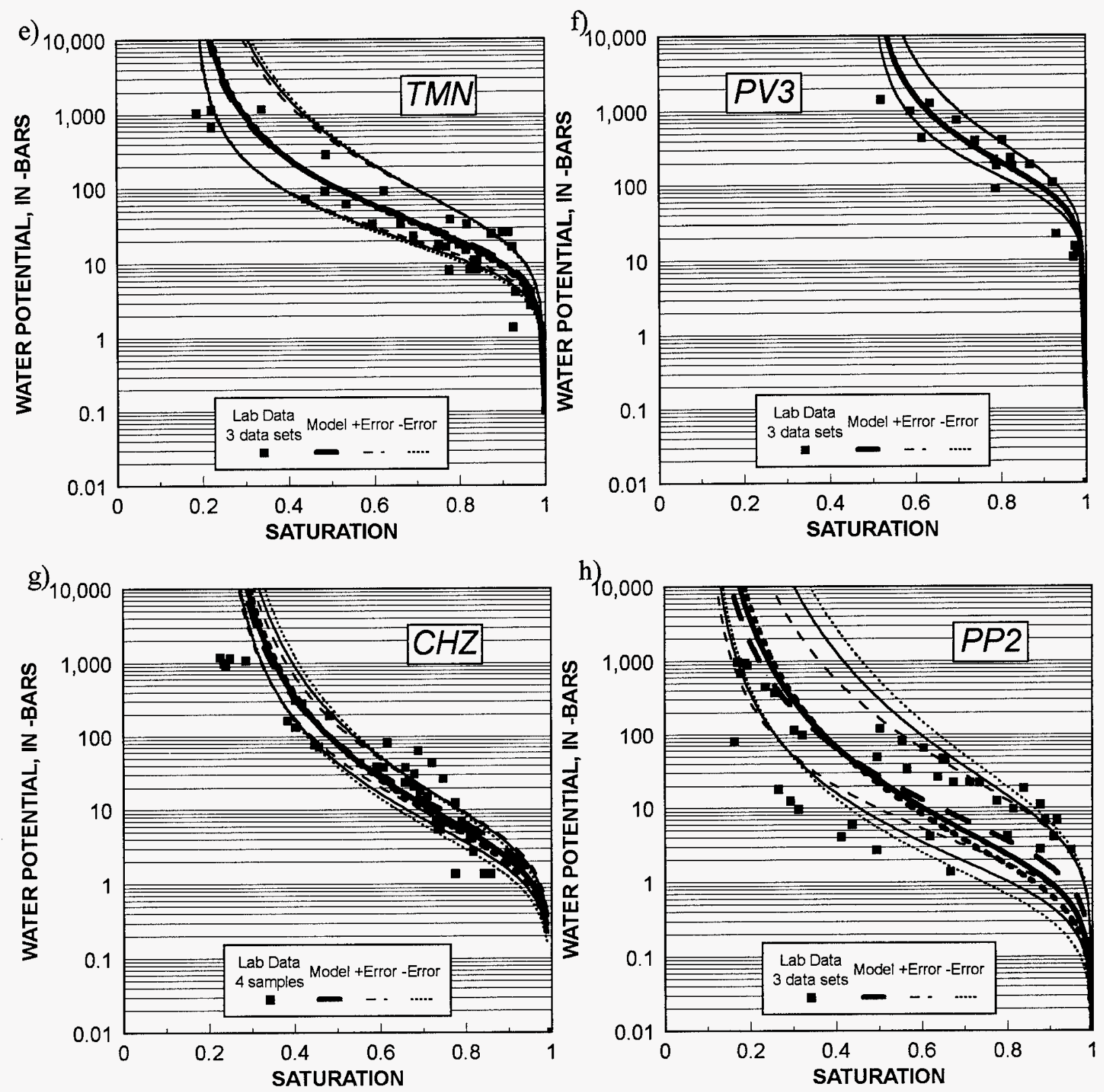

Figure 13. Moisture-retention curves from laboratory measurements of core for hydrogeologic units (e) TMN, (f) PV3, (g) $\mathrm{CHZ}$, and (h) PP2. - Continued 
cal Survey, written commun., 1996), which would be dehydrated prior to the pycnometry measurement and not replaced by the helium due to the nonpolarity, thus underestimating the particle density. Particle densities for the densely welded vitric rock samples are approximately $0.045 \mathrm{~g} / \mathrm{cm}^{3}$ lower using the helium pycnometry method. The nonwelded vitric and zeolitic samples have a larger range of particle densities, incorporating zeolites (particle density of $2.16 \mathrm{~g} / \mathrm{cm}^{3}$ for clinoptilolite), and in the vitric samples, smectites (particle density of $2.5 \mathrm{~g} / \mathrm{cm}^{3}$ ). These two minerals result in varying responses of the samples to the different measurement techniques due to their structural character. Zeolitic samples are approximately $0.08 \mathrm{~g} / \mathrm{cm}^{3}$ lower in particle density when measured using pycnometry, and the nonwelded vitric samples, which contain from 0 to 18 percent smectite (mostly in the form of montmorillonite) (Chipera and others, 1994), are an average of $0.06 \mathrm{~g} / \mathrm{cm}^{3}$ higher. Zeolites contain 1.5 to 3 times the water of glass in a high relative humidity environment, yet do not exhibit significant swelling. This adsorbed water (due to ion-dipole interactions) and zeolite water (in-filling channels and cages in the crystal-lattice framework) can be removed at temperatures of 70 to $300^{\circ} \mathrm{C}$ (Martin and others, 1991). [Bound water (covalent and hydrogen bonds within the crystal structure) is removed at temperatures of greater than $260-600^{\circ} \mathrm{C}$.] Montmorillonite has adsorbed and interstitial water that can increase the interlamellar spacing of the mineral from 10 to 19 angstroms (Deer and others, 1966), resulting in volume changes up to 300 times the dehydrated size of the mineral. Based on measurements of standard thermal dehydration curves of montmorillonite (Nutting, 1943), Gardner (1965) suggests temperatures of $165-175^{\circ} \mathrm{C}$ be used to remove adsorbed and interstitial water from clays, and Bush and Jenkins (1970) suggest it requires $180^{\circ} \mathrm{C}$ to remove all unbound water. During water saturation measurements, adsorbed and interstitial water occupies space within the zeolite and clays, as well as within the pore spaces. The samples were dried at a temperature of $105^{\circ} \mathrm{C}$ and some, but not all, water was removed from the zeolites, clays, and pore spaces. Because helium sorbs to neither zeolite nor clay (Martin and others, 1991) when added to the samples during the pycnometry measurement, it occupies the pore spaces, but does not occupy the spaces within the zeolite and clay minerals. This results in a lower measured particle density for the samples with zeolites. The nonwelded, vitric samples with clays, however, respond differently because of the large swelling capacity of the montmorillonite (Iwata and others, 1988; Deer and others, 1966). When dried, the removal of water results in a collapse of the clays (Bish, 1989), reducing the clay volume to a greater degree than the actual volume of water removed (Iwata and others, 1988). Therefore, the weight of the sample is reduced less than the corresponding increase in volume, which is filled by helium, and the calculation of particle density for the clay samples is higher for the helium pycnometry measurement than for the water saturation method.

The effects of alteration materials on the hydrologic character of the rocks were evaluated by comparing the porosity with the measured $K_{s}$ for 593 samples from all lithostratigraphic units (fig. 12). The upper figure shows the relation of the $\log$ of $K_{s}$ to porosity for samples grouped by hydrogeologic unit. The most obvious outliers are those from the zeolitized rocks in the Calico Hills Tuff (CHZ) that have a relatively high porosity but a very low conductivity. Samples from the crystal-rich and crystal-poor vitrophyres of the Topopah Spring Tuff (Tptrv1, TC and Tptpv3, PV3) have very low matrix porosities yet have several samples with high conductivities resulting from microfractures. It is possible that some of these samples with low values of $K_{s}$ had microfractures, but they were filled with alteration materials. Three crystallized and welded samples from Tptrn, Tptpul, and Tptpln, with fairly low porosity yet with high conductivity, contained visible microfractures. The correlation between lithostratigraphic features and properties such as porosity and conductivity is exemplified by simply plotting the data as vitric/crystallized, altered, and microfractured (fig. 12). The microfractured category includes TC and PV3, plus the three welded samples with the visible microfractures that do not represent the matrix permeability. The "altered" category includes all lithostratigraphic units below the vitric/zeolitic boundary (BT1a, CHZ, BT, PP4, PP3, PP2, PP1, BF3, and $\mathrm{BF} 2$ ), plus the $\mathrm{CMW}$, and the vitric/crystallized category includes all remaining hydrogeologic units. The "altered" category is crudely defined, because there are crystallized and unaltered zones within this category, but was selected for simplicity to aid in the application of predictive equations. Relations between these simplified, lithostratigraphic, feature-based categories, porosity, and conductivity can be represented by regression models developed using all measured 
samples (table 6; fig. 12). (There is not enough spatial representation for all of the units included in the "altered" grouping for these units to be divided accurately into unique hydrogeologic units represented by alteration alone, and for appropriate characterization, they need to be better sampled.) Regression models were used to estimate $K_{s}$ on the remaining 4,300 unmeasured samples, some of which included samples with conductivities too low to measure (less than $5 \mathrm{x}$ $10^{-12} \mathrm{~m} / \mathrm{s}$ ) with the current laboratory technique. The estimates provide a representation of $K_{s}$ of the densely welded tuffs, as well as providing estimates of matrix permeability on samples with microfractures for prediction of unsaturated hydraulic conductivity. These microfractured samples are likely to only have high conductivities when saturated and, after the fractures drain, they have relatively no flow.
The hydrogeologic units at the vitric/zeolitic boundary vary spatially over the mountain. In the southern part of the site where the boundary is as much as $140 \mathrm{~m}$ below the Tptpv3, the upper parts of the Calico Hills Tuff, Tpbt1, Tptpvl, and Tptpv2 are unaltered. This condition exists in only two boreholes sampled, SD7 and SD12. Remaining boreholes are in locations to the north and east where the vitric/zeolitic boundary is typically defined at the base of Tptpv3, with zeolitization along the fractures in that unit. Properties for the BT1 hydrogeologic unit, which includes Tptpv1 and Tpbt1, have been characterized for both altered and unaltered samples, BT1a and BT1, respectively.

Table 6. Regression equations used to predict saturated hydraulic conductivity and moisture-retention curve-fit parameter, $\alpha$, from porosity

\begin{tabular}{lc}
\hline Altered (CMW, BT1, CHZ, BT, PP4, PP3, PP2, PP1, BF3, and BF2) \\
\hline $\log$ (saturated hydraulic conductivity) & $-13.1+13.8$ (porosity) \\
Standard error of y estimate & 1.25 \\
$\mathrm{r}^{2}$ & 0.28 \\
number of observations & 206 \\
$\log (\alpha)=-2.9+8.2$ (porosity) & \\
Standard error of y estimate & 0.65 \\
$\mathrm{r}^{2}$ & 0.32 \\
number of observations & 10 \\
Microfractures (TC, PV3) & \\
\hline $\log$ (saturated hydraulic conductivity) $=-10.8+45.1$ (porosity) \\
Standard error of y estimate & 1.40 \\
$\mathrm{r}^{2}$ & 0.66 \\
number of observations & 17 \\
& \\
Remaining vitric and crystallized (CCR, CUC, CUL, CW, CNW, BT4, TPY, BT3, TPP, \\
BT2, TR, TUL, TMN, TLL, TM2, TM1, PV2, BT1, CHV) \\
\hline $\log$ (saturated hydraulic conductivity) =-14.2 +69.0 (porosity) - 63.3 (porosity) ${ }^{1.3}$ \\
Standard error of y estimate & 1.00 \\
$\mathrm{r}^{2}$ & 0.80 \\
number of observations & 371 \\
$\log (\alpha)=-2.0+28.6$ (porosity) -28.6 (porosity) & \\
Standard error of y estimate & 0.48 \\
$\mathrm{r}^{2}$ & 0.74 \\
number of observations & 21 \\
\hline
\end{tabular}




\section{Phase 3: Moisture Retention and Predictions of Field Water Potentials}

Moisture-retention curves are represented for eight hydrogeologic units in figure 13a-h. The first three units (fig. 13a-c) represent both laboratory desorption curves and composite curves combining laboratory data and all field data that was measured from each hydrogeologic unit. Standard errors of the curvefit parameters, $\alpha$ and $n$, were used to include the 66-percent confidence intervals about the curve-fit models. These intervals were used for graphical purposes because the lower limits of the 95-percent intervals were undefined for a number of the hydrogeologic units. Two models were developed: one model is associated with the laboratory desorption data (thick solid line in fig. 13a, b, and c) and the second model is associated with the composite data set (thinner solid line). In all three units, the composite model was lower as a result of including field data that had lower water contents for given water potentials than the desorption data. This results in slightly wetter air-entry values (lower $\alpha$ ), which increases modeled fluxes for the same matrix saturation.

The remaining five hydrogeologic units (fig. 13d-h) are data sets from laboratory desorption measurements only and include the error incorporated into the laboratory measurement due to the instrument resolution. This analysis was conducted on data from the first three curves (fig. 13a-c), but not incorporated into those figures for purposes of graphical clarity. The values are included in table 8 . The curves representing the instrument error are included on the remaining figures (fig. 13d-h) and represent an upper and lower bound. Various hydrogeologic units are represented by different numbers of individual samples on which measurements were made to produce individual curves, so the relative degree of scatter in the points may be somewhat misleading. Several of the curves not shown only had one sample; therefore, the resulting error in the fit parameters is very low. On the other hand, for example, the difference between the CHZ and PP2 is a function of the relative vertical heterogeneity in the unit, which is low in the CHZ and high in the PP2. In an effort to represent an entire unit with one curve, all samples are included and the curve-fitting process smoothes out the extremes, which are then expressed by the standard errors.

Notable differences in the moisture-retention curves (fig. 13) are chiefly a function of the pore-size distributions of the rock types. These different distributions are primarily due to degree of welding and are exemplified by comparing the curve for the bedded tuff (BT3) to those of the welded tuffs, CW, TUL, TMN, and PV3 (fig. 13). These welded tuff units all have high air-entry pressures, approximately equivalent to $1 / \alpha$, and describe the water potential at which the pores initially drain, and thus are the largest pores. Rocks in the hydrogeologic unit TR are vapor-phase corroded, which increases the size of the pores and results in pore structures that drain at lower water potential than in other noncorroded welded rocks. Another notable feature is the residual saturation, which is approximately represented by the saturation at which the dry end of the curves becomes asymptotic. It is related to the abundance of very small pores that retain water at approximately 60 -percent relative humidity or -700 bars. Altered rocks, such as $\mathrm{CHZ}$, or vitrophyres, such as PV3, have the largest residual saturations. There are also observable differences between the lithophysal and nonlithophysal units, TUL and TMN, with the nonlithophysal unit having a greater abundance of small pores.

The $\log$ of $\alpha$ is well correlated to porosity for the unaltered vitric, crystallized, and microfractured samples (fig. 14). The correlation is not as good for the altered samples. Regression models were done for the prediction of $\log$ of $\alpha$ that was determined for all hydrogeologic units (table 6) for the purposes of estimating parameters from porosity. This is useful for the development of more gradual transition zones in numerical models (Glass and others, 1994) to eliminate the lateral diversion of water due to model artifacts that are a result of model layers that are unrealistically contrasting in flow properties (Flint and others, 1996a; Moyer and others, 1996). The form of the model equation for the relation of $\log$ of $\alpha$ to porosity is the same as for $K_{s}$ for both altered and unaltered hydrogeologic units.

For core samples from boreholes SD7, UZ14, and SD9, water potential was estimated from saturation data using equations 3 and 4 for each hydrogeologic unit and compared to measured water-potential values (fig. 15). Water-potential and saturation values corrected for water loss due to evaporation were used. Matches are relatively good for most zones, with the exception of the Calico Hills (Tac) in UZ14 and SD9 and the lower part of the Prow Pass Tuff (Tcp) in SD7. The moisture-retention curves for the Calico Hills were 


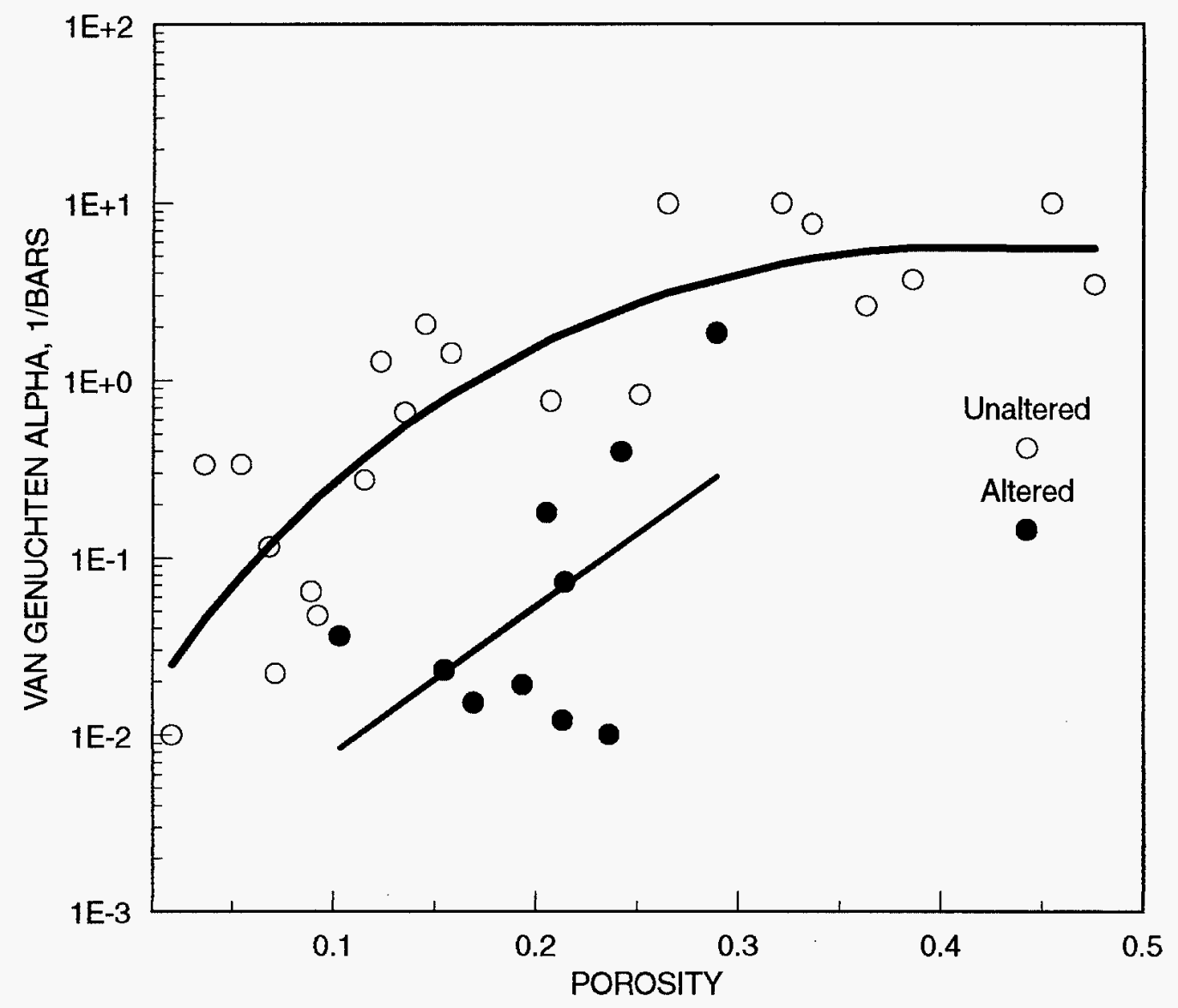

Figure 14. Relation of log of moisture-retention curve-fit parameter, van Genuchten alpha, to porosity. 

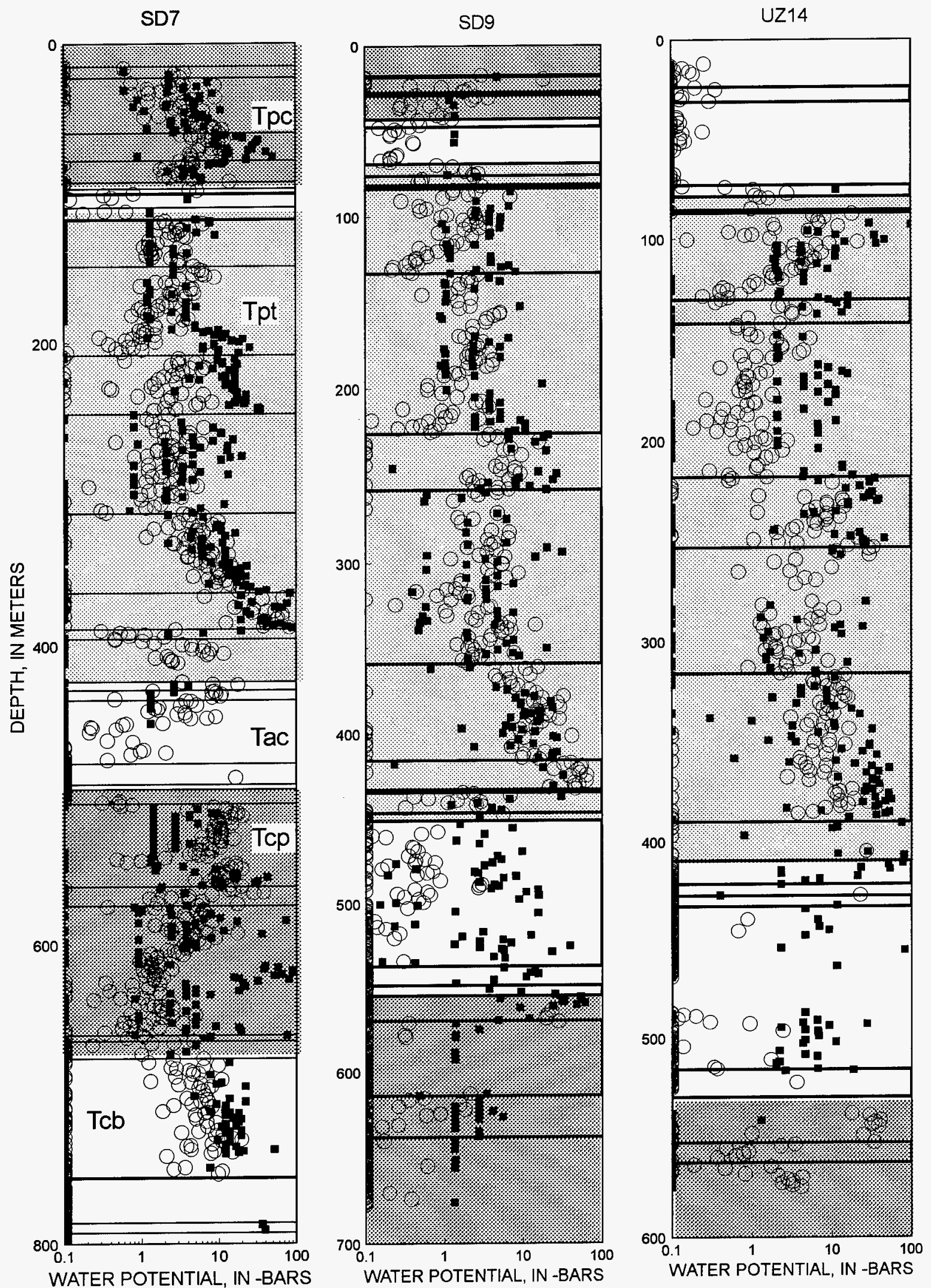

Figure 15. Measured (squares) and estimated (circles) water potential using moisture-retention parameters for boreholes SD7, SD9, and UZ14. 
measured on samples from UZ16, which does not well represent the two boreholes farthest away (SD9 and UZ14), but matches the data from SD7 better. The curves for the lower part of the Prow Pass Tuff (Tcp) were determined from samples from SD9, which does not match the measurements in SD7. These discrepancies are probably due to the inability to adequately represent the lateral heterogeneity of these units on the basis of measurements from one borehole and support the contention that there is lateral variability in the Calico Hills Formation and in the Prow Pass Tuff, which is difficult to substantiate with physical properties because few boreholes penetrated these units. In all deep boreholes, it was noted that a division was necessary in the Topopah Spring Tuff lower nonlithophysal unit, TM. The unit was divided into an upper twothirds, TM2, and a lower one-third, TM1, primarily on the basis of moisture-retention characteristics and partly on differences in $K_{s}$. This division and development of an additional moisture-retention curve for the lower one-third of the unit aided in matching the waterpotential measurements for all the deep boreholes.

This was not the case for the Prow Pass Tuff. Although litho-stratigraphic contacts did not provide hydrogeologic units that had consistent properties among all five measured boreholes, there were no additional divisions, aside from the one in PP3, which was made based on degree of vapor-phase alteration, that could be made that would reduce the variance in properties for all boreholes.

\section{Phase 4: -Statistical Analysis to Produce Mean Values for Modeling Parameters}

Once all the measured data were compiled, along with the estimated $K_{s}$ from the regression analysis, mean values and standard deviations were calculated for each property for each hydrogeologic unit (table 7). Minor adjustments were made in boundaries on the basis of porosity, such as the upper units and near the base of the Tiva Canyon Tuff. In general, the variation in porosity within each hydrogeologic unit was relatively small, with the exception of BT4, BT2, and PV2. BT4 is very thin, and few samples were collected. The relatively variable properties in BT2 result from being composed of four units in Tpbt2 and Tptrv3 (Moyer and others, 1996) that vary in the amount of argillization and include Tptrv2 that grades rapidly into low porosity rocks; thus, few low-porosity samples are rep- resented. The same mixture of properties is true for PV2 that grades relatively sharply from very low to relatively high porosity.

Several trends emerge from comparing the mean values of porosity for the hydrogeologic units. In the Tiva Canyon Tuff, the lithophysal CUL is twice as high in mean porosity (16 percent) as the mostly nonlithophysal CW (8 percent). The Topopah Spring Tuff (Tpt) does not differ as much with the upper (TUL) and lower (TLL) lithophysal units having mean porosities of 15 percent and 13 percent respectively, whereas the upper and lower nonlithophysal units (TMN, TM2 and TM1) are 11 percent, 11 percent, and 9 percent, respectively. The vitric bedded tuffs and nonwelded ignimbrites in the PTn, included in CNW, BT4, BT3, and $\mathrm{BT} 2$, vary in mean porosity from 39 percent to 49 percent. These porosities are significantly higher than similarly deposited vitric tuffaceous rocks in BT1 and $\mathrm{CHV}$ that have mean porosities of 27 percent and 34 percent, respectively. All units below the Topopah Spring Tuff have moderate to high mean porosity (26 percent to 35 percent), except for BF3, which is 12 percent. Frequency distributions of porosity are shown for each hydrogeologic unit in Appendix I and indicate normal distributions for most units.

Mean water content, saturation, and water potential have been calculated (table 7), but several factors must be considered to help explain these values. Spatial averaging of water content, saturation, and water potential is not realistic based on consideration of the spatial distribution of infiltration that results from the distribution of precipitation, the varying thickness of alluvial cover, the topographic positions of boreholes, and the variable thickness of shallow rock units with different properties (Flint and Flint, 1994; Flint and Flint, 1996).

Variances are also a function of spatial distribution of alteration features or sampling of microfractures. Large variances are noted in the hydrogeologic unit CMW, as the argillic alteration is likely to be variable among samples vertically and laterally between boreholes, and in TC due to the random sampling of microfractures. Means of $K_{s}$ calculated using the power law with $w$ equal to -0.4 are generally slightly lower than those calculated using a geometric mean. Geometric means calculated for $K_{s}$ estimated from regression analyses are frequently lower than those calculated using measured values. This is particularly true for samples with microfractures because the conductiv- 


\begin{tabular}{|c|c|c|c|c|c|c|c|c|c|c|c|c|c|c|c|c|c|c|c|c|c|c|c|c|c|c|}
\hline \multirow[t]{2}{*}{$\begin{array}{l}\text { Hydro- } \\
\text { geologic } \\
\text { unit }\end{array}$} & \multicolumn{2}{|c|}{$\begin{array}{c}\text { Relative } \\
\text { humidity } \\
\text { porosity } \\
\text { (v/v) }\end{array}$} & \multirow[t]{2}{*}{$\mathbf{N}$} & \multicolumn{2}{|c|}{$\begin{array}{c}\text { Bulk } \\
\text { density } \\
\left.\text { (g/( } \mathrm{cm}^{3}\right)\end{array}$} & \multicolumn{2}{|c|}{$\begin{array}{c}\text { Porosity } \\
\text { (v/v) }\end{array}$} & \multicolumn{2}{|c|}{$\begin{array}{l}\text { Particle } \\
\text { density } \\
\text { (g/cm })\end{array}$} & \multirow[t]{2}{*}{$\mathbf{N}$} & \multicolumn{2}{|c|}{$\begin{array}{c}\text { Volumetric } \\
\text { water } \\
\text { content } \\
(v / v)\end{array}$} & \multicolumn{2}{|c|}{ Saturation } & \multirow[t]{2}{*}{$\mathbf{N}$} & \multicolumn{2}{|c|}{$\begin{array}{c}\text { Water } \\
\text { potential } \\
\text { (bars) }\end{array}$} & \multirow[t]{2}{*}{$\mathbf{N}$} & \multicolumn{2}{|c|}{$\begin{array}{c}\text { Saturated } \\
\text { hydraulic } \\
\text { conductivity } \\
(\mathrm{m} / \mathrm{s})\end{array}$} & \multicolumn{2}{|c|}{$\begin{array}{c}\text { Saturated } \\
\text { hydraulic } \\
\text { conductivity } \\
(\mathrm{m} / \mathrm{s})\end{array}$} & \multirow[t]{2}{*}{$\mathbf{N}$} & \multicolumn{2}{|c|}{$\begin{array}{c}\text { Estimated } \\
\text { saturated } \\
\text { hydraulic } \\
\text { conductivity } \\
(\mathrm{m} / \mathrm{s})\end{array}$} & \multirow[t]{2}{*}{ N } \\
\hline & Mean & SD & & Mean & SD & Mean & SD & Mean & SD & & Mean & SD & Mean & SD & & $\begin{array}{l}\text { Geom. } \\
\text { mean }\end{array}$ & SD & & $\begin{array}{c}\text { Geom. } \\
\text { mean }\end{array}$ & SD & $\begin{array}{l}\text { Power } \\
\text { law } \\
\text { mean }\end{array}$ & SD & & $\begin{array}{c}\text { Geom. } \\
\text { mean }\end{array}$ & SD & \\
\hline$C C R$ & - & - & 0 & 2.39 & 0.07 & 0.062 & 0.020 & 2.55 & 0.04 & 9 & 0.046 & 0.015 & 0.75 & 0.13 & 9 & - & - & 0 & - & - & - & - & 0 & $1.5 \mathrm{E}-12$ & 2. 1E-12 & 29 \\
\hline cuc & 0.235 & 0.025 & 17 & 1.91 & 0.13 & 0.253 & 0.060 & 2.56 & 0.09 & 101 & 0.098 & 0.048 & 0.40 & 0.17 & 101 & - & - & 0 & $3.8 \mathrm{E}-082$ & $2.2 E-08$ & 3.3E-08 5 & $5.9 E-08$ & 3 & 3. $9 \mathrm{E}-08$ & $1.4 E-07$ & 101 \\
\hline CUL & 0.126 & 0.038 & 31 & 2.10 & 0.14 & 0.164 & 0.062 & 2.52 & 0.03 & 98 & 0.094 & 0.021 & 0.61 & 0.15 & 98 & - & - & 0 & $1.2 \mathrm{E}-08$ & - & $1.2 \mathrm{E}-08$ & - & 1 & 5.7E-10 & 1.2E-07 & 798 \\
\hline$C W$ & 0.066 & 0.026 & 405 & 2.30 & 0.06 & 0.082 & 0.030 & 2.51 & 0.05 & 599 & 0.064 & 0.026 & 0.80 & 0.14 & 599 & 8.8 & 8.9 & 183 & $5.4 \mathrm{E}-115$ & $5.2 \mathrm{E}-12$ & 4. $6 \mathrm{E}-111$ & $1.0 \mathrm{E}-10$ & 6 & $3.8 \mathrm{E}-12$ & 4. $1 \mathrm{E}-09$ & 599 \\
\hline$C M N$ & 0.140 & 0.044 & 61 & 1.97 & 0.14 & 0.203 & 0.054 & 2.47 & 0.06 & 90 & 0.185 & 0.062 & 0.90 & 0.13 & 90 & 0.9 & 16.0 & 13 & 5.0E-10 5 & $5.6 E-08$ & $1.6 \mathrm{E}-104$ & 4.7E-08 & 4 & 8. $8 \mathrm{E}-12$ & 1.0E-11 & 90 \\
\hline CNW & 0.300 & 0.088 & 59 & 1.46 & 0.17 & 0.387 & 0.070 & 2.38 & 0.10 & 101 & 0.259 & 0.081 & 0.69 & 0.24 & 101 & 0.2 & 0.5 & 25 & 3.1E-08 4 & 4. $1 E-06$ & $7.6 E-104$ & $4.8 E-07$ & 8 & 2.6E-07 & $2.2 E-06$ & 101 \\
\hline$B T 4$ & 0.369 & 0.120 & 24 & 1.31 & 0.29 & 0.439 & 0.123 & 2.34 & 0.14 & 33 & 0.220 & 0.097 & 0.51 & 0.19 & 33 & 0.1 & 0.0 & 5 & 1.6E-07 2 & $2.4 \mathrm{E}-04$ & $2.6 \mathrm{E}-096$ & $6.5 \mathrm{E}-06$ & 3 & 4.1E-07 & $1.8 E-05$ & 533 \\
\hline TPY & 0.234 & 0.082 & 37 & 1.79 & 0.23 & 0.254 & 0.082 & 2.40 & 0.11 & 43 & 0.163 & 0.046 & 0.68 & 0.20 & 43 & 0.1 & 0.0 & 9 & 3. $3 E-082$ & 2.0E-07 & $1.2 \mathrm{E}-082$ & $2.5 \mathrm{E}-07$ & 2 & 1.7E-08 & 7.4E-07 & 43 \\
\hline$B T_{3}$ & 0.353 & 0.079 & 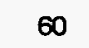 & 1.39 & 0.18 & 0.411 & 0.079 & 2.37 & 0.10 & 85 & 0.216 & 0.065 & 0.54 & 0.16 & 85 & 0.1 & 0.1 & 34 & 5.4E-07 1 & $1.2 E-06$ & 1.7E-07 2 & $2.3 E-06$ & 17 & 7.8E-07 & 1. $1 E-06$ & 685 \\
\hline TPP & 0.469 & 0.038 & 132 & 1.13 & 0.09 & 0.499 & 0.041 & 2.26 & 0.09 & 164 & 0.178 & 0.064 & 0.36 & 0.13 & 156 & 0.1 & 0.1 & 64 & 8.8E-07 4 & 4. $2 \mathrm{E}-07$ & 7.3E-07 6 & $6.7 \mathrm{E}-07$ & 10 & 3. $6 \mathrm{E}-06$ & $1.2 E-06$ & 6 164 \\
\hline BT2 & 0.464 & 0.093 & 118 & 1.20 & 0.26 & 0.489 & 0.105 & 2.37 & 0.23 & 171 & 0.185 & 0.069 & 0.39 & 0.15 & 171 & 0.3 & 0.7 & 41 & $3.2 \mathrm{E}-065$ & $5.6 \mathrm{E}-06$ & 8. $8 \mathrm{E}-079$ & $9.6 E-06$ & 19 & 1.7E-06 & $2.9 \mathrm{E}-06$ & 6171 \\
\hline TC & 0.042 & 0.036 & 50 & 2.38 & 0.10 & 0.054 & 0.036 & 2.51 & 0.04 & 66 & 0.034 & 0.024 & 0.62 & 0.17 & 66 & 9.4 & 186.7 & 21 & $7.6 \mathrm{E}-107$ & $7.5 E-09$ & $1.5 \mathrm{E}-101$ & $1.3 E-08$ & 3 & $6.2 \mathrm{E}-13$ & 7.1E-10 & 066 \\
\hline$T R$ & 0.146 & 0.034 & 435 & 2.15 & 0.08 & 0.157 & 0.030 & 2.55 & 0.03 & 439 & 0.078 & 0.019 & 0.51 & 0.13 & 439 & 1.2 & 4.5 & 159 & $1.7 \mathrm{E}-091$ & $1.6 E-07$ & $8.6 \mathrm{E}-101$ & $1.4 \mathrm{E}-06$ & 45 & $3.9 \mathrm{E}-10$ & $1.0 E-09$ & 9439 \\
\hline TUL & 0.135 & 0.032 & 455 & 2.13 & 0.08 & 0.154 & 0.031 & 2.51 & 0.02 & 455 & 0.108 & 0.022 & 0.72 & 0.15 & 455 & 1.4 & 4.7 & 246 & 2.0E-10 3 & $3.0 E-08$ & $9.7 \mathrm{E}-112$ & $2.5 E-07$ & 33 & 2.3E-10 & $5.2 \mathrm{E}-10$ & 455 \\
\hline TMN & 0.089 & 0.021 & 266 & 2.25 & 0.05 & 0.110 & 0.020 & 2.53 & 0.03 & 266 & 0.093 & 0.019 & 0.85 & 0.12 & 266 & 8.6 & 10.1 & 176 & 4. $0 E-114$ & 4. $3 E-11$ & $2.2 \mathrm{E}-114$ & $4.4 \mathrm{E}-10$ & 11 & 1.5E-11 & 2.3E-11 & 1266 \\
\hline$T L L$ & 0.115 & 0.032 & 453 & 2.21 & 0.17 & 0.130 & 0.031 & 2.54 & 0.17 & 453 & 0.101 & 0.024 & 0.78 & 0.14 & 453 & 1.3 & 3.6 & 253 & $2.3 E-102$ & $2.2 E-09$ & 8.7E-11 9 & $9.3 E-09$ & 43 & 7.0E-11 & 4. $5 \mathrm{E}-10$ & 453 \\
\hline$T M R$ & 0.092 & 0.033 & 225 & 2.27 & 0.08 & 0.112 & 0.031 & 2.56 & 0.03 & 225 & 0.095 & 0.026 & 0.85 & 0.10 & 225 & 3.0 & 9.2 & 157 & $9.6 \mathrm{E}-108$ & $8.8 \mathrm{E}-07$ & $1.9 \mathrm{E}-102$ & $2.4 \mathrm{E}-06$ & 15 & $1.8 \mathrm{E}-11$ & 2. $1 \mathrm{E}-09$ & 9225 \\
\hline$T M$ & 0.071 & 0.019 & 102 & 2.30 & 0.05 & 0.094 & 0.019 & 2.54 & 0.03 & 102 & 0.081 & 0.016 & 0.87 & 0.09 & 102 & 12.8 & 12.8 & 70 & $7.5 E-114$ & $4.5 \mathrm{E}-12$ & $6.5 \mathrm{E}-118$ & $8.2 \mathrm{E}-11$ & 2 & 4. $8 \mathrm{E}-12$ & $5.8 \mathrm{E}-12$ & 2102 \\
\hline PV3 & 0.020 & 0.018 & 89 & 2.27 & 0.26 & 0.036 & 0.039 & 2.36 & 0.25 & 89 & 0.034 & 0.039 & 0.88 & 0.14 & 87 & 4.9 & 66.2 & 70 & 5. OE-112 & 2.7E-10 & $2.6 \mathrm{E}-118$ & $8.5 E-10$ & 7 & $1.5 \mathrm{E}-13$ & 2.1E-12 & 289 \\
\hline PV2 & 0.123 & 0.079 & 39 & 1.96 & 0.25 & 0.173 & 0.106 & 2.37 & 0.03 & 39 & 0.148 & 0.107 & 0.84 & 0.16 & 39 & 3.3 & 15.9 & 30 & 7.3E-10 3 & $3.5 \mathrm{E}-08$ & $1.5 \mathrm{E}-102$ & $2.4 \mathrm{E}-08$ & 4 & $7.4 \mathrm{E}-11$ & 2.0E-07 & 39 \\
\hline BT1a & 0.193 & 0.077 & 36 & 1.66 & 0.16 & 0.288 & 0.072 & 2.34 & 0.05 & 36 & 0.267 & 0.076 & 0.93 & 0.16 & 36 & 0.3 & 1.6 & 29 & $5.4 \mathrm{E}-091$ & 1.6E-08 & $1.4 E-09$ & 4.3E-08 & 4 & $6.0 \mathrm{E}-11$ & 8.0E-10 & 36 \\
\hline BT1 & 0.265 & 0.065 & 43 & 1.66 & 0.14 & 0.273 & 0.067 & 2.28 & 0.07 & 43 & 0.083 & 0.020 & 0.32 & 0.10 & 43 & 0.1 & 0.4 & 43 & $1.6 \mathrm{E}-05$ & - & 1.6E-05 & - & 1 & $6.1 \mathrm{E}-08$ & 3. $2 E-07$ & $\begin{array}{ll}7 & 43\end{array}$ \\
\hline $\mathrm{CHV}$ & 0.321 & 0.037 & 69 & 1.47 & 0.06 & 0.345 & 0.034 & 2.24 & 0.10 & 69 & 0.168 & 0.078 & 0.50 & 0.24 & 69 & 0.2 & 0.2 & 62 & $5.5 E-072$ & 2.9E-06 & $1.0 \mathrm{E}-073$ & $3.2 E-06$ & 6 & 2.1E-07 & $5.5 E-07$ & 769 \\
\hline $\mathrm{CHZ}$ & 0.240 & 0.049 & 293 & 1.57 & 0.10 & 0.331 & 0.039 & 2.35 & 0.05 & 293 & 0.320 & 0.041 & 0.97 & 0.07 & 293 & 0.5 & 1.8 & 206 & $4.5 \mathrm{E}-116$ & $6.5 E-10$ & 3.2E-11 & $9.9 E-08$ & 69 & 1.1E-10 & $1.3 E-10$ & 0293 \\
\hline$B T$ & 0.169 & 0.050 & 69 & 1.79 & 0.13 & 0.266 & 0.041 & 2.44 & 0.08 & 69 & 0.265 & 0.040 & 1.00 & 0.03 & 69 & 0.2 & 2.3 & 59 & $8.4 \mathrm{E}-118$ & $8.5 E-12$ & 7.4E-11 & 1. $0 \mathrm{E}-07$ & 3 & $1.4 \mathrm{E}-11$ & 2.1E-11 & 169 \\
\hline PP4 & 0.236 & 0.055 & 47 & 1.62 & 0.09 & 0.325 & 0.045 & 2.41 & 0.04 & 47 & 0.308 & 0.051 & 0.94 & 0.08 & 47 & 0.3 & 10.9 & 43 & $7.5 E-113$ & 3. $4 \mathrm{E}-11$ & 5.9E-11 & $1.0 E-07$ & 5 & $9.6 \mathrm{E}-11$ & $1.4 E-10$ & $\begin{array}{ll}0 & 47\end{array}$ \\
\hline PP3 & 0.274 & 0.053 & 166 & 1.79 & 0.12 & 0.303 & 0.043 & 2.58 & 0.05 & 166 & 0.165 & 0.092 & 0.55 & 0.29 & 166 & 0.6 & 0.8 & 141 & $1.9 \mathrm{E}-082$ & $2.9 E-08$ & $3.2 \mathrm{E}-09$ & 7.0E-08 & 29 & $2.9 E-10$ & $4.0 \mathrm{E}-10$ & 0166 \\
\hline PP2 & 0.217 & 0.060 & 140 & 1.85 & 0.21 & 0.263 & 0.072 & 2.51 & 0.06 & 140 & 0.248 & 0.081 & 0.93 & 0.10 & 140 & 0.4 & 1.7 & 124 & 2.8E-10 1 & $1.2 E-09$ & 1.4E-10 & 9.9E-08 & 25 & $5.6 \mathrm{E}-11$ & 1. $1 \mathrm{E}-10$ & 0140 \\
\hline PP1 & 0.197 & 0.055 & 245 & 1.74 & 0.15 & 0.280 & 0.053 & 2.42 & 0.07 & 245 & 0.269 & 0.051 & 0.96 & 0.08 & 245 & 0.6 & 5.5 & 226 & $9.4 \mathrm{E}-111$ & 1. $6 \mathrm{E}-10$ & $5.5 \mathrm{E}-11$ & $1.0 E-07$ & 21 & 3. $1 \mathrm{E}-11$ & $5.6 \mathrm{E}-11$ & 1245 \\
\hline$B F 3$ & 0.102 & 0.038 & 86 & 2.28 & 0.09 & 0.115 & 0.040 & 2.57 & 0.03 & 86 & 0.112 & 0.039 & 0.98 & 0.07 & 86 & 0.6 & 4.5 & 86 & 8.7E-11 & - & 8.7E-11 & - & 1 & 2.1E-12 & $2.4 \mathrm{E}-12$ & 286 \\
\hline BF2 & 0.213 & 0.083 & 65 & 1.79 & 0.21 & 0.259 & 0.084 & 2.41 & 0.05 & 65 & 0.261 & 0.089 & 1.00 & 0.08 & 65 & 0.1 & 3.4 & 61 & $8.8 E-105$ & $5.4 \mathrm{E}-10$ & $5.3 E-10$ & $9.8 \mathrm{E}-08$ & 2 & $5.0 E-11$ & 7. OE-10 & 065 \\
\hline
\end{tabular}


Table 8. Moisture-retention $v$ an Genuchten curve-fit parameters, alpha and $n$, for each hy drogeologic unit.

[SE, standard error; $v / v$, dimensionless volume; undef., undef ined $v$ alues of less than or equal to zero on a log scale; $N$, number of data sets; $m, 1-(1 / n) ;$ paramet $\epsilon$ unit $C C R$ are from unit TC; parameters for units $B T 1$ and $C H V$ are from unit BT2]

\begin{tabular}{|c|c|c|c|c|c|c|c|c|c|c|c|c|c|c|c|c|c|c|c|c|}
\hline \multirow[b]{2}{*}{$\begin{array}{l}\text { Hydro- } \\
\text { geologic } \\
\text { Unit }\end{array}$} & \multirow{2}{*}{\multicolumn{2}{|c|}{$\begin{array}{c}\text { alpha } \\
N(1 / \text { bars })\end{array}$}} & \multicolumn{8}{|c|}{ Laboratory Desorption Curves van Genuchten parameters } & \multicolumn{10}{|c|}{ Composite Curves van Genuchten parameters } \\
\hline & & & SE & $\begin{array}{r}\begin{array}{r}95-p e \\
\text { confiden }\end{array} \\
\text { upper }\end{array}$ & $\begin{array}{l}\text { ercent } \\
\frac{\text { ice limits }}{\text { lower }}\end{array}$ & $\mathbf{n}$ & SE & $\begin{array}{r}\begin{array}{r}95-p e r \\
\text { confidenc }\end{array} \\
\text { upper }\end{array}$ & $\begin{array}{l}\text { rcent } \\
\text { ce limits } \\
\text { lower }\end{array}$ & $\mathrm{m}$ & $\begin{array}{c}\text { alpha } \\
\text { (1/bars) }\end{array}$ & SE & $\begin{array}{r}\text { 95-perc } \\
\text { confidence } \\
\text { upper }\end{array}$ & $\begin{array}{l}\text { cent } \\
\text { e limits } \\
\text { lower }\end{array}$ & $\mathbf{n}$ & SE & $\begin{array}{r}\begin{array}{r}95-p e r \\
\text { confidenc }\end{array} \\
\text { upper }\end{array}$ & $\begin{array}{l}\text { rcent } \\
\frac{\text { ee limits }}{\text { lower }}\end{array}$ & m & $\begin{array}{l}\text { Residual } \\
\text { Saturation } \\
\text { (v/v) }\end{array}$ \\
\hline CCR & & 0.335 & 0.140 & & & 1.254 & 0.037 & & & 0.203 & & & & & & & & & & 0.20 \\
\hline CUC & 3 & 0.827 & 0.227 & 1.290 & 0.364 & 1.840 & 0.221 & 2.291 & 1.388 & 0.457 & & & & & & & & & & 0.04 \\
\hline CUL & 3 & 1.404 & 0.462 & 2.344 & 0.463 & 1.529 & 0.110 & 1.752 & 1.306 & 0.346 & & & & & & & & & & 0.06 \\
\hline$C W$ & 7 & 0.115 & 0.029 & 0.173 & 0.056 & 1.300 & 0.041 & 1.383 & 1.219 & 0.231 & 0.124 & 0.024 & 0.176 & 0.072 & 1.690 & 0.171 & 2.068 & 1.321 & 0.408 & 0.13 \\
\hline$C M W$ & 2 & 0.023 & 0.008 & 0.039 & 0.007 & 1.776 & 0.309 & 2.417 & 1.135 & 0.437 & 0.028 & 0.011 & 0.054 & 0.002 & 1.890 & 0.337 & 2.692 & 1.098 & 0.471 & 0.33 \\
\hline CNW & 4 & 7.522 & 6.465 & 20.610 & undef. & 1.203 & 0.047 & 1.299 & 1.107 & 0.169 & 2.420 & 1.647 & 6.197 & undef. & 1.380 & 0.124 & 1.666 & 1.095 & 0.275 & 0.10 \\
\hline BT4 & 5 & 3.652 & 1.930 & 7.516 & undef. & 1.285 & 0.052 & 1.389 & 1.181 & 0.222 & 17.889 & 11.110 & 43.509 & undef. & 1.233 & 0.049 & 1.346 & 1.120 & 0.189 & 0.10 \\
\hline TPY & 2 & 0.756 & 0.296 & 1.380 & 0.131 & 1.953 & 0.377 & 2.747 & 1.158 & 0.488 & 2.638 & 1.812 & 7.296 & undef. & 1.507 & 0.171 & 1.947 & 1.067 & 0.336 & 0.14 \\
\hline BT3 & 3 & 2.590 & 1.500 & 5.659 & undef. & 1.310 & 0.067 & 1.443 & 1.168 & 0.237 & 41.540 & 19.147 & 85.691 & undef. & 1.234 & 0.044 & 1.336 & 1.133 & 0.190 & 0.17 \\
\hline TPP & 1 & 3.412 & 2.145 & 8.265 & undef. & 1.427 & 0.129 & 1.719 & 1.136 & 0.299 & 40.016 & 15.204 & 77.217 & 2.815 & 1.494 & 0.140 & 1.837 & 1.151 & 0.331 & 0.10 \\
\hline$B T 2$ & 2 & 9.800 & 8.695 & 27.939 & undef. & 1.294 & 0.072 & 1.445 & 1.144 & 0.227 & 52.638 & 41.468 & 148.261 & undef. & 1.278 & 0.076 & 1.454 & 1.103 & 0.218 & 0.10 \\
\hline$T C$ & 2 & 0.335 & 0.140 & 0.632 & 0.039 & 1.254 & 0.037 & 1.332 & 1.175 & 0.203 & 0.885 & 0.418 & 1.907 & undef. & 1.249 & 0.043 & 1.354 & 1.145 & 0.199 & 0.11 \\
\hline$T R$ & 3 & 2.037 & 0.754 & 3.576 & 0.499 & 1.335 & 0.051 & 1.439 & 1.231 & 0.251 & 3.776 & 2.399 & $9.151 \mathrm{u}$ & undef . & 1.317 & 0.106 & 1.553 & 1.081 & 0.241 & 0.04 \\
\hline TUL & 4 & 0.657 & 0.150 & 0.958 & 0.355 & 1.331 & 0.032 & 1.396 & 1.267 & 0.249 & & & & & & & & & & 0.06 \\
\hline TMN & 3 & 0.064 & 0.013 & 0.091 & 0.038 & 1.470 & 0.076 & 1.624 & 1.316 & 0.320 & & & & & & & & & & 0.18 \\
\hline$T L L$ & 3 & 0.273 & 0.105 & 0.485 & 0.060 & 1.294 & 0.051 & 1.398 & 1.189 & 0.227 & & & & & & & & & & 0.08 \\
\hline TMR & 1 & 0.047 & 0.005 & 0.060 & 0.034 & 1.713 & 0.078 & 1.897 & 1.530 & 0.416 & & & & & & & & & & 0.18 \\
\hline$T M$ & 1 & 0.022 & 0.002 & 0.026 & 0.017 & 2.141 & 0.267 & 2.727 & 1.554 & 0.533 & & & & & & & & & & 0.32 \\
\hline PV3 & 3 & 0.010 & 0.003 & 0.016 & 0.004 & 1.582 & 0.127 & 1.845 & 1.319 & 0.368 & & & & & & & & & & 0.50 \\
\hline PV2 & 1 & 1.255 & 0.652 & 2.797 & undef. & 1.310 & 0.075 & 1.488 & 1.133 & 0.237 & & & & & & & & & & 0.12 \\
\hline BT1a & 3 & 0.019 & 0.008 & 0.035 & 0.003 & 1.561 & 0.180 & 1.931 & 1.191 & 0.359 & & & & & & & & & & 0.36 \\
\hline BT1 & & 9.800 & 8.695 & 27.939 & undef. & 1.294 & 0.072 & 1.445 & 1.144 & 0.227 & & & & & & & & & & 0.04 \\
\hline $\mathrm{CHV}$ & & 9.800 & 8.695 & 27.939 & undef. & 1.294 & 0.072 & 1.445 & 1.144 & 0.227 & & & & & & & & & & 0.06 \\
\hline $\mathrm{CHZ}$ & 4 & 0.394 & 0.125 & 0.647 & 0.142 & 1.290 & 0.037 & 1.365 & 1.215 & 0.225 & & & & & & & & & & 0.20 \\
\hline$B T$ & 1 & 0.015 & 0.001 & 0.018 & 0.012 & 1.909 & 0.111 & 2.151 & 1.667 & 0.476 & & & & & & & & & & 0.33 \\
\hline PP4 & 1 & 0.010 & 0.001 & 0.009 & 0.007 & 3.035 & 0.404 & 3.967 & 2.104 & 0.671 & & & & & & & & & & 0.25 \\
\hline$P P 3$ & 3 & 1.817 & 0.599 & 3.032 & 0.601 & 1.455 & 0.071 & 1.599 & 1.311 & 0.313 & & & & & & & & & & 0.07 \\
\hline$P P 2$ & 3 & 0.072 & 0.012 & 0.097 & 0.046 & 1.603 & 0.081 & 1.768 & 1.439 & 0.376 & & & & & & & & & & 0.10 \\
\hline$P P 1$ & 2 & 0.179 & 0.060 & 0.305 & 0.054 & 1.454 & 0.078 & 1.616 & 1.292 & 0.312 & & & & & & & & & & 0.18 \\
\hline$B F 3$ & 1 & 0.036 & 0.010 & 0.063 & 0.009 & 1.680 & 0.202 & 2.240 & 1.119 & 0.405 & & & & & & & & & & 0.09 \\
\hline$B F 2$ & 1 & 0.012 & 0.001 & 0.014 & 0.010 & 2.477 & 0.275 & 3.353 & 1.602 & 0.596 & & & & & & & & & & 0.19 \\
\hline
\end{tabular}


ity was estimated using the regression equation for the matrix only and is 3 orders of magnitude lower for TC and 2 orders of magnitude lower for PV3. There are also mismatches in the units below the Topopah Spring Tuff, which have variable degrees of alteration and crystallization and were all estimated using the equation for the altered rocks.

Moisture-retention curve-fit parameters have been calculated for all the hydrogeologic units with corresponding standard error and 95-percent confidence limits as are the parameters for composite curves (table 8). Units CUC and CUL, although penetrated by boreholes, did not have samples that were measured for field water potential, so no composite curves were obtained for those units and parameters are from laboratory measurements only. The number of data sets, $\mathrm{N}$, on which laboratory measurements for moisture retention were made is noted for each unit. Several of the units, CCR, TPP, BT2, TC, and CHV, posed measurement challenges as samples disintegrated due to frequent sample handling and, therefore, are represented by only a few samples. It is not believed that the parameters for units TPP, BT2, or TC were unrepresentative or were compromised due to the low number of samples. Parameters for CCR are represented by hydrogeologic unit $\mathrm{TC}$, and this approximation is supported by the general similarities in lithostratigraphic features and context of the units (D.C. Buesch and R.W. Spengler, U.S. Geological Survey, written commun., 1996). Data obtained for CHV could only be obtained on coherent samples and was very biased toward unrepresentative lower porosity inclusions. Parameters from these samples, therefore, did not represent the saturations measured in boreholes SD7 and SD12. The saturation profiles were better represented by the parameters calculated for unit BT2 that had the highest $\alpha$ of all units. Both the CHV and BT2 are vitric, are high in porosity and conductivity, and have slight and variable alteration. No moisture-retention data were available for the unaltered BT1, and this unit is also represented by the BT2 parameters. Residual saturation values used in the curve-fitting process are included in table 8.

\section{Spatial Distribution of Porosity}

Representation of hydrologic properties of a spatially heterogeneous site, based on core-scale-sized samples from one-dimensional boreholes sparsely dis- tributed over the study area has uncertainty. Vertical variability of matrix properties within hydrogeologic units can be reasonably described for most of the units. Problematic units are very thin or layered units or are those with features that are larger than core-size samples that might dominate the flow of water in numerical models. The lateral distribution of core-scale properties might adequately be represented for large-scale models by the correlation of properties with surrogates, such as porosity, that can be modeled using lithostratigraphic distributions and that has been shown to be related to flow properties in this report and others (Istok and others, 1994; Rautman and others, 1995; Flint and others, 1996b; Rautman, 1995). The correlation of porosity with lithology provides a much larger data base with which to calculate spatial distributions.

Few of the hydrogeologic units described in this report were penetrated by enough boreholes that spatial trends in porosity, if present, could be visualized. A data set was compiled for all boreholes sampled that includes means and standard deviations for porosity and saturation for all hydrogeologic units (table 9). Table 9 helps illustrate two important limitations of these data for representing the spatial variability of properties such as porosity. Of the 30 hydrogeologic units, there are 17 units that occur in 6 or fewer boreholes. These units are typically above $\mathrm{CW}$ and below TLL. Of the 203 entries in table 9, where each entry represents at least 1 sample of a unit in a borehole, 57 units have 5 or fewer samples per unit, and a total of 107 units have 10 or fewer samples per unit. With about 53 percent of all available means calculated on 10 or fewer samples per unit, the statistical significance of these data must be kept in perspective. Many of the units were extremely variable; for example, the thin, infrequently sampled hydrogeologic unit, BT4, ranges from a mean porosity of 26 percent in N31 to 62 percent in SD9. The thicker and more frequently sampled unit, TPP, on the other hand, only ranges from 47 percent to 52 percent porosity. Porosity ranges from 7 percent to 12 percent for unit $\mathrm{CW}$, with a general trend of increasing porosity to the northwest (fig. 16). This trend is consistent with descriptions of lithostratigraphic units exposed at the surface (Scott and Bonk, 1984; W. C. Day, U.S. Geological Survey, written commun., 1996) and in core from boreholes (Buesch and others, 1996b). More spatially variable is hydrogeologic unit BT2 (fig. 16), with a range of 44 percent to 53 percent porosity, except for one low value of 35 percent in the south in SD7. Rocks in the PTn are likely 

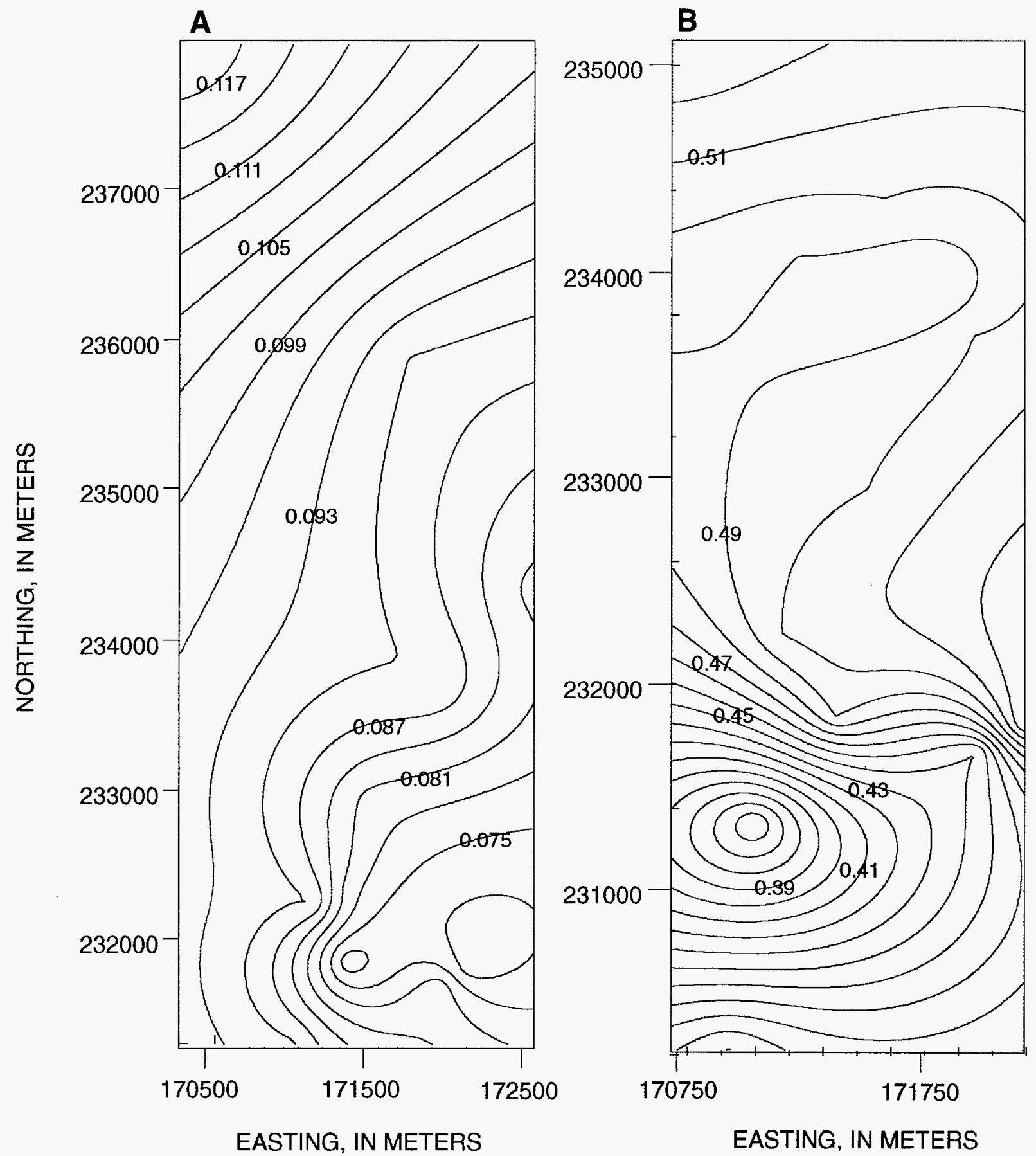

Figure 16. Contour plots of the spatial distribution of porosity for hydrogeologic units (a) CW, using 17 boreholes, and (b) BT2, using 15 boreholes. 
Table 9. Mean porosity and saturation, and standard deviations for each hydrogeologic unit in for each borehole

[Por, porosity, SD, standard deviation; Sat, saturation; $N$, number of samples]

\begin{tabular}{|c|c|c|c|c|c|c|c|c|c|c|c|c|c|c|c|c|}
\hline Unit & & NRG-6 & NRG-7 & SD-12 & SD-7 & SD-9 & UZ 14 & UZ 16 & UZ 27a & $\mathrm{N}-11$ & $\mathrm{~N}-15$ & $\mathrm{~N}-16$ & $\mathrm{~N}-17$ & $\mathrm{~N}-27$ & $\mathrm{~N}-31$ & $\mathrm{~N}-32$ \\
\hline \multirow[t]{5}{*}{$\overline{\mathrm{CCR}}$} & Mean por & & & & & & & & & & 0.05 & & 0.08 & & & \\
\hline & SD Por & & & & & & & & & & 0.00 & & 0.01 & & & \\
\hline & Mean Sat & & & & & & & & & & 0.87 & & 0.64 & & & \\
\hline & SD Sat & & & & & & & & & & 0.00 & & 0.02 & & & \\
\hline & $\mathrm{N}$ & & & & & & & & & & 1 & & 2 & & & \\
\hline \multirow[t]{5}{*}{ CUC } & Mean Por & & & & & & & & & & 0.24 & & 0.25 & 0.26 & & \\
\hline & SD Por & & & & & & & & & & 0.06 & & 0.05 & 0.06 & & \\
\hline & Mean Sat & & & & & & & & & & 0.51 & & 0.52 & 0.24 & & \\
\hline & SD Sat & & & & & & & & & & 0.12 & & 0.11 & 0.08 & & \\
\hline & $\mathrm{N}$ & & & & & & & & & & 22 & & 26 & 24 & & \\
\hline \multirow[t]{5}{*}{ CUL } & Mean Por & & & & & & & & & & & 0.13 & & 0.14 & & \\
\hline & SD Por & & & & & & & & & & & 0.04 & & 0.02 & & \\
\hline & Mean Sat & & & & & & & & & & & 0.59 & & 0.62 & & \\
\hline & SD Sat & & & & & & & & & & & 0.11 & & 0.11 & & \\
\hline & $\mathrm{N}$ & & & & & & & & & & & & & 43 & & \\
\hline \multirow[t]{5}{*}{$\mathrm{CW}$} & Mean Por & 0.09 & 0.09 & 0.09 & 0.09 & & & 0.07 & 0.07 & 0.12 & & & & 0.10 & 0.08 & 0.07 \\
\hline & SD Por & 0.03 & 0.02 & 0.03 & 0.02 & & & 0.02 & 0.02 & 0.00 & & & & 0.01 & 0.02 & 0.02 \\
\hline & Mean Sat & & & 0.75 & 0.85 & & & 0.79 & 0.77 & 0.96 & & & & 0.66 & 0.87 & 0.82 \\
\hline & SD Sat & & & 0.15 & 0.10 & & & 0.17 & 0.12 & 0.04 & & & & 0.12 & 0.03 & 0.07 \\
\hline & $\mathrm{N}$ & 38 & 16 & 64 & 80 & & & 34 & 40 & 2 & & & & 7 & 24 & 32 \\
\hline \multirow[t]{5}{*}{ CMW } & Mean Por & 0.18 & 0.18 & 0.17 & 0.20 & & & 0.30 & 0.27 & 0.21 & & & & & 0.20 & 0.18 \\
\hline & SD Por & 0.03 & 0.02 & 0.01 & 0.03 & & & 0.08 & 0.10 & 0.03 & & & & & 0.03 & 0.02 \\
\hline & Mean Sat & & & 0.88 & 0.97 & & & 0.96 & 0.91 & 0.71 & & & & & 0.96 & 0.90 \\
\hline & SD Sat & & & 0.07 & 0.03 & & & 0.05 & 0.10 & 0.26 & & & & & 0.03 & 0.10 \\
\hline & $\mathrm{N}$ & 10 & 6 & 3 & 4 & & & 6 & 4 & 2 & & & & & 8 & 6 \\
\hline \multirow[t]{5}{*}{ CNW } & Mean Por & 0.39 & 0.36 & 0.34 & 0.43 & 0.36 & & 0.42 & 0.37 & 0.47 & & & & & 0.38 & 0.36 \\
\hline & SD Por & 0.03 & 0.03 & 0.03 & 0.00 & 0.04 & & 0.00 & 0.07 & 0.09 & & & & & 0.06 & 0.05 \\
\hline & Mean Sat & & & 0.78 & 0.39 & 0.68 & & 0.59 & 0.78 & 0.44 & & & & & 0.99 & 0.88 \\
\hline & SD Sat & & & 0.18 & 0.02 & 0.17 & & 0.09 & 0.18 & 0.24 & & & & & 0.01 & 0.07 \\
\hline & $\mathrm{N}$ & 4 & 9 & 5 & 2 & 6 & & 2 & 8 & 10 & & & & & 6 & 5 \\
\hline \multirow[t]{5}{*}{ BT4 } & Mean Por & 0.38 & 0.41 & 0.61 & 0.56 & 0.62 & & 0.52 & 0.35 & 0.51 & & & & & 0.26 & 0.55 \\
\hline & SD Por & 0.00 & 0.08 & 0.00 & 0.00 & 0.00 & & 0.00 & 0.01 & 0.07 & & & & & 0.11 & 0.12 \\
\hline & Mean Sat & & & 0.64 & 0.53 & 0.60 & & 0.62 & 0.57 & 0.34 & & & & & 0.77 & 0.71 \\
\hline & SD Sat & & & 0.00 & 0.00 & 0.00 & & 0.00 & 0.02 & 0.07 & & & & & 0.12 & 0.05 \\
\hline & $\mathrm{N}$ & 1 & 5 & 1 & 1 & 1 & & 1 & 2 & 6 & & & & & 4 & 2 \\
\hline \multirow[t]{5}{*}{ TPY } & Mean Por & & 0.29 & & & & 0.18 & & & 0.23 & & & & & & \\
\hline & SD Por & & 0.01 & & & & 0.02 & & & 0.03 & & & & & & \\
\hline & Mean Sat & & & & & & 0.94 & & & 0.54 & & & & & & \\
\hline & SD Sat & & & & & & 0.08 & & & 0.18 & & & & & & \\
\hline & $\mathrm{N}$ & & 3 & & & & 7 & & & 6 & & & & & & \\
\hline \multirow[t]{5}{*}{ BT3 } & Mean por & 0.40 & 0.36 & 0.42 & 0.34 & 0.36 & 0.41 & 0.44 & 0.39 & & & & & & 0.42 & 0.51 \\
\hline & SD Por & 0.02 & 0.08 & 0.06 & 0.02 & 0.06 & 0.07 & 0.08 & 0.03 & & & & & & 0.12 & 0.06 \\
\hline & Mean Sat & & & 0.55 & 0.57 & 0.53 & 0.77 & 0.41 & 0.68 & & & & & & 0.55 & 0.59 \\
\hline & SD Sat & & & 0.07 & 0.07 & 0.13 & 0.20 & 0.09 & 0.03 & & & & & & 0.08 & 0.09 \\
\hline & $\mathrm{N}$ & 5 & 10 & 3 & 3 & 16 & 11 & 7 & 3 & & & & & & 4 & 5 \\
\hline \multirow[t]{5}{*}{ TPP } & Mean por & 0.51 & 0.49 & 0.47 & & 0.47 & 0.49 & & 0.48 & & & & & & 0.50 & 0.50 \\
\hline & SD Por & 0.03 & 0.03 & 0.02 & & 0.03 & 0.04 & & 0.00 & & & & & & 0.04 & 0.03 \\
\hline & Mean Sat & & & 0.50 & & 0.33 & 0.50 & & 0.54 & & & & & & 0.49 & 0.44 \\
\hline & SD Sat & & & 0.05 & & 0.04 & 0.06 & & 0.00 & & & & & & 0.09 & 0.08 \\
\hline & $\mathrm{N}$ & 22 & 27 & 4 & & 13 & 46 & & 1 & & & & & & 9 & 10 \\
\hline \multirow[t]{5}{*}{ BT2 } & Mean por & 0.50 & 0.50 & 0.50 & 0.35 & 0.49 & 0.53 & 0.53 & 0.49 & & & & & & 0.50 & 0.53 \\
\hline & SD Por & 0.10 & 0.04 & 0.09 & 0.09 & 0.07 & 0.05 & 0.10 & 0.05 & & & & & & 0.08 & 0.07 \\
\hline & Mean Sat & & & 0.47 & 0.52 & 0.35 & 0.33 & 0.29 & 0.41 & & & & & & 0.51 & 0.51 \\
\hline & SD Sat & & & 0.14 & 0.14 & 0.12 & 0.05 & 0.08 & 0.13 & & & & & & 0.11 & 0.12 \\
\hline & $\mathrm{N}$ & 22 & 9 & 9 & 4 & 11 & 8 & 13 & 8 & & & & & & 16 & 16 \\
\hline
\end{tabular}


Table 9. Mean porosity and saturation, and standard deviations for each hydrogeologic unit in for each borehole

[Por, porosity, SD, standard deviation; Sat, saturation; N, number of samples]

\begin{tabular}{|c|c|c|c|c|c|c|c|c|c|c|c|c|c|c|c|c|c|}
\hline \multirow{2}{*}{$\frac{\text { Unit }}{\text { CCR }}$} & & $\mathrm{N}-33$ & $\mathrm{~N}-34$ & $\mathrm{~N}-35$ & $\mathrm{~N}-36$ & $\mathrm{~N}-37$ & $\mathrm{~N}-38$ & $\mathrm{~N}-53$ & N-54 & N-55 & $\mathrm{N}-57$ & $\mathrm{~N}-58$ & $\mathrm{~N}-59$ & N-61 & $N-62$ & $\mathrm{~N}-63$ & $\mathrm{~N}-64$ \\
\hline & $\begin{array}{l}\text { Mean por } \\
\text { SD Por } \\
\text { Mean Sat } \\
\text { SD Sat } \\
\text { N }\end{array}$ & & & & $\begin{array}{l}0.06 \\
0.02 \\
0.76 \\
0.14 \\
6\end{array}$ & & & & & & & & & & & & \\
\hline CUC & $\begin{array}{l}\text { Mean Por } \\
\text { SD Por } \\
\text { Mean Sat } \\
\text { SD Sat } \\
\text { N }\end{array}$ & & & & $\begin{array}{l}0.18 \\
0.00 \\
0.47 \\
0.00 \\
1\end{array}$ & & & & & & & & & & $\begin{array}{l}0.24 \\
0.01 \\
0.32 \\
0.04 \\
5\end{array}$ & & $\begin{array}{l}0.24 \\
0.03 \\
0.26 \\
0.15 \\
12\end{array}$ \\
\hline CUL & $\begin{array}{l}\text { Mean Por } \\
\text { SD Por } \\
\text { Mean Sat } \\
\text { SD Sat } \\
\text { N }\end{array}$ & & & & $\begin{array}{l}0.29 \\
0.05 \\
0.45 \\
0.08 \\
15\end{array}$ & & & & & & & & & & $\begin{array}{l}0.13 \\
0.03 \\
0.73 \\
0.16 \\
20\end{array}$ & & $\begin{array}{c}0.16 \\
0.02 \\
0.62 \\
0.16 \\
11\end{array}$ \\
\hline CW & $\begin{array}{l}\text { Mean Por } \\
\text { SD Por } \\
\text { Mean Sat } \\
\text { SD Sat } \\
\text { N }\end{array}$ & & & $\begin{array}{l}0.08 \\
0.03 \\
0.81 \\
0.12 \\
38\end{array}$ & $\begin{array}{l}0.09 \\
0.04 \\
0.85 \\
0.11 \\
21\end{array}$ & & $\begin{array}{c}0.09 \\
0.02 \\
0.88 \\
0.05 \\
17\end{array}$ & $\begin{array}{r}0.08 \\
0.06 \\
0.85 \\
0.06 \\
54\end{array}$ & $\begin{array}{l}0.07 \\
0.02 \\
0.82 \\
0.09 \\
43\end{array}$ & $\begin{array}{c}0.08 \\
0.02 \\
0.80 \\
0.13 \\
67\end{array}$ & & & & & & $\begin{array}{l}0.08 \\
0.03 \\
0.82 \\
0.13 \\
22\end{array}$ & \\
\hline CMW & $\begin{array}{l}\text { Mean Por } \\
\text { SD Por } \\
\text { Mean Sat } \\
\text { SD Sat } \\
\text { N }\end{array}$ & $\begin{array}{l}0.19 \\
0.06 \\
0.97 \\
0.01 \\
6\end{array}$ & & & & $\begin{array}{l}0.20 \\
0.03 \\
0.84 \\
0.13 \\
8\end{array}$ & $\begin{array}{c}0.20 \\
0.04 \\
1.02 \\
0.13 \\
11\end{array}$ & $\begin{array}{l}0.26 \\
0.05 \\
0.92 \\
0.13 \\
5\end{array}$ & $\begin{array}{l}0.19 \\
0.02 \\
0.82 \\
0.05 \\
3\end{array}$ & $\begin{array}{l}0.20 \\
0.04 \\
0.94 \\
0.05 \\
11\end{array}$ & & & & & & & \\
\hline $\mathrm{CNW}$ & $\begin{array}{l}\text { Mean Por } \\
\text { SD Por } \\
\text { Mean Sat } \\
\text { SD Sat } \\
\text { N }\end{array}$ & $\begin{array}{l}0.41 \\
0.07 \\
0.75 \\
0.14 \\
8\end{array}$ & & & & $\begin{array}{l}0.45 \\
0.04 \\
0.65 \\
0.25 \\
8\end{array}$ & & $\begin{array}{l}0.41 \\
0.03 \\
0.69 \\
0.19 \\
7\end{array}$ & $\begin{array}{c}0.37 \\
0.05 \\
0.71 \\
0.24 \\
11\end{array}$ & $\begin{array}{l}0.34 \\
0.04 \\
0.67 \\
0.18 \\
6\end{array}$ & & & & & & & \\
\hline BT4 & $\begin{array}{l}\text { Mean Por } \\
\text { SD Por } \\
\text { Mean Sat } \\
\text { SD Sat } \\
\text { N }\end{array}$ & $\begin{array}{l}0.42 \\
0.08 \\
0.61 \\
0.16 \\
7\end{array}$ & $\begin{array}{l}0.39 \\
0.07 \\
0.70 \\
0.06 \\
3\end{array}$ & & & $\begin{array}{l}0.46 \\
0.08 \\
0.42 \\
0.00 \\
2\end{array}$ & & & & & & & & & & & \\
\hline TPY & $\begin{array}{l}\text { Mean Por } \\
\text { SD Por } \\
\text { Mean Sat } \\
\text { SD Sat } \\
\text { N }\end{array}$ & $\begin{array}{l}0.22 \\
0.07 \\
0.65 \\
0.16 \\
6\end{array}$ & $\begin{array}{r}0.23 \\
0.05 \\
0.76 \\
0.16 \\
11\end{array}$ & & & & & & & & & & & & & & \\
\hline BT3 & $\begin{array}{l}\text { Mean por } \\
\text { SD Por } \\
\text { Mean Sat } \\
\text { SD Sat } \\
\text { N }\end{array}$ & & & & & & & $\begin{array}{l}0.39 \\
0.10 \\
0.54 \\
0.13 \\
9\end{array}$ & $\begin{array}{l}0.46 \\
0.04 \\
0.50 \\
0.06 \\
9\end{array}$ & $\begin{array}{l}0.42 \\
0.05 \\
0.41 \\
0.09 \\
7\end{array}$ & & & & & & & \\
\hline TPP & $\begin{array}{l}\text { Mean por } \\
\text { SD Por } \\
\text { Mean Sat } \\
\text { SD Sat } \\
\text { N }\end{array}$ & & & & & $\begin{array}{l}0.52 \\
0.04 \\
0.27 \\
0.07 \\
32\end{array}$ & & & & & & & & & & & \\
\hline BT2 & $\begin{array}{l}\text { Mean por } \\
\text { SD Por } \\
\text { Mean Sat } \\
\text { SD Sat } \\
\text { N }\end{array}$ & & & & & $\begin{array}{c}0.48 \\
0.09 \\
0.38 \\
0.12 \\
12\end{array}$ & & $\begin{array}{c}0.44 \\
0.14 \\
0.38 \\
0.15 \\
16\end{array}$ & $\begin{array}{c}0.50 \\
0.09 \\
0.44 \\
0.15 \\
15\end{array}$ & $\begin{array}{l}0.46 \\
0.07 \\
0.46 \\
0.08 \\
9\end{array}$ & & & & $\begin{array}{l}0.49 \\
0.01 \\
0.34 \\
0.02 \\
2\end{array}$ & & & \\
\hline
\end{tabular}


Table 9. Mean porosity and saturation, and standard deviations for each hydrogeologic unit in for each borehole--Continued

[Por, porosity, SD, standard deviation; Sat, saturation; N, number of samples]

\begin{tabular}{|c|c|c|c|c|c|c|c|c|c|c|c|c|c|c|c|c|}
\hline Unit & & NRG-6 & NRG-7 & SD-12 & SD-7 & SD-9 & $\mathrm{UZ} 14$ & UZ 16 & UZ 27a & $\mathrm{N}-11$ & $\mathrm{~N}-15$ & $\mathrm{~N}-16$ & $\mathrm{~N}-17$ & $\mathrm{~N}-27$ & $\mathrm{~N}-31$ & $\mathrm{~N}-32$ \\
\hline $\mathrm{TC}$ & $\begin{array}{l}\text { Mean por } \\
\text { SD Por } \\
\text { Mean Sat } \\
\text { SD Sat } \\
\text { N }\end{array}$ & $\begin{array}{l}0.04 \\
0.02\end{array}$ & $\begin{array}{l}0.06 \\
0.02\end{array}$ & $\begin{array}{l}0.03 \\
0.00 \\
0.74 \\
0.00 \\
1\end{array}$ & & $\begin{array}{l}0.05 \\
0.02 \\
0.74 \\
0.08 \\
7\end{array}$ & $\begin{array}{l}0.03 \\
0.01 \\
0.65 \\
0.16 \\
9\end{array}$ & $\begin{array}{l}0.04 \\
0.01 \\
0.80 \\
0.19 \\
3\end{array}$ & $\begin{array}{l}0.07 \\
0.02 \\
0.60 \\
0.18 \\
2\end{array}$ & & & & & & $\begin{array}{l}0.04 \\
0.01 \\
0.78 \\
0.22 \\
2\end{array}$ & $\begin{array}{l}0.05 \\
0.02 \\
0.64 \\
0.23 \\
4\end{array}$ \\
\hline TR & $\begin{array}{l}\text { Mean por } \\
\text { SD Por } \\
\text { Mean Sat } \\
\text { SD Sat } \\
\text { N }\end{array}$ & $\begin{array}{l}0.15 \\
0.04\end{array}$ & $\begin{array}{l}0.15 \\
0.03\end{array}$ & $\begin{array}{c}0.16 \\
0.02 \\
0.49 \\
0.09 \\
31\end{array}$ & $\begin{array}{l}0.17 \\
0.03 \\
0.49 \\
0.06 \\
30\end{array}$ & $\begin{array}{r}0.14 \\
0.03 \\
0.65 \\
0.13 \\
34\end{array}$ & $\begin{array}{c}0.16 \\
0.04 \\
0.53 \\
0.16 \\
37\end{array}$ & $\begin{array}{l}0.16 \\
0.02 \\
0.45 \\
0.10 \\
29\end{array}$ & $\begin{array}{l}0.16 \\
0.02 \\
0.60 \\
0.14 \\
31\end{array}$ & & & & & & & \\
\hline TUL & $\begin{array}{l}\text { Mean por } \\
\text { SD Por } \\
\text { Mean Sat } \\
\text { SD Sat } \\
\text { N }\end{array}$ & $\begin{array}{l}0.17 \\
0.03\end{array}$ & $\begin{array}{l}0.16 \\
0.03\end{array}$ & $\begin{array}{c}0.15 \\
0.03 \\
0.75 \\
0.13 \\
49\end{array}$ & $\begin{array}{l}0.13 \\
0.03 \\
0.79 \\
0.11 \\
57\end{array}$ & $\begin{array}{r}0.16 \\
0.03 \\
0.80 \\
0.09 \\
61\end{array}$ & $\begin{array}{l}0.15 \\
0.03 \\
0.85 \\
0.08 \\
66\end{array}$ & $\begin{array}{l}0.14 \\
0.03 \\
0.70 \\
0.09 \\
40\end{array}$ & $\begin{array}{l}0.14 \\
0.04 \\
0.86 \\
0.08 \\
13\end{array}$ & & & & & & & \\
\hline TMN & $\begin{array}{l}\text { Mean por } \\
\text { SD Por } \\
\text { Mean Sat } \\
\text { SD Sat } \\
\text { N }\end{array}$ & $\begin{array}{l}0.10 \\
0.01\end{array}$ & $\begin{array}{l}0.12 \\
0.02\end{array}$ & $\begin{array}{c}0.10 \\
0.01 \\
0.86 \\
0.05 \\
37\end{array}$ & $\begin{array}{l}0.11 \\
0.02 \\
0.94 \\
0.03 \\
39\end{array}$ & $\begin{array}{c}0.12 \\
0.02 \\
0.92 \\
0.05 \\
27\end{array}$ & $\begin{array}{c}0.12 \\
0.03 \\
0.88 \\
0.08 \\
35\end{array}$ & $\begin{array}{c}0.10 \\
0.02 \\
0.90 \\
0.05 \\
37\end{array}$ & $\begin{array}{l}0.10 \\
0.02 \\
0.82 \\
0.09 \\
38\end{array}$ & & & & & & & \\
\hline TLL & $\begin{array}{l}\text { Mean por } \\
\text { SD Por } \\
\text { Mean Sat } \\
\text { SD Sat } \\
\text { N }\end{array}$ & $\begin{array}{l}0.14 \\
0.03\end{array}$ & $\begin{array}{l}0.13 \\
0.02\end{array}$ & $\begin{array}{c}0.12 \\
0.03 \\
0.87 \\
0.05 \\
40\end{array}$ & $\begin{array}{c}0.13 \\
0.03 \\
0.89 \\
0.05 \\
59\end{array}$ & $\begin{array}{l}0.13 \\
0.02 \\
0.85 \\
0.07 \\
72\end{array}$ & $\begin{array}{c}0.14 \\
0.03 \\
0.82 \\
0.09 \\
44\end{array}$ & $\begin{array}{c}0.14 \\
0.04 \\
0.78 \\
0.12 \\
61\end{array}$ & $\begin{array}{c}0.12 \\
0.02 \\
0.78 \\
0.08 \\
39\end{array}$ & & & & & & & \\
\hline TM2 & $\begin{array}{l}\text { Mean por } \\
\text { SD Por } \\
\text { Mean Sat } \\
\text { SD Sat } \\
\text { N }\end{array}$ & & $\begin{array}{l}0.11 \\
0.03\end{array}$ & $\begin{array}{l}0.10 \\
0.02 \\
0.82 \\
0.10 \\
40\end{array}$ & $\begin{array}{l}0.10 \\
0.04 \\
0.91 \\
0.04 \\
41\end{array}$ & $\begin{array}{c}0.11 \\
0.02 \\
0.88 \\
0.05 \\
31\end{array}$ & $\begin{array}{l}0.12 \\
0.03 \\
0.89 \\
0.07 \\
45\end{array}$ & $\begin{array}{l}0.11 \\
0.04 \\
0.88 \\
0.07 \\
41\end{array}$ & & & & & & & & \\
\hline TM1 & $\begin{array}{l}\text { Mean por } \\
\text { SD Por } \\
\text { Mean Sat } \\
\text { SD Sat } \\
\text { N }\end{array}$ & & $\begin{array}{l}0.10 \\
0.02\end{array}$ & $\begin{array}{l}0.08 \\
0.01 \\
0.89 \\
0.05 \\
20\end{array}$ & $\begin{array}{l}0.08 \\
0.01 \\
0.91 \\
0.03 \\
18\end{array}$ & $\begin{array}{c}0.10 \\
0.02 \\
0.92 \\
0.08 \\
13\end{array}$ & $\begin{array}{l}0.10 \\
0.02 \\
0.91 \\
0.07 \\
19\end{array}$ & $\begin{array}{l}0.10 \\
0.02 \\
0.85 \\
0.06 \\
17\end{array}$ & & & & & & & & \\
\hline PV3 & $\begin{array}{l}\text { Mean por } \\
\text { SD Por } \\
\text { Mean Sat } \\
\text { SD Sat } \\
\text { N }\end{array}$ & & $\begin{array}{l}0.02 \\
0.02\end{array}$ & $\begin{array}{l}0.07 \\
0.11 \\
0.89 \\
0.06 \\
7\end{array}$ & $\begin{array}{c}0.03 \\
0.01 \\
0.89 \\
0.07 \\
26\end{array}$ & $\begin{array}{l}0.02 \\
0.01 \\
0.85 \\
0.07 \\
18\end{array}$ & $\begin{array}{l}0.04 \\
0.02 \\
0.96 \\
0.12 \\
18\end{array}$ & $\begin{array}{c}0.06 \\
0.03 \\
0.92 \\
0.06 \\
11\end{array}$ & & & & & & & & \\
\hline PV2 & $\begin{array}{l}\text { Mean por } \\
\text { SD Por } \\
\text { Mean Sat } \\
\text { SD Sat } \\
\text { N }\end{array}$ & & $\begin{array}{l}0.07 \\
0.02\end{array}$ & $\begin{array}{l}0.15 \\
0.07 \\
0.66 \\
0.17 \\
10\end{array}$ & $\begin{array}{l}0.09 \\
0.03 \\
0.78 \\
0.09 \\
7\end{array}$ & $\begin{array}{l}0.18 \\
0.00 \\
0.70 \\
0.00 \\
1\end{array}$ & $\begin{array}{l}0.26 \\
0.12 \\
0.97 \\
0.02 \\
12\end{array}$ & $\begin{array}{l}0.21 \\
0.06 \\
0.93 \\
0.03 \\
5\end{array}$ & & & & & & & & \\
\hline BT 1 & $\begin{array}{l}\text { Mean por } \\
\text { SD Por } \\
\text { Mean Sat } \\
\text { SD Sat } \\
\text { N }\end{array}$ & & $\begin{array}{l}0.26 \\
0.04\end{array}$ & $\begin{array}{c}0.33 \\
0.03 \\
0.27 \\
0.06 \\
21\end{array}$ & $\begin{array}{r}0.22 \\
0.05 \\
0.36 \\
0.10 \\
22\end{array}$ & $\begin{array}{c}0.29 \\
0.09 \\
0.84 \\
0.16 \\
18\end{array}$ & $\begin{array}{r}0.31 \\
0.04 \\
1.07 \\
0.08 \\
11\end{array}$ & & & & & & & & & \\
\hline
\end{tabular}


Table 9. Mean porosity and saturation, and standard deviations for each hydrogeologic unit in for each borehole--Continued

[Por, porosity, SD, standard deviation; Sat, saturation; N, number of samples]

\begin{tabular}{|c|c|c|c|c|c|c|c|c|c|c|c|c|c|c|c|c|c|}
\hline Unit & & $\mathrm{N}-33$ & $\mathrm{~N}-34$ & $\mathrm{~N}-35$ & $\mathrm{~N}-36$ & $\mathrm{~N}=37$ & $\mathrm{~N}-38$ & N-53 & $\mathrm{N}-54$ & $\mathrm{~N}-55$ & $\mathrm{~N}-57$ & N-58 & N-59 & N-61 & $\mathrm{N}-62$ & $\mathrm{~N}-63$ & $\mathrm{~N}-64$ \\
\hline $\mathrm{TC}$ & $\begin{array}{l}\text { Mean por } \\
\text { SD Por } \\
\text { Mean Sat } \\
\text { SD Sat } \\
\text { N }\end{array}$ & & & & & $\begin{array}{l}0.03 \\
0.01 \\
0.62 \\
0.10 \\
7\end{array}$ & & $\begin{array}{l}0.05 \\
0.01 \\
0.66 \\
0.07 \\
2\end{array}$ & $\begin{array}{l}0.05 \\
0.00 \\
0.67 \\
0.00 \\
1\end{array}$ & $\begin{array}{l}0.06 \\
0.02 \\
0.70 \\
0.17 \\
7\end{array}$ & & & $\begin{array}{l}0.06 \\
0.00 \\
0.47 \\
0.07 \\
2\end{array}$ & $\begin{array}{l}0.06 \\
0.03 \\
0.64 \\
0.12 \\
7\end{array}$ & & & \\
\hline TR & $\begin{array}{l}\text { Mean por } \\
\text { SD Por } \\
\text { Mean Sat } \\
\text { SD Sat } \\
\text { N }\end{array}$ & & & & & & & & $\begin{array}{l}0.14 \\
0.01 \\
0.42 \\
0.15 \\
4\end{array}$ & & $\begin{array}{r}0.17 \\
0.03 \\
0.53 \\
0.08 \\
41\end{array}$ & $\begin{array}{c}0.16 \\
0.02 \\
0.51 \\
0.09 \\
30\end{array}$ & $\begin{array}{l}0.16 \\
0.03 \\
0.50 \\
0.12 \\
36\end{array}$ & $\begin{array}{l}0.17 \\
0.02 \\
0.48 \\
0.10 \\
30\end{array}$ & & & \\
\hline TUL & $\begin{array}{l}\text { Mean por } \\
\text { SD Por } \\
\text { Mean Sat } \\
\text { SD Sat } \\
\text { N }\end{array}$ & & & & & & & & & & $\begin{array}{l}0.16 \\
0.01 \\
0.60 \\
0.04 \\
3\end{array}$ & $\begin{array}{l}0.17 \\
0.02 \\
0.48 \\
0.13 \\
9\end{array}$ & $\begin{array}{l}0.18 \\
0.01 \\
0.60 \\
0.03 \\
3\end{array}$ & $\begin{array}{l}0.18 \\
0.02 \\
0.58 \\
0.10 \\
5\end{array}$ & & & \\
\hline TMNN & $\begin{array}{l}\text { Mean por } \\
\text { SD Por } \\
\text { Mean Sat } \\
\text { SD Sat } \\
\text { N }\end{array}$ & & & & & & & & & & & & & & & & \\
\hline TLL & $\begin{array}{l}\text { Mean por } \\
\text { SD Por } \\
\text { Mean Sat } \\
\text { SD Sat } \\
\text { N }\end{array}$ & & & & & & & & & & & & & & & & \\
\hline TM2 & $\begin{array}{l}\text { Mean por } \\
\text { SD Por } \\
\text { Mean Sat } \\
\text { SD Sat } \\
\text { N }\end{array}$ & & & & & & & & & & & & & & & & \\
\hline TMl & $\begin{array}{l}\text { Mean por } \\
\text { SD Por } \\
\text { Mean Sat } \\
\text { SD Sat } \\
\text { N }\end{array}$ & & & & & & & & & & & & & & & & \\
\hline PV3 & $\begin{array}{l}\text { Mean por } \\
\text { SD Por } \\
\text { Mean Sat } \\
\text { SD Sat } \\
\text { N }\end{array}$ & & & & & & & & & & & & & & & & \\
\hline PV2 & $\begin{array}{l}\text { Mean por } \\
\text { SD Por } \\
\text { Mean Sat } \\
\text { SD Sat } \\
\text { N }\end{array}$ & & & & & & & & & & & & & & & & \\
\hline BTI & $\begin{array}{l}\text { Mean por } \\
\text { SD Por } \\
\text { Mean Sat } \\
\text { SD Sat } \\
\text { N }\end{array}$ & & & & & & & & & & & & & & & & \\
\hline
\end{tabular}


Table 9. Mean porosity and saturation, and standard deviations for each hydrogeologic unit in for each borehole--Continued

[Por, porosity, SD, standard deviation; Sat, saturation; N, number of samples]

\begin{tabular}{|c|c|c|c|c|c|c|c|c|c|c|c|c|c|c|c|c|}
\hline Unit & & NRG-6 & NRG-7 & SD-12 & SD-7 & SD-9 & UZ 14 & UZ 16 & UZ 27a & $\mathrm{N}-11$ & $\mathrm{~N}-15$ & $\mathrm{~N}-16$ & $\mathrm{~N}-17$ & $\mathrm{~N}-27$ & $\mathrm{~N}-31$ & $\mathrm{~N}-32$ \\
\hline $\mathrm{CHV}$ & $\begin{array}{l}\text { Mean por } \\
\text { SD Por } \\
\text { Mean Sat } \\
\text { SD Sat } \\
\text { N }\end{array}$ & & & $\begin{array}{c}0.35 \\
0.04 \\
0.45 \\
0.23 \\
30\end{array}$ & $\begin{array}{l}0.34 \\
0.03 \\
0.45 \\
0.19 \\
31\end{array}$ & & & & & & & & & & & \\
\hline $\mathrm{CHZ}$ & $\begin{array}{l}\text { Mean por } \\
\text { SD Por } \\
\text { Mean Sat } \\
\text { SD Sat } \\
\text { N }\end{array}$ & & $\begin{array}{l}0.31 \\
0.02 \\
\\
4\end{array}$ & $\begin{array}{l}0.37 \\
0.03 \\
0.92 \\
0.12 \\
34\end{array}$ & $\begin{array}{c}0.35 \\
0.03 \\
0.92 \\
0.11 \\
21\end{array}$ & $\begin{array}{c}0.34 \\
0.03 \\
0.96 \\
0.04 \\
91\end{array}$ & $\begin{array}{l}0.32 \\
0.04 \\
1.00 \\
0.08 \\
68\end{array}$ & $\begin{array}{l}0.32 \\
0.04 \\
0.97 \\
0.03 \\
83\end{array}$ & & & & & & & & \\
\hline BT & $\begin{array}{l}\text { Mean por } \\
\text { SD Por } \\
\text { Mean Sat } \\
\text { SD Sat } \\
\text { N }\end{array}$ & & & $\begin{array}{l}0.26 \\
0.04 \\
1.03 \\
0.05 \\
12\end{array}$ & $\begin{array}{c}0.29 \\
0.05 \\
0.99 \\
0.03 \\
19\end{array}$ & $\begin{array}{c}0.26 \\
0.03 \\
1.00 \\
0.01 \\
17\end{array}$ & $\begin{array}{l}0.27 \\
0.03 \\
0.98 \\
0.01 \\
11\end{array}$ & $\begin{array}{l}0.25 \\
0.03 \\
0.98 \\
0.03 \\
10\end{array}$ & & & & & & & & \\
\hline PP4 & $\begin{array}{l}\text { Mean por } \\
\text { SD Por } \\
\text { Mean Sat } \\
\text { SD Sat } \\
\text { N }\end{array}$ & & & $\begin{array}{l}0.28 \\
0.01 \\
0.97 \\
0.02 \\
2\end{array}$ & $\begin{array}{l}0.33 \\
0.06 \\
0.90 \\
0.16 \\
10\end{array}$ & $\begin{array}{c}0.31 \\
0.03 \\
0.97 \\
0.01 \\
15\end{array}$ & $\begin{array}{l}0.34 \\
0.02 \\
0.95 \\
0.02 \\
16\end{array}$ & $\begin{array}{l}0.33 \\
0.07 \\
0.91 \\
0.05 \\
4\end{array}$ & & & & & & & & \\
\hline PP3 & $\begin{array}{l}\text { Mean por } \\
\text { SD Por } \\
\text { Mean Sat } \\
\text { SD Sat } \\
\text { N }\end{array}$ & & & $\begin{array}{c}0.32 \\
0.03 \\
0.44 \\
0.27 \\
34\end{array}$ & $\begin{array}{l}0.33 \\
0.02 \\
0.31 \\
0.16 \\
30\end{array}$ & $\begin{array}{c}0.33 \\
0.03 \\
0.95 \\
0.04 \\
22\end{array}$ & $\begin{array}{c}0.35 \\
0.02 \\
0.78 \\
0.18 \\
11\end{array}$ & $\begin{array}{r}0.30 \\
0.04 \\
0.42 \\
0.08 \\
21\end{array}$ & & & & & & & & \\
\hline PP2 & $\begin{array}{l}\text { Mean por } \\
\text { SD Por } \\
\text { Mean Sat } \\
\text { SD Sat } \\
\text { N }\end{array}$ & & & $\begin{array}{l}0.24 \\
0.05 \\
0.65 \\
0.24 \\
33\end{array}$ & $\begin{array}{c}0.20 \\
0.06 \\
0.63 \\
0.22 \\
31\end{array}$ & $\begin{array}{l}0.27 \\
0.02 \\
0.99 \\
0.02 \\
25\end{array}$ & $\begin{array}{c}0.31 \\
0.02 \\
0.96 \\
0.02 \\
12\end{array}$ & $\begin{array}{l}0.21 \\
0.04 \\
0.86 \\
0.14 \\
20\end{array}$ & & & & & & & & \\
\hline PP1 & $\begin{array}{l}\text { Mean por } \\
\text { SD Por } \\
\text { Mean Sat } \\
\text { SD Sat } \\
\text { N }\end{array}$ & & & $\begin{array}{l}0.30 \\
0.04 \\
1.02 \\
0.05 \\
98\end{array}$ & $\begin{array}{c}0.28 \\
0.06 \\
0.90 \\
0.10 \\
126\end{array}$ & $\begin{array}{l}0.30 \\
0.02 \\
0.99 \\
0.01 \\
69\end{array}$ & & $\begin{array}{l}0.20 \\
0.07 \\
0.96 \\
0.03 \\
19\end{array}$ & & & & & & & & \\
\hline BF3 & $\begin{array}{l}\text { Mean por } \\
\text { SD Por } \\
\text { Mean Sat } \\
\text { SD Sat } \\
\text { N }\end{array}$ & & & & $\begin{array}{l}0.12 \\
0.04 \\
0.98 \\
0.07 \\
86\end{array}$ & & & & & & & & & & & \\
\hline BF2 & $\begin{array}{l}\text { Mean por } \\
\text { SD Por } \\
\text { Mean Sat } \\
\text { SD Sat } \\
\text { N }\end{array}$ & & & & $\begin{array}{r}0.27 \\
0.07 \\
1.02 \\
0.04 \\
61\end{array}$ & & & & & & & & & & & \\
\hline
\end{tabular}


Table 9. Mean porosity and saturation, and standard deviations for each hydrogeologic unit in for each borehole--Continued

[Por, porosity, SD, standard deviation; Sat, saturation; N, number of samples]

\begin{tabular}{|c|c|c|c|c|c|c|c|c|c|c|c|c|c|c|c|c|c|}
\hline Unit & & $\mathrm{N}-33$ & $\mathrm{~N}-34$ & $\mathrm{~N}-35$ & $\mathrm{~N}-36$ & $\mathrm{~N}-37$ & $\mathrm{~N}-38$ & $\mathrm{~N}-53$ & $\mathrm{~N}-54$ & $\mathrm{~N}-55$ & $\mathrm{~N}-57$ & $\begin{array}{l}\mathrm{N}-58 \\
\end{array}$ & N-59 & $\mathrm{N}-61$ & $\mathrm{~N}-62$ & $\mathrm{~N}-63$ & $\mathrm{~N}-64$ \\
\hline CHV & $\begin{array}{l}\text { Mean por } \\
\text { SD Por } \\
\text { Mean Sat } \\
\text { SD Sat } \\
\text { N }\end{array}$ & & & & & & & & & & & & & & & & \\
\hline $\mathrm{CHZ}$ & $\begin{array}{l}\text { Mean por } \\
\text { SD Por } \\
\text { Mean Sat } \\
\text { SD Sat } \\
\text { N }\end{array}$ & & & & & & & & & & & & & & & & \\
\hline BT & $\begin{array}{l}\text { Mean por } \\
\text { SD Por } \\
\text { Mean Sat } \\
\text { SD Sat } \\
\text { N }\end{array}$ & & & & & & & & & & & & & & & & \\
\hline PP4 & $\begin{array}{l}\text { Mean por } \\
\text { SD Por } \\
\text { Mean Sat } \\
\text { SD Sat } \\
\text { N }\end{array}$ & & & & & & & & & & & & & & & & \\
\hline PP3 & $\begin{array}{l}\text { Mean por } \\
\text { SD Por } \\
\text { Mean Sat } \\
\text { SD Sat } \\
\text { N }\end{array}$ & & & & & & & & & & & & & & & & \\
\hline PP2 & $\begin{array}{l}\text { Mean por } \\
\text { SD Por } \\
\text { Mean Sat } \\
\text { SD Sat } \\
\text { N }\end{array}$ & & & & & & & & & & & & & & & & \\
\hline PPI & $\begin{array}{l}\text { Mean por } \\
\text { SD Por } \\
\text { Mean Sat } \\
\text { SD Sat } \\
\text { N }\end{array}$ & & & & & & & & & & & & & & & & \\
\hline $\mathrm{BF} 3$ & $\begin{array}{l}\text { Mean por } \\
\text { SD Por } \\
\text { Mean Sat } \\
\text { SD Sat } \\
\text { N }\end{array}$ & & & & & & & & & & & & & & & & \\
\hline $\mathrm{BF} 2$ & $\begin{array}{l}\text { Mean por } \\
\text { SD Por } \\
\text { Mean Sat } \\
\text { SD Sat } \\
\text { N }\end{array}$ & & & & & & & & & & & & & & & & \\
\hline
\end{tabular}


to show different trends based on depositional mechanisms (pyroclastic flow or fallout deposits, for example), but a study near the base of the Tiva Canyon Tuff, which examined the Tpcplnc (moderately welded), Tpcpv2, Tpcpv1, and Tpbt4 units along an exposure over $1 \mathrm{~km}$ long, showed little evidence of lateral trends in properties at any stratigraphic position within these four units (Istok and others, 1994; Rautman and others, 1995), at least on the scale of the study, from Yucca Wash to Busted Butte. The Yucca Mountain and Pah Canyon Tuffs do not vary significantly across the potential repository location, but become increasingly welded to the north where the samples are very limited. The zeolitized rocks of the Calico Hills Formation also do not vary substantially in hydrologic properties over lateral distances up to $3 \mathrm{~km}$ (Rautman, 1991). Saturation is far more spatially variable and is included for information only and in table 8 as initial conditions.

\section{SUMMARY}

Measured values of rock core porosity, saturated hydraulic conductivity, moisture-retention characteristics, and saturation, along with lithostratigraphic descriptions, were used to divide the unsaturated zone at Yucca Mountain into 30 discrete hydrogeologic units that can be related to the existing three-dimensional lithostratigraphic models. These units, with some exceptions in the Prow Pass and Bullfrog Tuffs, are intended to be hydrologically similar and distinct enough to be used successfully to design large- and small-scale numerical models to describe water flow at Yucca Mountain. Mean values and standard deviations of bulk density, porosity, particle density, saturation, water potential, and saturated hydraulic conductivity are provided for each hydrogeologic unit, as well as representative values of van Genuchten moistureretention curve-fit parameters, $\alpha$ and $n$, and residual saturation.

Porosity was the most useful property in characterizing individual hydrogeologic units because it was measured on the most samples, and it is well correlated to saturated hydraulic conductivity and the moistureretention curve-fit parameter, $\alpha$. Several additional features played an important part in the hydrogeologicunit development. Zones of mineral alteration, especially at the base of the Tiva Canyon Tuff and the zeolitized rocks below the Topopah Spring Tuff, have a substantial influence on the storage and transmission of water. The close spatial sampling through many units helped define two types of boundaries between units: transition zones where properties change dramatically but smoothly over short vertical distances, such as at the top of the PTn, and abrupt changes in properties, such as at the bottom of the PTn. These two types of boundaries are of particular interest because of the possibility of capillary or permeability barriers. Zones of variably developed vapor-phase corrosion are characterized individually on the basis of changes in porosity. To develop functions that could be used to further discretize models in zones where properties change across short distances, the relation of porosity to saturated hydraulic conductivity and $\alpha$ was analyzed. As a result, hydrologic properties specific to the volcanic rocks at Yucca Mountain were characterized to provide modeling parameters representing all significant hydrogeologic units in the unsaturated zone.

\section{REFERENCES}

American Society of Testing Materials, 1977, Adsorption and bulk specific gravity of natural building stone: American Society of Testing Materials, ANSI/ASTM R97-47, Annual Book of ASTM Standards, Part 19, $472 \mathrm{p}$.

Anderson, L.A., 1981a, Rock property analysis of core samples from the Calico Hills UE25a-3 borehole, Nevada Test Site, Nevada: U.S. Geological Survey Open-File Report 81-1337, 30 p.

Anderson, L.A., 1981b, Rock property analysis of core samples from the Yucca Mountain UE25a-1 borehole, Nevada Test Site, Nevada: U.S. Geological Survey Open-File Report 81-1338, 31 p.

Anderson, L.A., 1984, Rock property measurements on large-volume core samples from Yucca Mountain USW GU-3/G-3 and USW G- 4 boreholes, Nevada Test Site, Nevada: U.S. Geological Survey Open-File Report 84-552, 39 p.

Anderson, L.A., 1991, Results of rock property measurements made on core samples from Yucca Mountain boreholes, Nevada Test Site, Nevada_Part 1, Boreholes UE25A-4, -5, -6, and 7; part 2, Borehole UE25p\#1: U.S. Geological Survey Open-File Report 90-474, $47 \mathrm{p}$.

Bish, D.L., 1989, Evaluation of past and future alterations in tuff at Yucca Mountain, Nevada, based on the clay mineralogy of drill cores USW G-1, G-2, and G-3: Los Alamos National Laboratory Report LA-10677-MS, $40 \mathrm{p}$. 
Bish, D.L., and Aronson, J.L., 1993, Paleogeothermal and paleohydrologic conditions in silicic tuff from Yucca Mountain: Clays and Clay Minerals, v. 41, no. 2, p. 14-161.

Bish, D.L., and Chipera, S.J., 1989, Revised mineralogic summary of Yucca Mountain, Nevada: Los Alamos National Laboratory Report LA-11497-MS, 68 p.

Broxton, D.E., Bish, D.L., and Warren, R.G., 1987, Distribution and chemistry of diagenetic minerals at Yucca Mountain, Nye County, Nevada: Clays and Clay Minerals, v. 35, no. 2, p. 89-110.

Buesch, D.C., Nelson, J.E., Dickerson, R.P., Drake, R.M., Spengler, R.W., Geslin, J.K., Moyer, R.C., and San Juan, C.A., 1996a, Distribution of lithostratigraphic units within the central block of Yucca Mountain, Nevada - A three-dimensional computer-based model, version YMP.R2.0: U.S. Geological Survey Open-File Report 95-124, 61 p.

Buesch, D.C., Spengler, R.W., Moyer, T.C., and Geslin, J.K., 1996b, Proposed stratigraphic nomenclature and macroscopic identification of lithostratigraphic units of the Paintbrush Group exposed at Yucca Mountain, Nevada: U.S. Geological Survey Open-File Report 94-469, $47 \mathrm{p}$.

Buesch, D.C., Spengler, R.W., Nelson, P.H., Vaniman, D.R., Chipera, S.J., and Bish, D.L., 1995, Geometry of the vitric-zeolitic transition in tuffs and the relation to fault zones at Yucca Mountain Nevada [abs.]: International Union of Geodesy and Geophysics, XXI General Assembly, Boulder, Colo., Abstracts Week A, p. A426.

Bush, D.C., and Jenkins, R.E., 1970, Proper hydration of clays for rock property determinations: Journal of Petroleum Technology, v. 22, no. 7, p. 800-804.

Byers, F.M., Jr., Carr, W.J., Orkild, P.P., Quinlivan, W.D., and Sargent, K.A., 1976, Volcanic suites and related cauldrons of the Timber Mountain-Oasis Valley Caldera Complex, southern Nevada: U.S. Geological Survey Professional Paper 919, 70 p.

Carr, W.J., Byers, F.M., Jr., and Orkild, P.P., 1986, Stratigraphic and volcano-tectonic relations of the Crater Flat Tuff and some older volcanic units, Nye County, Nevada: U.S. Geological Survey Professional Paper $1323,28 \mathrm{p}$.

Chipera, S.J., Vaniman, D.T., Carlos, B.A., and Bish, D.L., 1994, Mineralogic variation in drill core UE-26 UZ \#16, Yucca Mountain, Nevada: Los Alamos National Laboratory Report LA-12878-MS, 40 p.

Deer, W.A., Howie, R.A., and Zussman, J., 1966, An Introduction to the rock-forming minerals: New York, Wiley, p. 264-269.
Deutsch, C.V., 1989, Calculating effective absolute permeability in sandstone/shale sequences: SPE Formation Evaluation, v. 4, p. 343-348.

Diehl, S.F., and Chornack, M.P., 1990, Stratigraphic correlation and petrography of the bedded tuffs, Yucca Mountain, Nye County, Nevada: U.S. Geological Survey Open-File Report 89-3, 152 p.

Engstrom, D.A., and Rautman, C.A., 1996, Geology of the USW SD-9 drill hole, Yucca Mountain, Nevada: Albuquerque, N. Mex., Sandia National Laboratories Yucca Mountain Project Report SLTR96-0002, 148 p.

Flint, A.L., and Flint, L.E., 1994, Spatial distribution of potential near surface moisture flux at Yucca Mountain: International High-Level Radioactive Waste Conference, Las Vegas, Nev., May 2-26, 1994, Proceedings, $7 \mathrm{p}$.

Flint, A.L., Flint, L.E., and Hevesi, J.A., 1993, Influence of long term climate change on net infiltration at Yucca Mountain, Nevada: International High-Level Radioactive Waste Conference, Las Vegas, Nev., April 25-30, 1993, Proceedings, 12 p.

Flint, L.E., and Flint, A.L., 1990, Preliminary permeability and moisture retention of nonwelded and bedded tuffs at Yucca Mountain, Nevada: U.S. Geological Survey Open-File Report 90-569, 57 p.

Flint, L.E., and Flint, A.L., 1995, Shallow infiltration processes at Yucca Mountain, Nevada-Neutron logging data 1984-93: U.S. Geological Survey WaterResources Investigations Report 95-4035, 46 p.

Flint, L.E., Flint, A.L., Moyer, T.C., and Geslin, J.K., 1996a, Lateral diversion of water in the Paintbrush Tuff nonwelded hydrologic unit, Yucca Mountain, Nevada: EOS, American Geophysical Union Proceedings, Fall meetings, 1996.

Flint, L.E., Flint, A.L., Rautman, C.A., and Istok, J.D., 1996b, Physical and hydrologic properties of rock outcrop samples at Yucca Mountain, Nevada: U.S. Geological Survey Open-File Report 95-280, 70 p.

Gardner, W.H., 1965, Water content, in Black, C.A., ed., Methods of soil analysis, part I,: Madison, Wis., American Society of Agronomy, Inc., p. 82-127.

Geslin, J.K., and Moyer, T.C., 1995, Summary of lithologic logging of new and existing boreholes at Yucca Mountain, Nevada, March 1994 to June 1994: U.S. Geological Survey Open-File Report 94 451, 16 p.

Geslin, J.K., Moyer, T.C., and Buesch, D.C., 1995, Summary of lithologic logging of new and existing boreholes at Yucca Mountain, Nevada, August 1993 to February 1994: U.S. Geological Survey Open-File Report 94-342, 39 p. 
Glass, R.J., Flint, A.L., Tidwell, V.C., Peplinski, W., and Castro, Y., 1994, Fracture-matrix interaction in Topopah Spring tuff-Experiment and numerical simulation: International High-Level Radioactive Waste Conference, Las Vegas, Nev., May 22-26, 1994, Proceedings, $9 \mathrm{p}$.

Grayson, D.K., 1993, The desert's past-A natural prehistory of the Great Basin: Washington D.C., Smithsonian Institution Press, $356 \mathrm{p}$.

Hammermeister, D.P., Blout, D.O., and McDaniel, J.C., 1985, Drilling and coring methods that minimize the disturbance of cuttings, core and rock formation in the unsaturated zone, Yucca Mountain, Nevada: National Water Well Association, Proceedings of the National Water Well Association Conference on Characterization and Monitoring of the Vadose (Unsaturated) Zone, p. 507-541.

Hillel, D., and Baker, R.S., 1988, A descriptive theory of fingering during infiltration into layered soils: Soil Science, v. 146, p. 51-56.

Istok, J.D., Rautman, C.A., Flint, L.E., and Flint, A.L., 1994, Spatial variability in hydrologic properties of a volcanic tuff: Ground Water, v. 32, no. 5, p. 751-760.

Iwata, S., Tabuchi, T., and Warkentin, B.P., 1988, Soil-water interactions: New York, Marcel Dekker, Inc., p. 155-164.

Jackson, R.D., 1964, Water vapor diffusion in relatively dry soil-III, Steady-state experiments: Soil Science Society of America Proceedings, v. 28, p. 467-470.

Jensen, J.L., 1991, Use of the geometric average for effective permeability estimation: Mathematical Geology, v. 23, p. 833-840.

Journel, A.G., Deutsch, C.V., and Desbarats, A.J., 1986, Power averaging for block effective permeability: Richardson, Tex., Society of Petroleum Engineers, 54th California Regional Meeting, Oakland, Calif, SPE Paper 15128, p. 329-334.

Klavetter, E.A., and Peters, R.R., 1987, An evaluation of the use of mercury porosimetry in calculating hydrologic properties of tuffs from Yucca Mountain, Nevada: Albuquerque, N. Mex., Sandia National Laboratories Report SAND86-0286, 74 p.

Kume, Jack, and Hammermeister, D.P., 1990, Geohydrologic data from test hole USW UZ-7, Yucca Mountain area, Nye County, Nevada: U.S. Geological Survey Open-File Report 88-465, 46 p.

Levy, S.S., 1984, Studies of altered vitrophyre for the prediction of nuclear waste repository-induced thermal alteration at Yucca Mountain, Nevada, in McVay, G.L., ed., Scientific basis for nuclear waste management: Elsevier, New York, Proceedings of the 7th Material Research Society Symposium, p. 959-966.
Levy, S.S., Norman, D.I., and Chipera, S.J., 1996, Alteration history studies in the Exploratory Studies Facility, Yucca Mountain, Nevada, USA, in Murphy, W., and Knecht, D., eds., Scientific Basis for Nuclear Waste Management XIX: Pittsburgh, Pa., Materials Research Society, p. 543-548.

Loskot, C.L., 1993, Geohydrologic data from test hole USW UZ-6s, Yucca Mountain, Nye County, Nevada: U.S. Geological Survey Open-File Report 93-60, 25 p.

Loskot, C.L., and Hammermeister, D.P., 1992, Geohydrologic data from test holes UE-25 UZ \#4 and UE-25 UZ \#5, Yucca Mountain area, Nye County, Nevada: U.S. Geological Survey Open-File Report 90-369, $56 \mathrm{p}$.

Martin, J.W., Felice, C.W., DeVan, R.T., and Green, S.J., 1991, Grain density measurements on zeolitized tuff: Symposium on Containment of Underground Nuclear Explosions, 6th University of Nevada, Reno, Nev., Sept. 24-27, 1991, Proceedings, 12 p.

McKenna, S.A., and Rautman, C.A., 1996, Scaling of properties for Yucca Mountai- Literature review and numerical experiments on saturated hydraulic conductivity: Albuquerque, N. Mex., Sandia National Laboratories Report SAND95-2338, $117 \mathrm{p}$.

Montazer, Parviz, and Wilson, W.E., 1984, Conceptual hydrologic model of flow in the unsaturated zone, Yucca Mountain, Nevada: U.S. Geological Survey Water-Resources Investigation Report 84-4345, $55 \mathrm{p}$.

Moyer, T.C., and Geslin, J.K., 1995, Lithostratigraphy of the Calico Hills Formation and Prow Pass Tuff (Crater Flat Group) at Yucca Mountain, Nevada: U.S. Geological Survey Open-File Report 94-460, 59 p.

Moyer, T.C., Geslin, J.K., and Buesch, D.C.,1995, Summary of lithologic logging of new and existing boreholes at Yucca Mountain, Nevada, July 1994 to November 1994: U.S. Geological Survey Open-File Report 94-451, $22 \mathrm{p}$.

Moyer, T.C., Geslin, J.K., and Flint, L.E., 1996, Stratigraphic relations and hydrologic properties of the Paintbrush Tuff nonwelded (PTn) hydrologic unit, Yucca Mountain, Nevada: U.S. Geological Survey Open-File Report 95-397, $151 \mathrm{p}$.

Nelson, P.H., 1994, Saturation levels and trends in the unsaturated zone, Yucca Mountain, Nevada: American Nuclear Society, Proceedings, International High-Level Radioactive Waste Management Conference, v. 1, p. $949-954$.

Nelson, P.H., Muller, D.C., Schimschal, U., and Kilber, J.E., 1991, Geophysical logs and core measurements from forty boreholes at Yucca Mountain, Nevada: U.S. Geological Survey Geophysical Investigations Map GP-1001, 64 p. 
Nutting, P.G., 1943, Some standard thermal dehydration curves of minerals: U.S. Geological Survey Professional Paper 197-E, 28 p.

Oldenburg, C.M., and Pruess, K., 1993, On numerical modeling of capillary barriers: Water Resources Research, v. 29 , no. 4 , p. $1045-1056$.

Peters, R.R., Klavetter, E.A., George, J.R., and Gauthier, J.H., 1987, Measuring and modeling water imbibition into tuff, in Evans, D.D., and Nicholson, R.H., eds., Flow and transport through unsaturated fractured rock: Washington, D.C., American Geophysical Union, Geophysical Monograph 42, p. 99-106.

Peters, R.R., Klavetter, E.A., Hall, I.J., Blair, S.C., Heller, P.R., and Gee, G.W., 1984, Fracture and matrix hydrogeologic characteristics of tuffaceous materials from Yucca Mountain, Nye County, Nevada: Albuquerque, N. Mex., Sandia National Laboratories Report SAND84-1471, $108 \mathrm{p}$.

Rautman, C.A., 1991, Estimates of spatial correlation in volcanic tuff, Yucca Mountain, Nevada: Albuquerque, N. Mex., Sandia National Laboratory Report SAND89-2270, $117 \mathrm{p}$.

Rautman, C.A., 1995, Preliminary geostatistical modeling of thermal conductivity for a cross section of Yucca Mountain, Nevada: Albuquerque, N. Mex., Sandia National Laboratories Report SAND95-2283, $50 \mathrm{p}$.

Rautman, C.A., and Engstrom, D.A., 1996a, Geology of the USW SD-7 drill hole, Yucca Mountain, Nevada: Albuquerque, N. Mex., Sandia National Laboratories Yucca Mountain Project Report SAND96-1474, 164 p.

Rautman, C.A., and Engstrom, D.A., 1996b, Geology of the USW SD-12 drill hole, Yucca Mountain, Nevada: Albuquerque, N. Mex., Sandia National Laboratories Yucca Mountain Project Report SAND96-1368, 132 p.

Rautman, C.A., and Flint, A.L., 1992, Deterministic processes and stochastic modeling, in Proceedings, 2nd Annual International High-Level Radioactive-Waste Management Conference; La Grande Park, Ill., American Nuclear Society, v. 2, p. 1617-1624.

Rautman, C.A., Flint, L.E., Flint, A.L., and Istok, J.D., 1995, Physical and hydrologic properties of outcrop samples from a nonwelded to welded tuff transition, Yucca Mountain, Nevada: U.S. Geological Survey Open-File Report 95-4061, 28 p.

Riehle, J.R., Miller, R.F., and Bailey, R.A., 1995, Cooling, degassing and compaction of rhyolitic ash flow tuffA computational model: Bulletin of Volcanology, v. 57, no. 5, p. 319-336.
Rose, D.A., 1963, Water movement in porous materialsPart 2, The separation of the components of water movement: British Journal Applied Physics, v. 14, p. 491-496.

Ross, Benjamin., 1990, The diversion capacity of capillary barriers: Water Resources Research, v. 26, no. 10, p. 2625-2629.

Rush, F.E., Thordarson, William, and Bruckheimer, L., 1983, Geohydrologic and drill-hole data for test well USW H-1, adjacent to the Nevada Test Site, Nye County, Nevada: U.S. Geological Survey Open-File Report 83-141, $68 \mathrm{p}$.

Sawyer, D.A., Fleck, R.J., Lanphere, M.A., Warren, R.G., and Broxton, D.E., 1994, Episodic volcanism in the Miocene southwest Nevada volcanic field-Stratigraphic revisions, ${ }^{40} \mathrm{Ar} /{ }^{39} \mathrm{Ar}$ geochronologic framework, and implications for magmatic evolution: Geological Society of America Bulletin, v. 106, no. 10, p. 1304-1318.

Schenker, A.R., Guerin, D.C., Robey, T.H., Rautman, C.A., and Barnard, R.W., 1995, Stochastic hydrogeologic units and hydrogeologic properties development for total-system performance assessments: Albuquerque, N. Mex., Sandia National Laboratories Report SAND94-0244, $165 \mathrm{p}$.

Scott, R.B., and Bonk, Jerry, 1984, Preliminary geologic map of Yucca Mountain with geologic sections, Nye County, Nevada: U.S. Geological Survey Open-File Report 84-494, scale 1:12,000.

Scott, R.B., Spengler, R.W., Diehl, S., Lappin, A.R., and Chornack, M.P., 1983, Geologic character of tuffs in the unsaturated zone at Yucca Mountain, southern Nevada, in Mercer, J.W., Rao, P.S.C., and Marine, I.W., eds., Role of the unsaturated zone in radioactive and hazardous waste disposal: Ann Arbor, Mich., Ann Arbor Science, p. 289-335.

Smith, R.L., 1960a, Ash flows: Geological Society of America Bulletin, v. 71, p. 795-842.

Smith, R.L., 1960b, Zones and zonal variations in welded tuffs: U.S. Geological Survey Professional Paper 354-F, p. 149-159.

Snyder, D.B., and Carr, W.J., 1982, Preliminary results of gravity investigations at Yucca Mountain and vicinity, southern Nye County, Nevada: U.S. Geological Survey Open-File Report 82-701, 36 p.

Steenhuis, T.S., Kung, K.-J.S., Parlange, J.-Y., Selker, J.S. and Chen, X.-X., 1990, Flow regimes in sandy soils with inclined layers: Annual Hydrology Days, American Geophysical Union, 10th, Fort Collins, Colo., April 10-12, 1990, Proceedings, $10 \mathrm{p}$. 
Thordarson, William, Rush, F.E., Spengler, R.W., and Wadell, S.J., 1984, Geohydrologic and drill-hole data for test well USW H-3, Yucca Mountain Nye County, Nevada: U.S. Geological Survey Open-File Report 84-149, $21 \mathrm{p}$.

TRW, 1995, Total system performance assessment - 1995An evaluation of the potential Yucca Mountain Repository: Las Vegas, Nev., TRW Environmental Safety Systems, B00000000-01717-2200-00136.

van Genuchten, M.Th., 1980, A closed-form equation for predicting the hydraulic conductivity of unsaturated soils: Soil Science Society of America Journal, v. 44, p. 892-898.

van Genuchten, M.Th., Leij, F.J., and Yates, S.R., 1991, The RETC code for quantifying hydraulic functions of unsaturated soils: U.S. Environmental Protection Agency Report EPA/600/2-91/065, 93 p.

Weeks, E.P., and Wilson, W.E., 1984, Preliminary evaluation of hydrologic properties of cores of unsaturated tuff, test well USW H-1, Yucca Mountain, Nevada: U.S. Geological Survey Water-Resources Investigations Report 84-4193, $30 \mathrm{p}$.

Whitfield, M.S., Jr., Cope, C.M., and Loskot, C.L., 1993, Borehole and geohydrologic data for test hole USW UZ-6, Yucca Mountain area, Nye County, Nevada: U.S. Geological Survey Open-File Report 92-28, 41 p.

Whitfield, M.S., Jr., Thordarson, William, and Eshom, E.P., 1984, Geohydrologic and drill-hole data for test well USW H-4, Yucca Mountain, Nye County, Nevada: U.S. Geological Survey Open-File Report 84-449, $20 \mathrm{p}$.

Wittwer, C.S., Bodvarsson, G.S., Chornack, M.P., Flint, A.L., Flint, L.E., Lewis, B.D., Spengler, R.W., and Rautman, C.A., 1992, Design of a three-dimensional site-scale model for the unsaturated zone at Yucca Mountain, Nevada: International High-Level Radioactive Waste Conference, Las Vegas, Nev., April 12-16, 1992, Proceedings, p. 263-271. 


\section{APPENDIX: FREQUENCY DISTRIBUTIONS OF POROSITY FOR HYDROLGEOLOGIC UNITS}



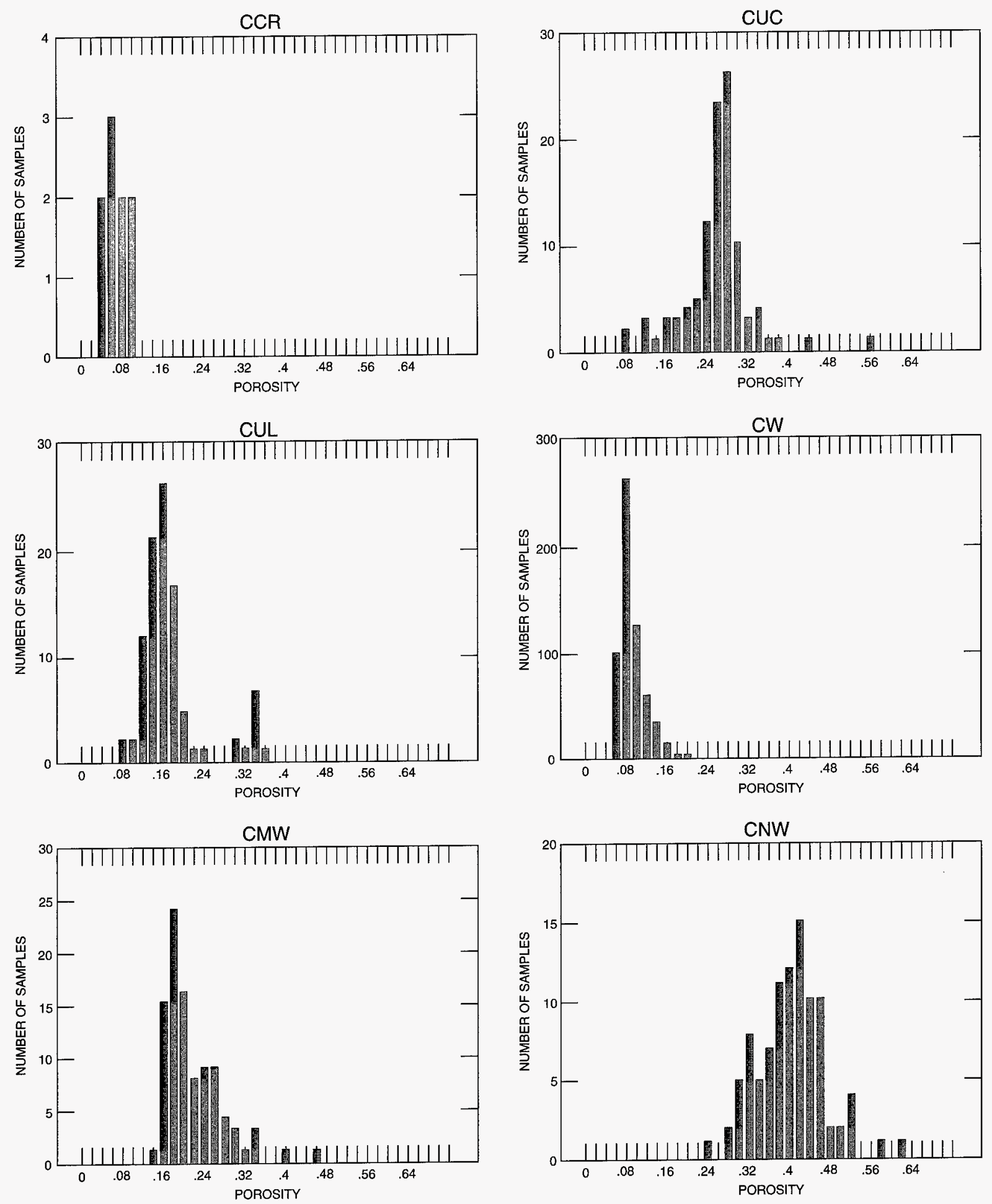

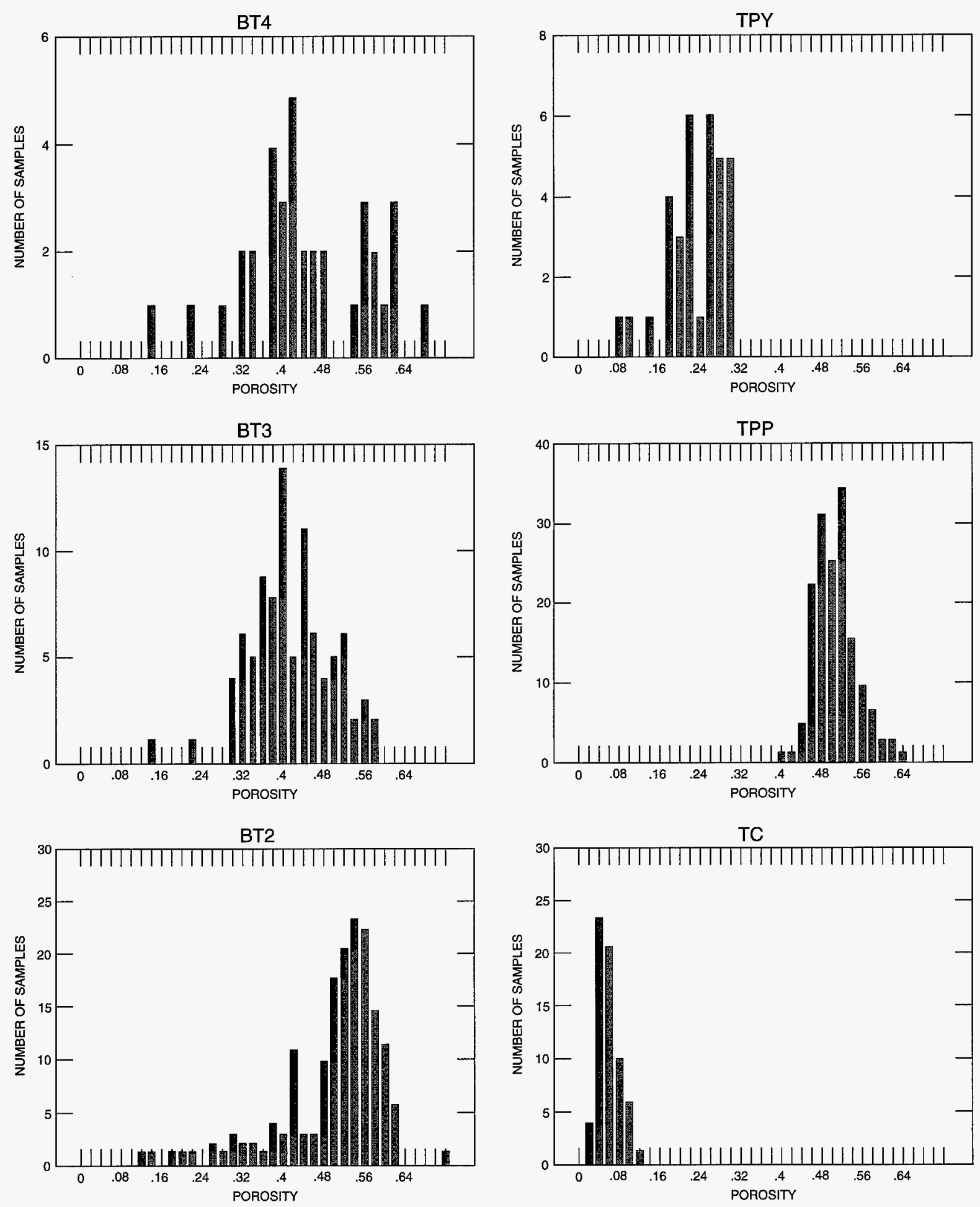

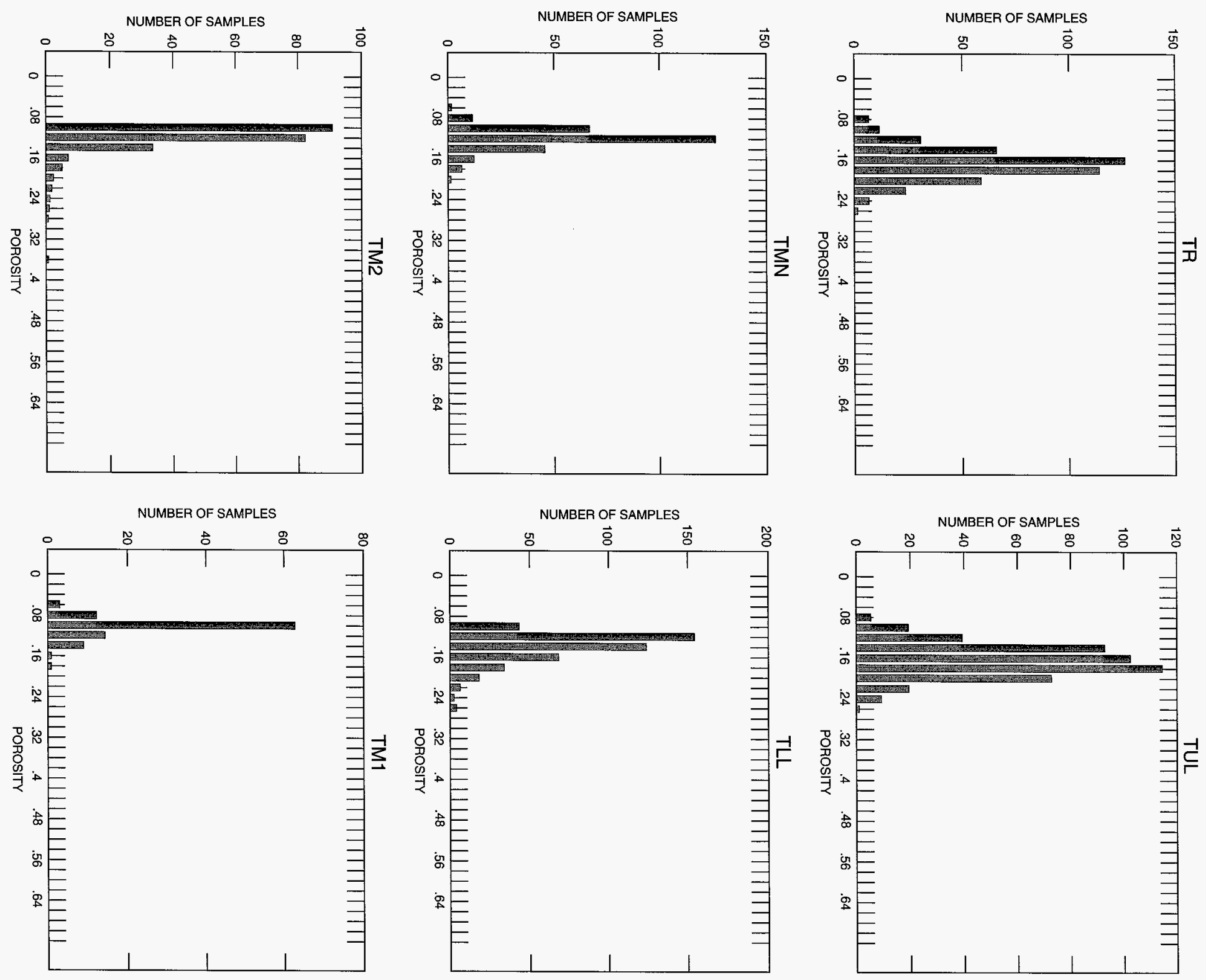

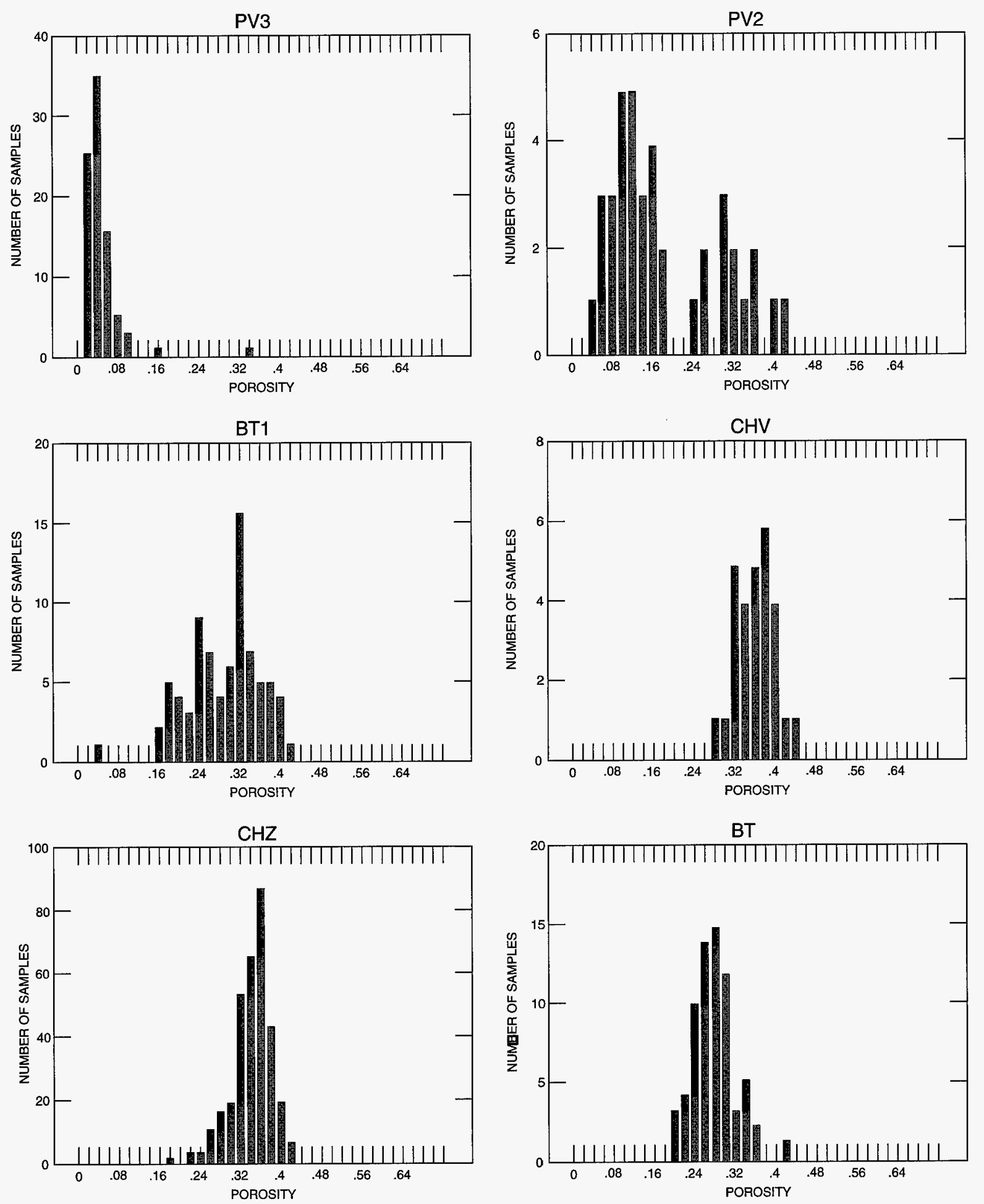
8

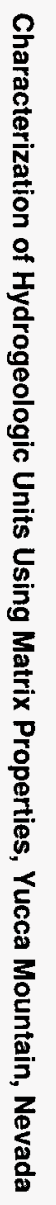
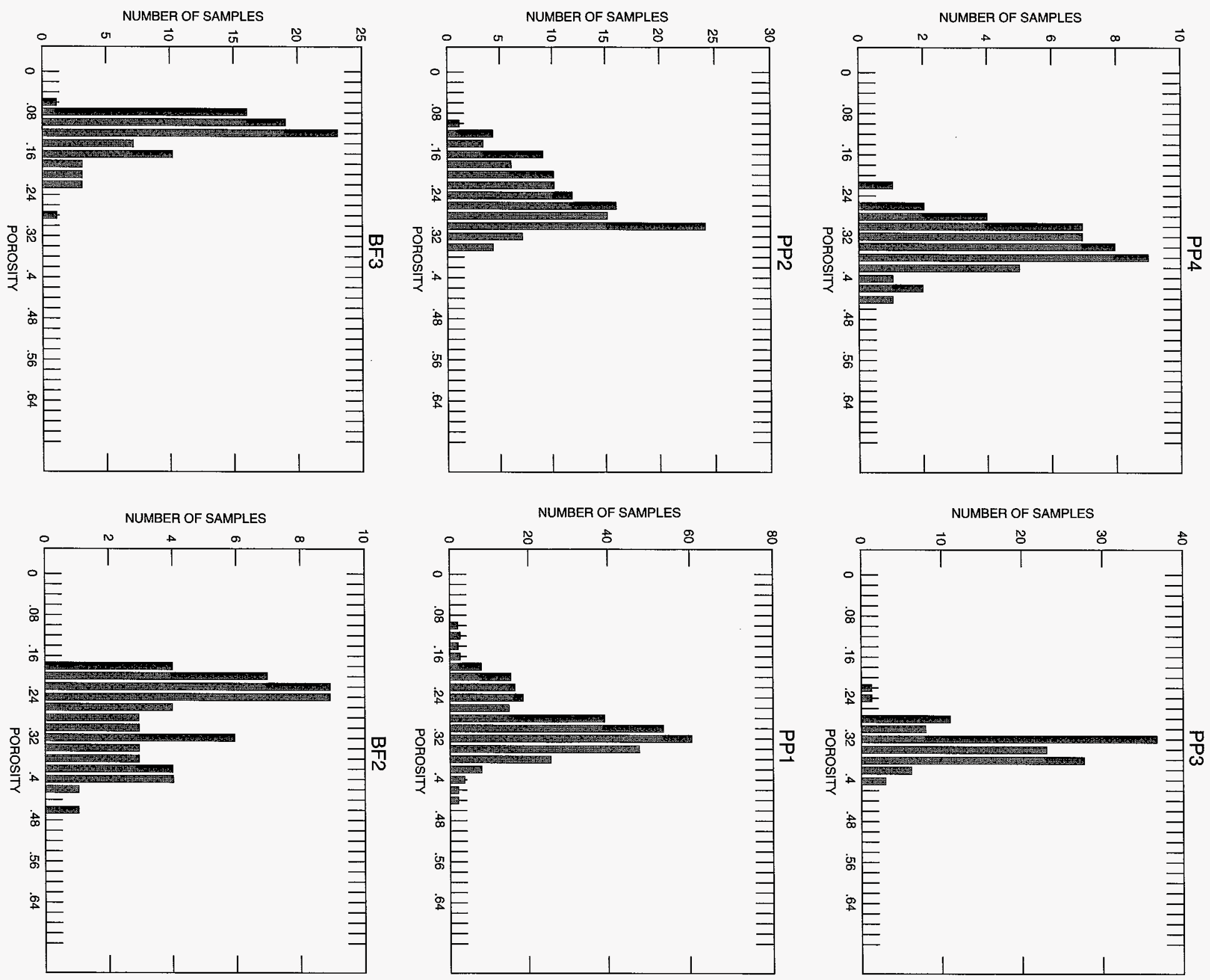


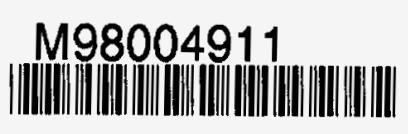

Report Number (14) $\frac{(\$ 565 / \omega R I R--}{97-4243}$

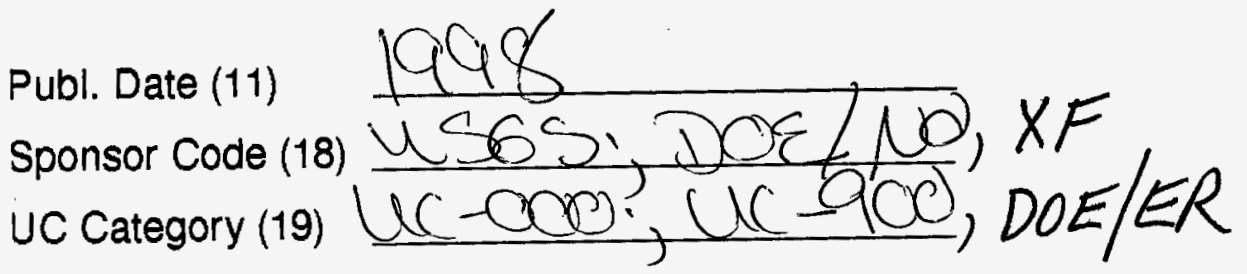

